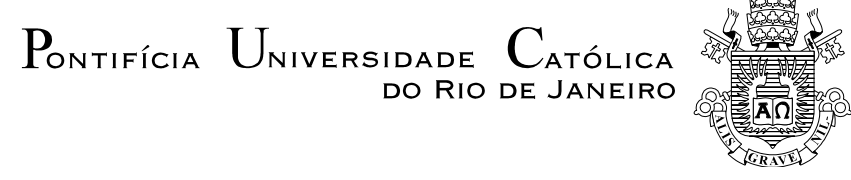

Mariana Leiras Rede Socioassistencial para Egressos
do Sistema Penitenciário:
desafios em sua construção

Dissertação apresentada como requisito parcial para obtenção do título de Mestre pelo Programa de Pós-Graduação em Serviço Social do Departamento de Serviço Social da PUC-Rio.

Orientador: Prof. Marcio Eduardo Brotto 
Mariana Leiras

\title{
Rede Socioassistencial para Egressos do Sistema Penitenciário: desafios em sua construção
}

\begin{abstract}
Dissertação apresentada como requisito parcial para obtenção do grau de Mestre pelo Programa de Pós-Graduação em Serviço Social do Departamento de Serviço Social do Centro de Ciências Sociais da PUC-Rio. Aprovada pela Comissão Examinadora abaixo assinada.
\end{abstract}

Prof. Marcio Eduardo Brotto

Orientador

Departamento de Serviço Social - PUC-Rio

Profa. Lobelia da Silva Faceira

UNIRIO

Profa. Ebe Campinha dos Santos Universidade do Grande Rio

Prof ${ }^{a}$. Sindely Chahim de Avellar Alchorme Prefeitura da Cidade do Rio de Janeiro

Profa. Mônica Herz

Vice-Decana de Pós-Graduação do Centro de Ciências Sociais - PUCC-Rio

Rio de Janeiro, 24 de agosto de 2015 
Todos os direitos reservados. É proibida a reprodução total ou parcial do trabalho sem a autorização da universidade, do autor e do orientador

\section{Mariana Leiras}

Graduou-se em Serviço Social pela Pontifícia Universidade Católica do Rio de Janeiro, em 2007, onde atua em parceria como supervisor de estágio do Departamento de Serviço Social (2008 a 2015). Especializou-se em Gestão de QSMS e Sustentabilidade pela Universidade Católica de Petrópolis (UCP) em 2011. Trabalha como assistente social e coordenadora de Projeto, no Banco da Providência - com a inserção social de internos e egressos do sistema penitenciário, na sociedade, pela via de capacitação profissional e do trabalho, desde agosto de 2007.

Ficha Catalográfica

Leiras, Mariana

Rede socioassistencial para egressos do sistema penitenciário: desafios em sua construção / Mariana Leiras; orientador: Marcio Eduardo Brotto. $-2015$.

123f.: il. (color.); $30 \mathrm{~cm}$

Dissertação (mestrado)-Pontifícia Universidade Católica do Rio de Janeiro, Departamento de Serviço Social, 2015.

Inclui bibliografia.

1. Serviço social - Teses. 2. Assistência social. 3. Egressos. 4. Inserção social. 5. Rede socioassistencial. 6. Sistema penitenciário. I. Brotto, Marcio Eduardo. II. Pontifícia Universidade Católica do Rio de Janeiro. Departamento de Serviço Social. III. Título. 


\section{Agradecimentos}

A Deus, pela vida e por tudo que tem acontecido nela.

À PUC por me conceder além da bolsa de estudo, a realização de um sonho.

Aos meus pais, Maria e Walter e irmãs, Fabiana e Adriana Leiras, que sempre me apoiaram e incentivaram.

Aos meus queridos sobrinhos: Bianca, Patric e Beatriz Leiras Alonso, que vocês sejam profissionais responsáveis e pessoas amigas e amáveis.

Ao meu orientador, Marcio Eduardo Brotto, pela sua paciência e orientação que tornaram possível a realização deste trabalho. 
Aos Doutores, Lobelia da Silva Faceira (minha querida co-orientadora), Maria Augusta da Silva Tavares e Marcelo Luciano Vieira, pelo exemplo de profissionais e de pessoas generosas que são.

Aos professores, do departamento de Serviço Social com os quais tive contato durante estes dois anos de mestrado. Em especial, a professora Luiza Helena Nunes Ermel, incentivadora de sonhos...

Aos funcionários do departamento de Serviço Social pela atenção e colaboração. Especialmente, a querida Joana.

A todos os colegas de mestrado, destaco: Vera, Renato, Regina e Haide, que sempre me deram força nos trabalhos e com palavras de apoio.

Aos membros da Rede de Apoio ao Egresso do Sistema Penitenciário - RAESP: Silvia, Sidney, Edite, Mariangela, Miralda, Brasileiro, Amora, Erica, Vanusa, Sandra, Mário, Jayvanne, Célia, Adenice, Marilena, Elizabeth, Angela, Maxoel, Edson e Jerry, obrigada pela participação e colaboração neste trabalho. A luta continua companheiros!!!!!

A equipe do Banco da Providência: Jocilene, Vânia, Márcia, Wilma, Edna, Neige e Ana Paula. Instituição onde atuo como Assistente Social e Coordenadora de Projeto e que me proporcionou a participação na referida Rede, e de exercer a prática junto aos internos e egressos do Sistema Penitenciário. Em especial a Gerente de Projetos, Terezinha Nascimento, pela compreensão, apoio e parceria, nesses 10 anos.

A todos os amigos que de uma forma ou de outra me estimularam ou me ajudaram na conquista deste sonho. As minhas amigas, Marlucia Avellar e Marcelle Marins, pelo apoio na revisão desse trabalho.

Aos meus ex estagiários, Alice, Vagner, Vanda, Débora e Gilmara, as minhas estagiárias, Joelma, Silvonete e Fátima, por toda força e incentivo. 


\section{Resumo}

Leiras, Mariana; Brotto, Marcio Eduardo. Rede socioassistencial para egressos do sistema penitenciário: desafios em sua construção. Rio de Janeiro, 2015. 123p. Dissertação de Mestrado - Departamento de Serviço Social, Pontifícia Universidade Católica do Rio de Janeiro.

A presente dissertação tem como foco os processos de organização da Rede Socioassistencial voltada para o atendimento a egressos do sistema penitenciário. A necessidade de analisar os processos de organização da Rede, surgiu a partir da inserção na Rede de Apoio ao Egresso do Sistema Penitenciário (RAESP), que tem como objetivo, integrar ações para promover a cidadania dos egressos do sistema penitenciário. Para tanto, realizamos um levantamento de iniciativas no município do Rio de Janeiro, vinculadas as instituições públicas, privadas e da sociedade civil, bem como uma análise dos serviços ofertados por estas instituições, frente às demandas apresentadas pelos usuários. A metodologia de pesquisa incluiu análise documental, visita as instituições que compõem a Rede de Apoio ao Egresso e entrevistas. O referencial teórico foi constituído por abordagens de Políticas Sociais e Penais, Redes Sociais e Movimentos Sociais, de Atendimento ao Preso e Assistência ao Egresso. Como resultante, verificou-se que em decorrência da estruturação do sistema penitenciário, que não promove a inserção social do egresso, é que se instala uma imensa demanda de egressos, completamente despreparados para enfrentar o resgate de suas vidas. Assim, pode-se considerar que o estudo colabora para constatação de que não existe uma política pública nacional efetiva de atendimento ao egresso, o que faz com que a ação da rede socioassistencial, seja responsabilizada pela resolução de demandas apresentadas e a promoção da dignidade deste segmento de usuários.

\section{Palavras-chave}

Assistência Social; Egressos; Inserção Social; Rede Socioassistencial; Sistema Penitenciário. 


\section{Abstract}

Leiras, Mariana; Brotto, Marcio Eduardo (Advisor). Socioassistencial Netowrk Egress of Prisions System: Challenges in its construction. Rio de Janeiro, 2015. 123p. MSc. Dissertation - Departamento de Serviço Social, Pontifícia Universidade Católica do Rio de Janeiro.

This work focuses in the organization processes of Social Assistance Network, geared to Egress of Prisons. The need to analyze the network organization processes came from the inclusion in the Support Network Egress of Prisons (RAESP), whose purpose is to integrate actions to promote egress citizenship. To this end, we conducted a survey inspection of initiatives in the municipality of Rio de Janeiro, in public, private, civil society and an analysis of the services offered by these institutions and the demands presented by users. The research methodology includes legislative analysis, visit the institutions that make up the Support Network Egress and interviews. As a result, it was found that due to the structuring of penitentiary system that does not promote the inclusion of graduates that install a rouge demand of egress leaving the prison system, completely unprepared to deal with the rescue of their lives. Therefore, it can be considered that the study contributes to the realization that there is not a national public policy customer egress, which makes the action of social assistance network responsible for resolving presented demands and promoting the dignity of these segment users.

\section{Keywords}

Social Assistance; Egress; Social Integration; Social-assistance Networking; Penitentiary System. 


\section{Sumário}

1. Introdução

2. Política Social e Questão Social 22

2.1. Proteção Social e o Papel do Estado 22

2.2. Reconfiguração da Política Social e Sociedade 33

Civil

3. Debate sobre Rede 44

3.1. Redes Sociais e Rede de Movimentos Sociais 44

3.2. Rede de Atendimento: debate reflexivo do 49 atendimento dentro da prisão

3.3. Assistência ao Egresso

4. O Trabalho em Rede 70

4.1. Rede de Apoio ao Egresso do Sistema 70 Penitenciário - RAESP

4.1.1. Resultados e Discussão 80

4.1.1.1. Perfil das instituições 82

4.1.1.2. Natureza 82

4.1.1.3. Ano de Fundação 83

4.1.1.4. Cargo ou função do entrevistado 84

4.1.1.5. Área de atuação 84

4.1.1.6. Tempo de participação na RAESP 86

4.1.1.7. Público Alvo 87

4.1.1.8. Origem do Público atendido 88

4.1.2. Perfil do Público Alvo 89

4.1.2.1. Público dominante 90

4.1.2.2. Faixa etária 90 
4.1.2.3. Escolaridade 91

4.1.2.4. Média de tempo no sistema Penitenciário 92

4.1.2.5. Motivo de Inserção no sistema prisional 93

4.1.2.6. Principais demandas dos atendidos 94

4.1.3 Avaliação da Rede 94

4.2. Estudo de Caso: Um olhar dos (Pré) Egressos 103 em relação à Rede socioassistencial de de atendimento

$\begin{array}{ll}\text { 5. Considerações Finais } & 108\end{array}$

6. Referenciais Bibliográficas 112

$\begin{array}{lll}7 . & \text { Anexos } & 118\end{array}$

7.1. Anexo 1 - Questionário de Pesquisa: Rede de 118 Apoio ao Egresso do Sistema Penitenciário RAESP

7.2. Anexo 2 - Ata de constituição da Rede de Apoio

122 ao Egresso do Sistema Penitenciário 


\section{Lista de tabelas}

Tabela 1 - Ano de Fundação 83

Tabela 2 - Função do Entrevistado 84

Tabela 3 - Área de atuação $\quad 84$

Tabela 4 - Escolaridade 92

Tabela 5 - Tempo de reclusão 92

Tabela 6 - Principais demandas 94 


\section{Lista de quadros}

Quadro 1 - O que entende por rede? 95

Quadro 2 - Em sua opinião, qual a relação das Políticas 96 Públicas com as Redes Sociais?

Quadro 3 - Qual é o papel da Rede de Apoio ao Egresso, na vida dos usuários e para a Sociedade Brasileira?

Quadro 4 - Qual a importância da RAESP na condição de rede a egressos?

Quadro 5 - Qual o objetivo da instituição em participar da Rede

Quadro 6 - Considera que a RAESP alcança seus objetivos? De que forma/Por quê?

Quadro 7 - Quais os principais resultados da RAESP? 


\section{Lista de gráficos}

Gráfico 1 - Natureza 82

Gráfico 2 - Tempo de participação na RAESP 86

Gráfico 3 - Público Alvo 87

Gráfico 4 - Origem do Público 88

Gráfico 5 - Sexo do Público predominante 90

Gráfico 6 - Faixa etária 91

Gráfico 7 - Artigos/Delitos 93 


\section{Lista de abreviaturas e siglas}

ALERJ - Assembleia Legislativa do Estado do Rio de Janeiro

CEDAE - Companhia Estadual de Águas e Esgotos

CREJA - Centro de Referência de Educação de Jovens e Adultos

CNPJ - Cadastro Nacional da Pessoa Jurídica

CNAS - Conselho Nacional de Assistência Social

CONPE - Conselho Penitenciário

CNPCP - Conselho Nacional de Política Criminal e Penitenciária

CCS - Centro de Ciências Sociais

CISC - Centro de Integração Social e Cultural

DEPEN - Departamento Penitenciário Nacional

EAD - Ensino de Educação a Distância

EJA - Educação de Jovens e Adultos

FSC - Fundação Santa Cabrini

FUESP - Fundo Especial Penitenciário

FIOCRUZ - Fundação Oswaldo Cruz

FEVUC - Feira de Valores da Universidade Católica

ICCNNM - Instituto de Cultura e Consciência Negra Nelson Mandela

INFOPEN - Sistema Integrado de Informações Penitenciárias

ISAPS - Inspetor de Segurança e Administração Penitenciária

LEP - Lei de Execução Penal

LOAS - Lei Orgânica da Assistência Social

LPSPV - Laboratório de Práticas Sociais e Pesquisas sobre Violência

MDS - Ministério de Desenvolvimento Social

MP - Ministério Público

NOB - Norma Operacional Básica

NPJ - Núcleo de Práticas Jurídicas

ONG - Organização não governamental

ONU - Organização das Nações Unidas

OSCIP - Organização da Sociedade Civil de Interesse Público

OAB - Ordem dos Advogados do Brasil 
PAD - Prisão Albergue Domiciliar

PUC - Pontifícia Universidade Católica

PNAS - Política Nacional de Assistência Social

PPL - Pessoas Privadas de Liberdade

PSF - Programa de saúde da família

RAESP - Rede de Apoio ao Egresso do Sistema Penitenciário

SUAS - Sistema Único de Assistência Social

SEEDUC - Secretaria de Educação do Estado do Rio de Janeiro

SETRAB - Secretaria Estadual de Trabalho e Renda

SECONCl - Sindicato das Empresas da Construção Civil

SEAP - Secretaria de Estado e Administração Penitenciária

TJ - Tribunal de Justiça

UFRJ - Universidade Federal do Rio de Janeiro

UERJ - Universidade Estadual do Rio de Janeiro

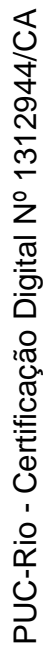

UNIRIO - Universidade Federal do Estado do Rio de Janeiro

VEP - Vara de Execução Penal 
Uma vacina preventiva de erros e violência se fará. As prisões se transformarão em escolas e oficinas. E os homens imunizados contra o crime, cidadãos de novo mundo, contarão as crianças do futuro, histórias absurdas de prisões, celas, altos muros, de um tempo superado. 


\section{Introdução}

O presente trabalho tem como objetivo analisar os processos de organização da Rede socioassistencial, voltada para atender os Egressos do Sistema Penitenciário do Rio de Janeiro. Esse trabalho surge a partir das reflexões desenvolvidas, através da linha de pesquisa: TRABALHO, POLÍTICAS SOCIAIS, SUJEITOS COLETIVOS, do curso de Mestrado em Serviço Social da PUC-Rio.

A partir de minha experiência profissional com egressos ${ }^{1}$ do Sistema Penitenciário, surge à aproximação com a temática que é fruto das discussões travadas em algumas áreas, tais: assistência social e sociojurídica. Esta aproximação teve início no período de realização do estágio curricular no Banco da Providência e posteriormente enquanto assistente social e coordenadora da Rede de Apoio ao Egresso do Sistema Penitenciário (RAESP), composta por instituições e fundações, privadas e do terceiro setor. Atualmente, mantenho aproximação com o tema, como coordenadora do Projeto Agência da Cidadania, que tem por objetivo a inserção de homens e mulheres que cumprem ou cumpriram penas privativas de liberdade, no Mundo do Trabalho.

A necessidade de analisar os processos de organização da Rede socioassistencial, voltada para atender os egressos do sistema penitenciário, surgiu a partir da inserção na Rede de Apoio ao Egresso do Sistema Penitenciário (RAESP), que teve sua fundação no ano de 2006, com o objetivo de integrar ações para promover a cidadania dos egressos do sistema penitenciário.

Nessa lógica de garantia de acesso, apresentaremos uma rede de serviços de atendimento ao egresso, constituída e em expansão no Município do Rio de Janeiro, que utiliza as práticas de intersetorialidade, apresentadas como formas de articulação e integralidade de suas ações e que foi motivadora para a realização deste trabalho.

\footnotetext{
${ }^{1}$ Considera-se egresso, o liberado definitivo, pelo prazo de 1 (um) ano a contar da saída do estabelecimento penal e o liberado condicional, durante o período de prova. Lei de Execução Penal (1984).
} 
A proposta da RAESP surgiu de instituições privadas, do terceiro setor, ONGs e fundações que já atuavam nesta temática mobilizando esforços para juntas, atenderem esse público e seus familiares.

Os objetivos da RAESP são: Viabilizar o acesso aos Direitos estabelecidos na Constituição da República Federativa do Brasil de 1988, na garantia de acesso a serviços para homens e mulheres egressos/as e internos/as do Sistema Penitenciário e seus familiares; atuar junto ao Conselho Penitenciário na solução das demandas apresentadas, em consonância com a Lei de Execução Penal - LEP/ 1984; reduzir o Índice de reincidência prisional no Município do Rio de Janeiro;

A RAESP não tem uma caracterização jurídica e seus membros possuem autonomia nas suas deliberações. A constituição dessa rede partiu de esforços de instituições públicas e privadas que pretendem atuar pela causa do egresso penitenciário, cuja principal demanda é a inclusão pelo trabalho.

Para a elaboração e determinações propostas às ações, são realizadas quinzenalmente reuniões de forma rotativa em cada instituição participante. Nessas reuniões são discutidos temas relevantes sobre o que tem sido feito pela inclusão dos egressos em cada instituição e propostas para criação de fóruns.

A partir dessa inserção, as reflexões configuram o debate na garantia de direitos. Diante de um sistema que não contribuir para inserção social; nem dar ao preso chance de retornar a sociedade tendo oportunidades de seguir um novo caminho.

O Sistema Penitenciário nada mais é do que um aparelho destruidor de sua personalidade, pelo qual não serve para o que diz servir, neutraliza a formação ou o desenvolvimento de valores; estigmatiza o ser humano; funciona como máquina de reprodução da carreira no crime; introduz na personalidade aprisionização da nefasta cultura carcerária; estimula o processo de despersonalização; legitima o desrespeito aos direitos humanos. (Oliveira, 1996, p. 43.)

Em decorrência deste sistema penitenciário, que não promove a inserção social do egresso é que se instala uma imensa demanda de egressos que saem do sistema penitenciário completamente despreparado para enfrentar o resgate de suas vidas. Na maioria dos casos, negros e pobres, vindos das camadas mais desfavorecidas da sociedade, onde lhes foram negadas oportunidades de construção de cidadania. (Dados extraídos do site do Departamento penitenciário Nacional - DEPEN, 2014). 
Esse cenário configura a importância das políticas sociais na construção da cidadania de homens e mulheres, egressos do sistema penitenciário e de suas famílias no Rio de Janeiro e no Brasil. Usuários das Políticas Sociais, que acessam aos serviços sociais, buscam a inserção em programas e projetos do Governo, que viabilizem o protagonismo desses sujeitos de direitos.

A Constituição Federal de 1988 determina que, a assistência social passe a integrar o sistema de seguridade social do país, junto com a saúde e a previdência. A Assistência Social torna-se direito do cidadão e dever do Estado, configurando o Sistema de Proteção Social no Brasil.

A Política Nacional de Assistência Social - PNAS/2004 foi construída em meio a um longo processo de debates capitaneado pelo Ministério de Desenvolvimento Social - MDS. Trata-se de uma política que junto com as políticas setoriais, considera as desigualdades socioterritoriais, visando seu enfrentamento à garantia dos mínimos sociais, ao provimento de condições para atender à sociedade e à universalização dos direitos sociais.

Tem por objetivo, prover serviços, programas, projetos e benefícios de proteção social básica e, ou especial para famílias, indivíduos e grupos que deles necessitarem.

E contribuir com a inclusão e a equidade dos usuários e grupos específicos, ampliando o acesso a bens e serviços socioassistenciais básicos e especiais.

O egresso do sistema penitenciário se caracteriza como usuário da política de assistência social, pois são pessoas em risco social, com perda ou fragilidade de vínculos de afetividade, identidades estigmatizadas e pertence a um grupo que se encontra em situações de vulnerabilidades, inserção precária ou não inserção no mercado de trabalho formal e informal, através dos ditos biscates e trabalhos como ambulantes. Nesse contexto, a política de Assistência Social disponibiliza a Proteção Social Básica e Proteção Social Especial, para esse segmento.

Partimos do pressuposto que a Rede Socioassistencial no município do Rio de Janeiro ainda mostra fragilidade. Não apresentando um conjunto de serviços, coerente com as demandas, fazendo com que esses egressos, sintam-se desprotegidos de seus direitos.

Acreditamos que analisar os processos de organização da Rede Socioassistencial voltada para atender os egressos do Sistema Penitenciário e a oferta de serviços no município do Rio de Janeiro, é de fundamental importância 
para a construção de estudos que visem chamar a atenção do meio acadêmico para o desenvolvimento de pesquisas que busque um tratamento para esta expressão da questão social. Estudar quais os mecanismos utilizados pela Rede que possibilitam a inserção social do egresso poderá servir de referência para futuros projetos e criação de políticas públicas para esse segmento.

No que se refere aos procedimentos metodológicos para este estudo, o primeiro elemento a ser tratado refere-se à sua abordagem. Silveira \& Córdova (2009) definem dois tipos de abordagem: qualitativa e quantitativa. A nosso ver, este estudo apresenta uma abordagem mais quantitativa, pois partimos de critérios definidos de que os dados serão captados a partir da compreensão de um grupo social, de uma organização, entre outros. Entretanto, destacamos a necessidade de incorporar a pesquisa qualitativa, visto que algumas questões serão respondidas qualitativamente, como é o caso da apresentação da Rede, pelos seus integrantes e as demandas apresentadas pelos egressos, que utilizam as redes assistenciais de atendimento.

Quanto aos procedimentos técnicos de coleta dados, optou-se pela pesquisa de campo, que, segundo Gil (2002), constitui o modelo clássico da Antropologia, mas tem sido amplamente utilizada na Sociologia, na Educação, na Saúde, entre outros. Trata-se de um procedimento que focaliza comunidades, que não é necessariamente geográfica, visto que pode abranger grupos sociais distintos, tais como, comunidade profissional; institucional, de estudo, ou voltado para qualquer outra atividade humana. A pesquisa de campo se desenvolve, essencialmente, por meio de observação direta das atividades do grupo pesquisado e de entrevistas com informantes para captar suas explicações e interpretações sobre o fenômeno pesquisado.

Nesse sentido, ressaltamos que foram utilizados instrumentos de coleta de dados tais como: entrevistas semiestruturadas com os membros da RAESP, com aplicação de um questionário (em anexo) previamente elaborado conforme definição dos objetivos que se pretende alcançar.

Sobre o recorte espacial ou universo de pesquisa, informamos que foi composto das 12 representantes de instituições que compõem a RAESP, que prestam assistência aos egressos no município do Rio de Janeiro. Desse total, identificamos sua natureza, os serviços ofertados, o perfil dos usuários atendidos e as demandas apresentadas. 
Quanto ao grupo social, ou atores sociais que responderam as questões desse estudo, foram compostos de assistentes sociais, psicólogos, pedagogos, advogados e egressos, responsáveis das instituições. Analisamos a organização dessas instituições e como atuam em Rede.

Por fim, sobre a organização e análise dos dados, destacamos que, na abordagem qualitativa, os dados serão tratados a partir das respostas identificadas nos discursos dos atores sociais. $\mathrm{Na}$ abordagem quantitativa, pretende-se sistematizar os dados por meio de apresentação gráfica (tabelas e gráficos). As análises dos dados foram fundamentadas no quadro teórico apresentado sobre o objeto em questão. Vale informar que o quadro teórico será elaborado com base em leituras de autores que priorizam o debate sobre as redes de atendimento; em documentos oficiais e outros materiais que visam contribuir para explicitar as questões que envolvem Redes e assistência ao egresso no Brasil.

Iniciaremos esse estudo discorrendo sobre a Política Social e Questão social: a aglutinação dos problemas sociais que atingem a sociedade no processo histórico. Tais problemas decorrentes da contradição trabalho versus capital, que se solidifica com a sociedade capitalista. Ainda nesse capítulo, trataremos a proteção social brasileira que se consolidou com a Constituição Federal de 1988, quando garante os direitos sociais e humanos como universais. O Papel do Estado, a Reconfiguração da Política Social e a Sociedade Civil.

No capítulo seguinte, analisaremos o debate sobre Rede. As Redes Sociais e de Movimentos Sociais: Como surgem as redes e para quê? Além disso, apresentaremos a rede de atendimento, dentro da prisão à assistência aos egressos. A quase inexistência de políticas para esses segmentos, tem transferido as ações para a sociedade civil que busca através da construção de redes de apoio ao egresso, quebrar as imensas barreiras que são constituídas de diversos fatores tais como: a precariedade do mercado de trabalho, o estigma ao egresso, a falta de apoio do poder público, dentre outros.

No ultimo capítulo, apresentaremos a Rede de Apoio ao Egresso do Sistema Penitenciário - RAESP, as instituições que a compõe, ações e parcerias. Discutiremos os resultados identificados na pesquisa realizada junto aos membros da Rede. E, ainda, o estudo de caso realizado, a partir do olhar dos egressos (e internos- pré egressos) sobre a referida Rede. Foram realizadas entrevistas e aplicação do questionário de pesquisa, com 3 membros individuais da RAESP. 
Dois internos do regime semiaberto (pré-egressos) e um egresso em Liberdade Condicional. A fim de compreendermos, o papel da rede socioassistencial para o segmento de usuários.

A seguir, finalizaremos trazendo nossas considerações finais sobre o estudo aqui empreendido e propostas futuras. 


\section{2 \\ Política Social e Questão Social}

\section{1. Proteção Social e o Papel do Estado}

Pertencer a um Estado garantidor de direitos é sem dúvida, um aspecto central na efetivação de direitos, porém, como fazer para apropriar-se desses direitos ditos naturais e inerentes a todo ser humano?

Uma de suas expressões se materializa concernente ao princípio da universalidade, contra o modelo Sociedade/Estado baseado nos privilégios e troca de favores.

A história, internacional/nacional, nos relata como foi, está sendo e será difícil essa conquista. Pois ainda estamos lutando. Um indivíduo para se considerar detentor dos direitos a ele designado, necessita de um "aval" do Estado para dele usufruir.

Façamos um breve passeio histórico sobre o surgimento desses, que seriam um dos temas, no campo de estudos científicos sobre transformações sociais, mais dinâmicos e que estão sempre em transformação: Política Social ${ }^{2}$ e Questão Social ${ }^{3}$.

Para melhor compreensão do papel das políticas sociais implementadas por um governo, é essencial a compreensão da visão de Estado e de política social que amparam tais ações e programas de intervenção.

Utilizaremos o conceito de Estado gramsciano, onde segundo o filosofo, embora o Estado conserve seu caráter classista, não poderia ser apenas um comitê

\footnotetext{
2 "Política social reflete a direção política das relações econômicas. A combinação específica, imposta pela correlação efetiva de forças, de incentivos à acumulação e ao crescimento, recursos para a provisão de meios de subsistência aos mais carentes e ações redistributivas visando a alcançar um certo patamar de equidade". (Abranches, 1989)

${ }^{3}$ A expressão "questão social" começou a ser utilizada na terceira década do século XIX, surge para nomear o fenômeno do pauperismo. A pauperização da população trabalhadora é o resultado do capitalismo industrial e crescia da mesma forma que aumentava a produção (Netto, 2001, p. 42).
} 
de negócios burgueses. As demandas das classes subalternas deveriam ser respondidas por ele.

O Estado possui a tarefa da manutenção da ordem social, organizando novas formas de estabelecer o consenso, através da formulação e disseminação de um conjunto de valores e normas políticas, sociais e culturais. (Gramsci, 1968)

Políticas sociais são aqui entendidas como o Estado implantando um projeto de governo, através de programas e/ou de ações voltadas para setores específicos da sociedade. Se referem a ações que determinam o padrão de proteção social implementado por um Estado, voltadas, em princípio, para a redistribuição dos benefícios sociais apontando para a diminuição das desigualdades estruturais produzidas pelo desenvolvimento socioeconômico. As políticas sociais possuem raízes nos movimentos populares do século XIX, voltadas aos conflitos surgidos entre capital e trabalho, no desenvolvimento das primeiras revoluções industriais.

A Revolução Industrial ocorreu por conta de uma série de mudanças nas atividades produtivas, principiadas no século XVIII, na Inglaterra e nos séculos XIX e XX se espalhou por outros países como França, Bélgica, Holanda, Rússia, Alemanha e Estados Unidos.

A evolução técnica foi o cerne da Revolução Industrial, mas não seu elemento principal. Analisando o termo revolução, em seu significado histórico, sugere-se um conjunto de transformações importantes, a Revolução Industrial corresponde plenamente a esse significado.

No plano técnico, houve alterações não apenas na produção de bens de capital (máquinas, equipamentos) e de artigos de consumo, como também nas técnicas agrícolas e nos meios de transporte. Mas, acima de tudo, a Revolução Industrial foi marcada pelas modificações econômicas e sociais. E acarretou ainda mudanças no campo político, intelectual e comportamental.

Considerações marxistas afirmam que a "política social" é resultado do desenvolvimento capitalista, considerada indispensável para garantir a acumulação do capital, bem como regular os conflitos de classe. Luta de classes é uma expressão que tem origem no trabalho do filósofo, economista, sociólogo, historiador, jornalista e revolucionário socialista alemão Karl Marx, frequentemente citada como uma característica de seu pensamento.

O filósofo busca com este termo definir o confronto entre duas classes distintas, a burguesia, e o proletariado, que atuariam como classes antagônicas em 
meio ao modo de produção capitalista. Pretendendo caracterizar não apenas uma visão econômica da história, mas também uma visão histórica da economia. A teoria marxista também procura explicar a evolução das relações econômicas nas sociedades humanas ao longo do processo histórico. O caráter antagônico das relações de produção e distribuição origina interesses contraditórios que se manifestam na luta de classes, quer entre as próprias classes dominantes, aristocracia e burguesia, quer entre estas classes e os produtores individuais ou os trabalhadores. Este antagonismo assume, por vezes, a forma de conflitos violentos.

De certa forma, entendemos que a existência de políticas sociais é um fenômeno associado à constituição da sociedade burguesa, ou seja, do especifico modo capitalista de produzir e reproduzir-se. Evidentemente que não desde a sua gênese, mas quando surge um reconhecimento da questão social inerente às relações sociais nesse modo de produção, ao momento em que os trabalhadores assumem um papel político. De tal maneira que existe certo consenso em torno do final do século XIX como período de criação e multiplicação das primeiras legislações e medidas de proteção social, com destaque para Alemanha e Inglaterra.

A "questão social" é uma expressão criada no final do século XIX, em referência às conturbações da sociedade industrial emergente, foi analisada ao longo do século XX no âmbito do desenvolvimento do Estado Providência no Ocidente.

Castel (2005) nos assegura que o hiato entre a organização política e o sistema econômico permite assinalar, pela primeira vez com clareza, o lugar do "social": desdobrar-se nesse entre dois, restaurar ou estabelecer laços que não obedecem nem a uma lógica estritamente econômica nem a uma jurisdição estritamente política. "O social” consiste em sistemas de regulações não mercantis, instituídas para tentar preencher esse espaço. Em tal contexto, a questão social torna-se o tema do lugar que as franjas mais dessocializadas dos trabalhadores podem ocupar na sociedade industrial. A resposta para ela será o conjunto dos dispositivos montados para promover sua integração. (Castel, 2005, p. 31) 
Inserimos-nos no debate atual que amplia a dimensão política do Estado para a compreensão de suas funções no capitalismo contemporâneo, contribuindo para a ampliação das revelações sobre a relação do Estado e as mudanças sociais.

O ponto de partida dessa análise é o de que, a luta pela afirmação dos direitos sempre foi uma luta contra o capital, parte de um processo de acumulação de forças para uma forma de desenvolvimento social, que possa vir a contemplar a relação de desenvolvimento de cada um e de todos os indivíduos sociais.

Uma relação que também deve ser considerada fundamental é a que se estabelece entre Estado e políticas sociais, ou melhor, entre a concepção de Estado e a política que este implementa, em uma determinada sociedade, em determinado período histórico.

As bases da política social brasileira foram construídas de acordo com o curso da modernização com a qual o país encontrar-se-ia, a partir de então, comprometido, regulando aspectos relativos à organização dos trabalhadores assalariados dos setores modernos da economia.

Este histórico sinaliza que a proteção social ${ }^{4}$ oferecida pelo Estado surge fortemente ligada às relações de trabalho.

Não por acaso, parte significativa das proteções oferecidas ainda hoje, estão voltadas para a garantia de direitos trabalhistas e para assegurar renda àqueles impossibilitados de trabalhar, como o seguro desemprego, a licença maternidade, auxilio doença, aposentadorias e pensões, seguidas por inúmeras outras medidas de proteção ao trabalhador, tomadas após 1930.

Sua origem no país tendo como base o Welfare State ${ }^{5}$, permitindo que transformações, aliadas ao desenvolvimento econômico e ao processo de industrialização, objetivasse alcançar a regulação dos conflitos surgidos do novo processo de desenvolvimento econômico e social do país.

\footnotetext{
4 “A proteção social pode ser definida como um conjunto de iniciativas públicas ou estatalmente reguladas para a provisão de serviços e benefícios sociais visando a enfrentar situações de risco social ou de privações sociais." (Jaccoud, 2009:58) Para Castel (2005: 92), a proteção social é condição para construir uma "sociedade de semelhantes: um tipo de formação social no meio da qual ninguém é excluído" Para o autor ser protegido do ponto de vista social é dispor, de direito, das condições sociais mínimas para ter independência.

${ }^{5}$ Welfare State é uma transformação do próprio Estado a partir das suas estruturas, funções e legitimidade, buscando garantia de renda mínima às famílias, dar-lhes segurança nas "contingências sociais e, assegurar aos cidadãos qualidade nos serviços sociais". Tendo configuração diferente em cada país que se fundamenta, no caso do Brasil, apresenta-se como uma política social com objetivo de retificar as ações de um Estado mínimo histórico, como consequência de distorções crônica de seu papel neste cenário.
} 
A proteção social está relacionada com a acumulação e legitimação exercidas pelo Estado capitalista. Transforma a sociedade em arena de conflitos, onde quase sempre os direitos sociais são subjugados, restringidos ou focalizados.

Se de certa forma, a proteção social foi criada principalmente com o objetivo de atender aos setores organizados da classe trabalhadora urbana, fundamentado no sistema de Previdência Social ${ }^{6}$, lacunas ocorreram na execução dessa proteção social, afetando sobremaneira sua efetivação.

Do ponto de vista social redefiniram-se os mecanismos legais e institucionais, instituindo renovadas formas de intervenção aos sistemas de proteção social determinadas por ajustes econômicos e contrarreformas sociais que garantiram a acumulação do capital, culminando no redirecionamento do papel do Estado enquanto protetor social, tornando-se protetor do capital.

Werneck Vianna (2004) assegura que "Quando o Estado adota o conceito de Seguridade Social em substituição ao de previdência significa afirmar que a proteção social deve ser estendida a todos que dela necessitam e não apenas àqueles que trabalham, ou contribuem".

Portanto, esse papel deve ser reconsiderado nos dias atuais. Essa generalização de medidas de seguridade social no capitalismo, no entanto, iniciouse no período pós Segunda Guerra Mundial, no qual se assiste a singular experiência de construção do Welfare State em alguns países da Europa Ocidental com destaque para o Plano Beveridge ${ }^{7}$ (Inglaterra, 1942).

Tal variedade, quanto à cobertura mais ou menos universal, padrão de financiamento (redistributivo ou não, contributivo ou não), dentre outros aspectos que poderiam compor uma avaliação desse universo, está relacionado às relações entre classes sociais e segmentos de classe e condições econômicas gerais, que interferem nas ações políticas e econômicas dos governos.

\footnotetext{
${ }^{6}$ A Previdência Social, mediante contribuição, tem por fim assegurar aos seus beneficiários meios indispensáveis de manutenção, por motivo de incapacidade, desemprego involuntário, idade avançada, tempo de serviço, encargos familiares e prisão ou morte daqueles de quem dependiam economicamente. (Lei $\mathrm{n}^{\circ} 8.213 / 91$ )

${ }^{7} \mathrm{Na}$ Inglaterra, o Plano Beveridge (1941), reformado em 1946, elaborado pelo Lord Beveridge, tinha como objetivo constituir um sistema de seguro social que garantisse ao indivíduo proteção diante de certas contingências sociais, tais como a indigência ou incapacidade laborativa. O Plano Beveridge tinha como características: a) unificar os seguros sociais existentes; b) estabelecer a universalidade de proteção social para todos os cidadãos; c) igualdade de proteção social; d) tríplice forma de custeio com predominância de custeio estatal. http://jus.com.br/artigos/9311/seguridade-social.
} 
Diferente da trajetória que determinou o Welfare State, a proteção social brasileira, orquestrada pela ofensiva do capital e conduzida pela burguesia para estabelecer novos parâmetros na relação entre o capital, o homem e seu trabalho, produziu tão somente, acumulação, independente de consequências sociais, políticas e outras, com a exploração do trabalho vivo e dominação.

As medidas assistenciais surgem como um componente da rede de relações transmitidas à sociedade, passando a articular-se às estratégias das relações do Estado com as classes trabalhadoras, como uma das áreas instrumentais do intervencionismo crescente do Estado na sociedade civil.

A sociedade é abarcada por uma rede de relações autoritárias, aliadas às instituições e aos processos sociais, tendo como ponto central uma forma de autodefesa das classes dominantes. Consequentemente, o novo modelo político que se impõe, tem em vista a adequação do poder do Estado às novas necessidades da acumulação, de modo a fortalecer a grande unidade de produção.

O ponto de clivagem deste cenário derivou em um descompromisso com as classes trabalhadoras: aumento da taxa de desemprego, destruição de postos de trabalho, redução de salários e gastos com as políticas sociais, resultando em desigualdades sociais.

Fundado na utopia de vencer a insegurança social e o medo do futuro, instalados pela Revolução Industrial, o Estado Providência foi se estruturando para responder aos riscos e tensões da nova ordem econômica.

Atualmente o sistema brasileiro de proteção social está organizado sob três pilares principais:

-Política de previdência social, que tem caráter predominantemente contributivo e visa garantir renda para as situações de risco.

-Política de assistência social, de caráter não contributivo e acessível a todos.

-Política de saúde, igualmente gratuita e de acesso irrestrito.

O Estado Providência é a intervenção condicionante do Estado sobre a sociedade. Do Estado vai-se exigir que ele seja o modelador da vida econômica e social, como produtor de bens, como empresário, como agente de crédito, como organizador de serviços públicos. O Estado deverá definir as metas que à sociedade interessa alcançar e a ele cabe, igualmente, o planejamento, a orientação e o controle da atividade dos restantes sujeitos econômicos, com vista a que tais objetivos sejam efetivamente realizados. A realidade econômica e social 
passa a ser um material que ao Estado compete estruturar de acordo com outras condicionantes, nomeadamente as de caráter político-jurídico.

Embora as condições para o surgimento e generalização de políticas sociais tenha o referido tempo histórico, o debate sobre o Bem-Estar na sociedade, sobre o que fazer com os pobres e - muito especial - sobre o papel do Estado nesses processos, precede em muito esse tempo, tornando necessário um breve contato com alguns argumentos clássicos, recorrentes no debate contemporâneo sobre política social.

Bravo \& Pereira (2006) também nos oferecem um panorama do desenho inicial do papel do Estado nas sociedades da Idade Média, para melhor compreendermos a análise, que tomamos como exemplo para dar prosseguimento a nossa reflexão:

[...] Temos na nossa história a herança de Roma, para auxiliar no estudo cronológico do papel do Estado com a proteção social, a ideia de comunidade ampliada que abarcava a humanidade toda, e a administração centralizada com a dupla significação: como base da civilização e como garantia da unidade estatal. Dessa concepção, nasceram o conceito de cidade-capital e novas obrigações por parte do Estado, a saber: zelar pela justiça, pela paz, pela segurança do comércio, pelos meios de comunicação. Desenha-se, a partir de então, o conceito de serviços público regulador das relações humanas e das atividades econômicas estratégicas. (Bravo \& Pereira, 2006)

Couto (2000) nos convida a refletir quando lembra que:

"Os direitos, enquanto constitutivos de um patamar de sociabilidade, tem jogado papel importante na sociedade contemporânea que, ao discuti-los, coloca em xeque as formas de relação que são estabelecidas, tornado tenso o movimento por tê-los reconhecidos em lei, protegidos pelo Estado, e, mais do que isso, explicitados na vida dos sujeitos concretos". (Couto, 2000, p.37).

Ressaltamos que as mudanças estruturais verificadas nas sociedades modernas criaram novos e complexos problemas para o Estado. A questão social, que eclodiu na segunda metade do século XIX, no rastro da Revolução Industrial, impôs-se como fato perturbador da ordem e das instituições liberal-burguesas. Com efeito, a questão social, constituída em torno do pauperismo e da miséria das massas, representou o fim de uma concepção idealista de que a sociedade, por si só, ou quando muito, acossada pela policia pudesse encontrar soluções para os problemas sociais. 
Uma das consequências mais notáveis dessas mudanças foi que a regulamentação da vida individual se transformou em tema de direito público. Com isso, os direitos privados, defendidos pelos liberais, perderam a primazia perante o Estado.

Não podemos deixar de contextualizar que, do ponto de vista social, os acontecimentos político-econômicos das últimas décadas sinalizaram progressivo distanciamento das prerrogativas constitucionais. A proteção social foi regulamentada de forma fragmentada e desarticulada, contrariando os princípios de universalidade presente em sua concepção, além de termos vivenciado significativa precarização de suas políticas.

Para dar conta das crescentes demandas sociais advinda, principalmente, da referida "questão social", então desencadeada a que se viu obrigado a responder, o Estado capitalista, até por uma questão de sobrevivência, renunciou à sua posição equidistante de árbitro social para tornar-se francamente interventor. E, nesse papel, ele passou não apenas a regular com mais veemência a economia e a sociedade, mas também a empreender ações sociais, prover benefícios e serviços e exercer atividades empresariais... dando origem ao Estado de Bem-Estar Social, como preferimos chamar. (Bravo \& Pereira, 2006, p.254).

A ascensão especial à condição de direito do cidadão e dever do Estado representou, inegavelmente, um aperfeiçoamento político-institucional de monta no âmbito da regulação estatal; mas tal ascensão não se deu por cima ou por fora dos conflitos de classe. Nesses conflitos, ganha proeminência a histórica participação dos trabalhadores em sua luta contra o despotismo do capital e o poder tendencialmente concentrador do Estado.

“[...] Foi por meio da incorporação da questão social na agenda política e da sua paulatina transformação em questão de direitos, que a integração do Estado com a sociedade civil tornou-se uma realidade irrecusável". (Bravo \& Pereira: 2012, p.37)

Nesta linha, por esse Estado até hoje é ofertado, através de leis, programas e projetos, dentre outros, serviços para que tal direito seja garantido. Embora no Brasil temos variados exemplos dessas ofertas, após análise mais cuidadosa, identificamos seletividade, burocracias e politicismos na aplicação de tais direitos encobertos por leis que deveriam garantir sua universalidade.

Ao Estado reserva-se o poder de regular as políticas sociais, orientando-se no sentido de beneficiar a participação de instituições privadas na área da 
prestação de serviços sociais, como campo de investimento do capital ou meio de obtenção de vantagem fiscais, perpetrando a qualidade dos serviços já subordinada aos requisitos de rentabilidade das empresas.

Com o caminhar dos tempos, fomos testemunhas oculares através, da lupa da história dos efeitos colaterais desse cenário:

[...] o crescimento da pobreza e da desigualdade social, nos últimos anos tem sido uma das consequências mais sérias do modo neoliberal de regular a economia e a sociedade. Tal fenômeno foi determinado, sobretudo, pela diminuição das ofertas de empregos, acompanhada das desigualdades de salários, como resultado da desregulamentação do mercado de trabalho e da diminuição da progressividade fiscal; isto é, da redução do encargo tributário direto, que onera, progressivamente, quem possuía mais renda, e do aumento dos impostos indiretos, que incidia mais pesadamente sobre os trabalhadores e consumidores de baixa renda. (Bravo \& Pereira, 2012, p.41)

Esse panorama histórico da gênese da proteção social no Brasil justifica a teoria de Weber (1864-1920) sobre o Estado onde afirma que:

"O Estado é uma organização política repressora, destinada a perpetuar relações de dominação e sujeição por meio do aparelho militar e burocrático... é a única fonte de direito à violência, sustentado pelo consentimento dos dominados e por um quadro jurídico e administrativo que lhe confere poder, racionalidade e legitimidade.” (Gramsci, apud Coutinho, 2006).

Ainda que a crítica de Gramsci sobre Estado relata que ambos são indissociáveis. E que esse poder lhe é concedido livremente, sendo a função do Estado, identificado com o conjunto de seus aparelhos repressivos, seria a de conservar e reproduzir tal divisão. Pois,

Segundo os ideais gramscianos, a guerra de posição não será efetivada pelas entidades dóceis do "terceiro setor", "parceiras do Estado", dependentes do Estado e do mercado, mas pela sociedade civil realmente organizada, pelos movimentos sociais, pelas organizações não-governamentais combativas e representativas, em busca de uma hegemonia, de uma sociedade justa, igualitária e materialmente democrática e não penas formalmente democrática, como é a sociedade brasileira na atualidade. (Coutinho,1999, p.127-129).

Nos dias atuais, a referida proteção social deve ser reconhecida como um direito, mas este reconhecimento não tem sido suficiente para torná-lo um direito legitimo. Par tal é necessário atribuir caráter de direito às ações realizadas pelo Estado. 
O entendimento da proteção social como direito convive em seu cotidiano de forma conflituosa com procedimentos tradicionais de seleção, classificação oriundas das deficiências de estruturas nos serviços, da escassez dos benefícios e dificuldade de reconhecer os cidadãos como sujeitos de direitos.

No âmbito da proteção social definiu-se um conjunto de direitos que devem ser afiançados. Nesta linha, o arco de alianças entre os sujeitos deve reforçar tais direitos, dentre os quais destacaríamos o direito aos serviços e benefícios de forma articulada e o direito a participação social.

Ao pensarmos sobre esses aspectos trazemos para o cerne das nossas reflexões os desafios de fazer com que, "Esses sujeitos conheçam e reconheçam nesse sistema uma política de direitos e com isso superem os processos alienantes, disciplinadores e subalternizados pelos quais os sujeitos historicamente foram submetidos" (Yazbek, 1993, p.157).

Pode-se identificar na trajetória histórica da proteção social a construção de inúmeros caminhos demandadas pelas próprias necessidades decorrentes das práticas sociais, que traduzem uma busca intensa pela sua legitimação. Nesse sentido busca-se uma mudança no âmbito da regulação estatal.

Medidas advindas do Estado consolidaram um status de "cidadania regulada", termo proposto por Santos (1979) para denunciar que este sistema privilegia as categorias profissionais de maior importância para o processo de desenvolvimento do país, relegando aos demais, especialmente aos não empregados, cabendo ressaltar o caso dos egressos do sistema penitenciário que é o segmento tratado neste trabalho, e aos incapacitados de trabalhar, uma condição de não cidadão, materializada pela falta de acesso aos serviços ou por disponibilidade precária.

No caso dos egressos do sistema penitenciário, o que tributa para esse desprivilegio, seria o crônico preconceito com esse segmento da sociedade, conforme abordaremos com mais ênfase nos próximos capítulos desse trabalho.

É importante o entendimento de que um sistema de proteção social mais abrangente deve ser composto por outras políticas setoriais, visto que os riscos aos quais a sociedade está exposta ultrapassam o escopo da capacidade protetiva de uma única política.

Como pôde ser observado, para além dessa mudança substantiva na intervenção estatal, devem-se ampliar suas fronteiras, ato reivindicado pelos 
trabalhadores excluídos do pacto welfwreano. Se as demandas de proteção social por parte dos trabalhadores, ou não trabalhadores, se ampliam, cabe ao Estado respondê-las.

“Os altos índices de desproteção, a carência de serviços sociais e a necessidade de ampliação da qualidade dos serviços existentes, demonstram a necessidade urgente e inadiável de se adequar a arquitetura institucional desse sistema." (Instrumental Metodológico do SUAS - Estado do Rio de Janeiro 2012)

A professora Maria Lucia Werneck Viana ${ }^{8}$, também nos lembra do desmonte silencioso do sistema de proteção social no contexto brasileiro atual, referindo-se a um arraigado movimento conservador que, por não aceitar os avanços sociais previstos na Constituição Federal de 1988, enfraquece na surdina, os próprios fundamentos do edifício constitucional.

A constituição de um país é a principal agência de diretos. Porém, o Estado Constitucional que se defende não é aquele que, nos termos de Habermas (1981), coloniza a sociedade, mas sim, um Estado democrático; isto é, um Estado que conviveria com a participação da sociedade nos fóruns de discussão sobre decisões de interesse geral, mas sem abdicar de seu compromisso como o bem-estar dessa sociedade. (Bravo \& Pereira, 2012, p.43-44)

O conceito de proteção social, "depositário de justiça social”, pleno de uma simbologia sinalizadora de cidadania, segue inscrita na agenda brasileira, porém, vazia de conteúdo concreto e destituído de qualquer mecanismo de operacionalização.

Essa reflexão seguiu na direção de conduzir a um objetivo: vislumbrar a evolução ou o desenvolvimento direcionado a promover a superação das vulnerabilidades e o enfrentamento dos riscos que limitam o exercício da cidadania e a efetivação da proteção social e o papel do Estado.

Assim, reafirmamos que, embora com avanços e retrocessos na proteção social, para maior efetividade, deve-se conclamar a participação popular, da sociedade, com seu papel nos espaços de controle social, representado nos conselhos vinculados a execução de ações voltadas as Políticas Sociais.

\footnotetext{
${ }^{8}$ Ex Decana do Centro de Ciências jurídicas e Econômicas da UFRJ.
} 


\section{2. Reconfiguração da Política Social e Sociedade Civil}

As reformas constitucionais são tradições políticas no Brasil, sendo matéria obrigatória na República que segundo Vieira (1997), ocorreram depois da década de 20. O cenário histórico brasileiro nos mostra que desde a Constituição Federal de 1988, que se almejou inaugurar um novo paradigma para a Política Social, apontando para o seu status de direito.

Nos anos que se seguiram, leis e normas foram criadas como forma de efetivação da política social brasileira: Sistema Único de Saúde (SUS), Lei Orgânica de Assistência, (LOAS, 1993) Sistema Único de Assistência Social (SUAS, 2003), Política Nacional de Assistência Social (PNAS, 2004) dentre outras. Muito vem sendo os desafios para a construção e gestão desses sistemas que tentam reconstruir a Política Social brasileira.

As grandes transformações econômicas e sociais, especialmente com o rearranjo do mercado capitalista, a regionalização dos mercados e a crescente concentração do capital financeiro, vêm ocasionando o aumento da pobreza e da exclusão de vastos contingentes populacionais. Nesse cenário, crescem as demandas por ações estatais voltadas à proteção social dos que se encontram fora do mercado de trabalho ou vivendo sua precarização.

Atualmente, o país conta com grandes variedades de programas sociais modernos e descentralizados. Entretanto, variedade e descentralização caracterizam, em termos gerais, o perfil de nossa política social atual. Apesar dos progressos, alguns problemas permanecem. A falta de integração entre os programas sociais, a ausência de coordenação entre os três níveis de governo, uma intensa focalização na população mais carente, além das raras avaliações de impacto, têm contribuído para que as alterações por que passou a política social brasileira não tenham sido satisfatórias para se alcançar reduções significativas no grau de desigualdade de renda do país.

Contudo, é no é no âmbito da assistência social, uma das políticas mais utilizadas no atendimento ao egresso do sistema penitenciário, que se aposta materializar e fortalecer os direitos sociais, ampliar a cidadania e caminhar na superação das marcas estigmatizantes do egresso do e pré-egresso (internos em 
cumprimento de pena) do sistema. Além de associá-las a outras políticas estruturantes, como educação, saúde e trabalho.

Por conseguinte, "caberia à Assistência Social ações que cubram, reduzam ou previnam exclusões, riscos e vulnerabilidades sociais, bem como atendem às necessidades emergentes ou permanentes decorrentes de problemas sociais de seus usuários". (Sposati, 1995).

A Política de Assistência Social, com a aprovação da Lei Orgânica de Assistência social - LOAS, como direito do cidadão e dever do Estado. É definida no cap. I, art. $1^{\circ}$ da Lei ${ }^{\circ} 8742$ de 7 de setembro de 1993, da seguinte forma:

A assistência social, direito do cidadão e dever do Estado, é política de seguridade social não contributiva, que provê os mínimos sociais, realizada através de um conjunto integrado de ações e iniciativas pública e da sociedade, para garantir o atendimento às necessidades básicas. (Art. $1^{\circ}$ da Lei $n^{\circ} 8742$ de 7 de setembro de 1993)

Testemunhamos hoje um momento de esperança e decisivo para a concretização dessas políticas, num patamar de prioridade como política pública de proteção social, direcionada à realização dos interesses das classes subalternizadas e estigmatizadas da nossa sociedade.

Não podemos deixar de destacar que, a consolidação da Política Social na perspectiva do direito, pressupõe o contraponto ao passado caracterizado pelo clientelismo, pelo patrimonialismo, pelo engessamento burocrático e pela cultura do favor, "pois efetivar a consolidação da Assistência Social enquanto política pública, na perspectiva de concretizar os princípios e diretrizes conquistados, significa instaurar outro padrão civilizatório, comprometido com o fortalecimento do controle social na democratização dos processos decisórios, no protagonismo dos sujeitos sociais". (Lopes, 2006; Sposati, 2006).

Para Sposati (1997, p.10)

\begin{abstract}
"Propor mínimos sociais é estabelecer o patamar de cobertura de riscos e de garantias que uma sociedade quer garantir para todos os seus cidadãos. Trata-se de definir o patamar de dignidade abaixo do qual nenhum cidadão deveria estar". (Sposati, 1997, p.10, grifo da autora)
\end{abstract}

Sendo assim, poderia ser considerada uma "arma" contra as desigualdades sociais, se aplicada efetivamente enquanto política de Estado, de "estratégia 
fundamental no combate à pobreza, à discriminação, as vulnerabilidades e à subalternização econômica, cultural e política em que vive grande parte da população brasileira" (Yazbek, 2008, p. 20-21).

O papel da sociedade é de suma importância, através do controle democrático, se organizando e exercendo, no âmbito da política de assistência social, a construção de direitos e a instauração de formas inovadoras e efetivas para políticas de inclusão social e para seguridade social brasileira.

Trata-se, pois, de um processo contraditório, um momento onde mais uma vez, na história brasileira estão em disputa os sentidos dessa política, na perspectiva de forjar formas de resistência e defesa da cidadania dos excluídos, ou apenas reiterar práticas conservadoras e assistencialistas.

Ao Estado cabe ser garantidor do cumprimento dos direitos, responsável pela formulação das políticas públicas, exigindo que as provisões assistenciais sejam prioritariamente pensadas no âmbito das garantias de cidadania de direitos e de acesso para os serviços, programas e projetos sob suas responsabilidades. Foi o desafio lançado nessa perspectiva.

Todavia, lembramos mais uma vez que, com o advento da Constituição Federal de 1988, a política social, também se depara em um novo período, o qual Vieira denomina de "política social sem direitos sociais". A Constituição Federal de 1988 acolhe a política social nas áreas da educação, saúde, assistência, previdência social, trabalho, lazer, maternidade, infância, segurança. Determina os direitos dos trabalhadores urbanos e rurais, da associação profissional ou sindical, de greve e outros, contudo, se distanciando de um dos seus fundamentais princípios: universalização dos direitos sociais.

Identificamos, porém, que muitos desses direitos não são efetivados. Atingidos pelo capital e a burguesia na forma denominado de neoliberalismo ${ }^{9}$, que se utiliza da modernização para o processo de redimensionamento do capitalismo.

A política social no Brasil se compõe e se recompõe, todavia, sempre conservando seu caráter setorial e emergencial com o objetivo de sempre dar

\footnotetext{
${ }^{9}$ Ideias associadas ao liberalismo econômico que teve início nas décadas de 1970 e 1980 . Os seus seguidores defendem a liberalização econômica, livre comércio e a redução da despesa pública como forma de reforçar o papel do setor privado na economia.
} 
legitimidade aos governos que atuam de forma seletiva respondendo as reivindicações e pressões da sociedade.

Fazendo referência a Política Social, o projeto neoliberal se utiliza do papel do Estado como sendo um Estado mínimo, que significa corte nos programas sociais, introduzindo no cenário social, a focalização, o fim da universalidade e seu desmonte, ou seja, retirando-se do campo dos direitos sociais.

Como exemplo desse modus operandis, observamos hoje quanto o Estado privilegia o pagamento da dívida externa em detrimento das políticas sociais (respondendo aos mandos do neoliberalismo), tão caras a classe trabalhadora.

A tendência do neoliberalismo é reestruturar os programas sociais através da descentralização, que visa aumentar a eficiência e a eficácia do gasto.

Soares (2003) nos lembra que:

A filantropia substitui o direito social. Os pobres substituem os cidadãos. A ajuda individual substitui a solidariedade coletiva. O emergencial e o provisório substituem o permanente. As micros soluções ad hoc substituem as políticas públicas. O local substitui o regional e o nacional. (Soares, 2003)

No contexto da globalização, as políticas sociais são percebidas, como a focalização no indivíduo e não mais nos direitos. Nesse processo, surge a desigualdade. Analisando esta conjuntura se percebe a diminuição do emprego formal e a não universalização dos direitos.

De acordo com Faleiros,

[...] política social não é ajuda, piedade ou voluntariado. Mas o processo social, pelo meio o qual o necessitado gesta consciência política de sua necessidade e, em consequência, emerge como sujeito de seu próprio destino. Dessa forma, deixa de ser objeto e se torna sujeito ativo. Assim, para ser definida de social precisa atingir a concreta redução da desigualdade, sendo, portanto, de cunho emancipatório. (Faleiros, 1996, p.26).

Com o ajuste neoliberal, não se afeta apenas a esfera econômica, mas redefine globalmente o campo político institucional e das relações sociais. Tal ajuste neoliberal foi denominado por Soares como desajuste social, pois, além de agravar a já existente desigualdade social fez surgir novas formas de exclusão social. No decorrer deste processo de desresponsabilização do Estado com as políticas sociais começam a surgir as organizações públicas não estatais chamadas 
de terceiro setor, encarregadas de promover a assistência social conforme, o modelo de programa Comunidade Solidária ${ }^{10}$.

Percebe-se assim, que a cidadania na verdade não está completa, como exemplo o caso da cidadania regulada ${ }^{11}$. Devido às conjunturas políticas ser caracterizada pela desproteção social e não pela implementação de políticas sociais plenas, a cidadania não existe no seu termo real.

Com a política neoliberal ditando as regras da dominação capitalista sobre o Estado, este tende a se desresponsabilizar de suas obrigações no que tange a garantia dos direitos sociais ao cidadão, anulando a referida emancipação. Sua atuação assim, se transfigura através de programas de solidariedade que mobilizam recursos empresariais e da própria sociedade para implementar políticas que atendam precariamente as necessidades da população.

[...] o novo assistencialismo, a nova filantropia que satura as várias iniciativas estatais/privadas mediante as chamadas "parcerias público-privado" - que configuram as políticas sociais implementada desde os anos 1980-90 para enfrentar o quadro da pauperização contemporânea, isto é, da "questão social", velha e/ou nova. Já não se está diante da tradicional filantropia (de base confessional e/ou laica) que marcou os modelos de assistência social que emergiram no século XIX nem, muito menos, diante dos programas protetores ou de promoção social que vieram a institucionalizar-se a partir do Estado de Bem-Estar-Social. (Netto, 2012, p.428)

Netto, afirma que:

A política social dirigida aos agora qualificados como excluídos se perfila reivindicando-se como inscrita no domínio dos direitos, enquanto específica do trado-capitalismo: não tem nem mesmo a formal pretensão de erradicar a pobreza, mas de enfrentar apenas a penúria mais extrema, a indigência - conforme seu próprio discurso pretende confrontar-se com a pobreza absoluta (vale dizer, a miséria extrema). O minimalismo dessa proposição - gritante se comparado aos objetivos, aliás, nunca alcançados, dos programas de proteção/promoção social, elaborados e implementados [...]. (Netto, 2012, p.413)

\footnotetext{
${ }^{10}$ O Programa Comunidade Solidária foi instituído pelo Decreto ${ }^{\circ} 1.366$ de 12 de janeiro de 1995, para o enfrentamento da fome e da miséria. Até dezembro de 2002, o Programa esteve vinculado diretamente à Casa Civil da presidência da República e foi presidido, pela então primeira dama Ruth Cardoso.

${ }^{11}$ Cidadania construída no Brasil a partir de 1930 que estipulava regras e pré requisitos para a aquisição de direitos de cidadão. Eram cidadãos aqueles que tinham qualquer ocupação reconhecida e definida na lei. Os que não possuíam profissão regulamentada não eram considerados cidadãos e recebiam amparo da assistência social, que era realizada através das igrejas e da filantropia. (Werneck, M.)
} 
O instituído desta política social ignora quem é portador de direitos sociais e que a precariedade que se vive hoje é fruto do sistema dominante que além de acumular a riqueza global, ainda nos tira o que foi histórica e duramente conquistado. Para este, não resta outra opção a não ser aceitar seu papel de excluído e buscar na precarização do trabalho os meios para sua sobrevivência.

Um protótipo de um desenvolvimento quantitativo e qualitativo nas políticas sociais brasileiras, principalmente na necessidade de enfrentamento ao processo de acumulação capitalista surge, porém de forma insuficiente. O aumento da pauperização, inerente a esse processo, evoca novas e velhas dificuldades na implementação dessa política.

A inserção dos já conhecidos ditames liberais, disfarçados em novas roupagens não são suficientes para dar conta da complexidade dos efeitos colaterais do capitalismo sobre os diversos segmentos sociais. É crucial ilustrar como as políticas sócias podem ser necessárias para o enfrentamento das contradições do sistema. Lembrando dos limites e possibilidades que se apresentam como soluções para as crises da sociedade capitalista: financeira, produtiva e social.

Referem-se a questões de diferentes esferas e práticas para aqueles que fazem parte do campo social. Como atores principais ou coadjuvantes. Não esquecendo que a questão social, conforme já referido neste trabalho, e suas múltiplas expressões "são resultados da exploração do capital sobre o trabalho de forma aguda, vivenciada pela reestruturação produtiva e pela sua financeirização" (Iamamoto, 2006).

Todavia, tais interpretações requerem uma atenção mais profunda nas relações e estruturas políticas de poder na utilização e multiplicação das formas de intervenção social. A redefinição do papel do Estado e as novas organizações sociais.

A formulação, implantação e acompanhamento das políticas sociais contemporâneas, pela sociedade e por seus profissionais, constituem-se reforço para o avanço na condução e compreensão dessa intervenção na atual fase do capitalismo, dado o aspecto político, desafios e as dificuldades postas nas dimensões da vida social e política brasileira.

Um real processo de desenvolvimento é necessário para a construção de um projeto que abarque as necessidades concretas dos indivíduos usuários destas 
políticas. "A exploração do trabalho, pelo capital e o mais recente regime de acumulação construído, não são mais capazes de gerir a crescente estratificação da sociedade e, tampouco, de atender às necessidades mínimas da massa crescente de desempregados, subdesempregados e trabalhadores informais" (Netto, 2012).

A desqualificação do Estado tem sido a pedra-de-toque do privatismo neoliberal e sua defesa do estado mínimo.

A realidade brasileira da política social é a privatização do público: adoção de critérios de mercado nas políticas sociais. Subordinação das decisões públicas à lógica do capital empresarial (retorno financeiro). Transferência da tarefa de fornecimento para organizações empresariais privadas. Privatizações, como o caso da privatização do dinheiro, isto é, utilização de fundos para financiar o setor privado; particularização dos programas sociais, que são incentivos às empresas para o fornecimento de provisões, cuja contrapartida do governo seria deduzir impostos e contribuições; desinvestimentos do setor público. (Werneck, 2012, p. 91-114.

Ressaltamos o momento em que, as políticas sociais são substituídas por programas de combate à pobreza, que possuem características tais como a dependência de recursos externos e o caráter transitório, a substituição da universalidade pela focalização e o autofinanciamento.

Jose Paulo Netto (2012) complementa o desenho desse momento definindoo com propriedade:

[...] o projeto neoliberal restaurador viu-se resumindo no tríplice mote da "flexibilização" (da produção, das relações de trabalho), da "desregulamentação" (das relações comerciais e dos circuitos financeiros) e da "privatização" (do patrimônio estatal). Se esta última transferiu ao grande capital parcela expressivas de riquezas públicas, especial, mas não exclusivamente nos países periféricos, a "desregulamentação"b liquidou as proteções comercial alfandegárias dos Estados periféricos mais débeis e ofereceu ao capital financeiro a mais radical liberdade de movimento, propiciando, entre outras consequências, os ataques especulativos contra economias nacionais. Quanto a "flexibilização", embora dirigida principalmente para liquidar direitos laborais conquistados a duras penas pelos vendedores de força de trabalho, ela também afetou padrões de produção consolidados na vigência do taylorismo fordista. (Netto, 2012)

De fato o chamado "mercado de trabalho" vem sendo radicalmente reestruturado - e todas as "inovações" levam à precarização das condições de vida da massa dos vendedores de força de trabalho: a ordem do capital é hoje, reconhecidamente, a ordem do desemprego e da "informalidade". 
Uma verdade se impõe, não é com a privatização e com o mercado livre que os agudos problemas do desemprego e desagregação social serão resolvidos. Entrega-los aos braços do mercado, mais que um contrassenso, é optar pelo retorno a insegurança social.

De qualquer modo, é legitimo afirmar que, independente de modificações e diferenciações, o anseio por bem-estar põe em questão a economia de mercado. Restando-nos continuar lutando pela democratização do acesso à riqueza social.

Para ilustrar de modo simples, vemos que a história da humanidade é feita de lutas e conquistas, de recuos e de avanços. Crescimento econômico é fundamental, mas políticas sociais são imprescindíveis do ponto de vista das classes trabalhadoras e excluídos. É preciso indagar quanto aos interesses que comparecem à arena de lutas em torno das políticas sociais e econômicas capitalistas. Questão fundamental: qual direção se dá às decisões, opções, ações e investimentos do Estado, em face de que compromissos? Em defesa de que direitos?

"Em pinceladas muito largas este é o perfil que a sociedade "tardo-burguesa se apresenta na abertura do século XXI." As transformações societárias configuraram uma serie de inequívocas "vitorias” do grande capital” (Netto 2009, p.81).

Nesse contexto que a sociedade se implica, onde evidentemente, seu papel vai além de uma fase demarcada pelo espaço com o Estado e começa a interagir em conselhos de políticas (Tatagiba, 2002; 2004) bem como em projetos que abarcam a obrigatoriedade da implementação das políticas públicas.

Durante o rápido processo de urbanização, sendo em grande parte um país rural na década de 1940 e passando a ter mais de $80 \%$ de sua população vivendo em cidades no final do século XX, (Santos, 1987) no processo de deslocamento do campo para a cidade, a população de baixa renda foi excluída de direitos e alocada em grandes capitais, em bairros com pouco ou sem nenhum tipo de serviço público. Esse histórico demonstra a organização do povo brasileiro para lutar por serviços públicos, sendo uma das origens da sociedade civil brasileira.

Assim, durante a primeira fase de organização da sociedade civil, podemos notar dois fenômenos: o crescimento quantitativo do número de associações voluntárias lidando com a organização dos pobres e a participação de seus atores 
na implementação de políticas públicas. Este argumento, que vale tanto para o início da democratização quanto para a sua fase posterior, expressa uma nova correlação de forças entre a sociedade civil e o Estado. $\mathrm{O}$ segundo fenômeno envolve a ideia de que a sociedade civil pode lidar com políticas públicas de forma independente do Estado.

Os dois movimentos radicalizaram a ideia da autonomia social e tiveram forte influência neste período. No entanto, existe um divisor de águas entre a reivindicação de autonomia do Estado nesta primeira fase (1977-1985) e a reivindicação de autonomia durante a segunda fase (1985 até hoje): a Assembleia Nacional Constituinte e o engajamento dos atores da sociedade civil em uma nova fase redefiniram intensamente a ação da sociedade civil e motivou um novo conceito de autonomia. A sociedade civil brasileira também é formada por grupos de associações fortemente ligadas ao Estado na implementação de políticas públicas.

É impossível compreender a sociedade civil brasileira sem analisar os dois grupos ao mesmo tempo. Associações que lidam com as políticas públicas são associações constituídas na maioria das vezes por grupos da classe média, localizados em algumas cidades brasileiras. Devemos considerar a ampla gama de atores e objetivos que constituem a sociedade civil brasileira como uma instituição pluralista.

Os novos comportamentos políticos da sociedade civil brasileira ajudaram a modificar o padrão de associação no país. O Brasil fez uma transição difícil de um país com uma forte tradição de privatismo para um país com várias tradições políticas, entre elas a tradição de associações da sociedade civil independentes. Recuou do autoritarismo à democratização limitada e, após o processo constituinte, para uma democracia participativa. Associações voluntárias no Brasil, na verdade, interagem tanto com o Estado como com partidos políticos. Entretanto, a interação não tem mais o significado de um controle exercido pelo Estado, tal como ocorreu durante o período populista.

Faleiros nos lembra que "O Estado não se encontra fora ou acima da sociedade, mas é atravessado pelas forças e lutas sociais que condicionam a articulação das exigências econômicas e dos processos em cada conjuntura" (Faleiros, 1995, p.57). 
Em outro sentido, segundo Vieira, não há como separar Estado de sociedade. Não é o Estado que cria a sociedade, pelo contrário, é determinada sociedade que cria determinado Estado, expressando nele suas ralações de poder, suas injustiças e seus preconceitos. Entender esta sociedade, segundo o autor, é entender as múltiplas determinações em que a reprodução desta sociedade está situada (Vieira, 1992).

Não há como esgotar considerações e reflexões sobre um tema tão dinâmico e complexo. Cabe aos profissionais que trabalham nesta área desvelar suas nuances e garantir sua efetivação.

O processo de reflexão, nesse contexto de crítica, é relevante para um melhor entendimento das questões inerentes a estas políticas econômicas e sociais contemporâneas que deixam marcas profundas em nossa sociedade.

Para além dos aspectos aqui relacionados, acresce-se nos últimos anos, as dificuldades enfrentadas pelo país na implementação da democracia, acompanhadas de constantes desafios político-econômicos que demandam, sem dúvida, um esforço de reflexão sobre o que está sendo implementado no Brasil em se tratando de "políticas públicas neoliberais". Portadora de uma letalidade social.

Nesse sentido, é necessário chamar a atenção às ações desenvolvidas pela sociedade civil brasileira, que de todas as formas buscam sobremaneira por seus direitos, e descobrir as formas pelas quais ela interage com o Estado. É onde se encontra como exemplo, as redes de apoio aos egressos do sistema penal, preenchendo o hiato ente ambos para melhor responder as demandas a elas apresentadas. O que nos remete a uma frase de Robert Castel: "A liberdade sem proteção pode levar à pior servidão: a da necessidade”.

Esse tema guarda íntima relação com a representação social negativa que reina sobre o universo carcerário no Brasil. Instituições nacionais e internacionais chamam a atenção para a necessidade da implementação de políticas públicas para o segmento carcerário. São em sua maioria, pessoas pobres e extremamente estigmatizadas que precisam mais de assistência que de punição.

É importante ter em mente que a ideia de "ressocialização" expressa na Lei de Execuções Penais indica a realidade de um sistema e de uma sociedade que não sabe o que fazer com seus criminosos nas cadeias e fora delas, e principalmente quando em liberdade. 
Sem pretender vitimizar as pessoas que cometem algum delito, contudo, é conhecido por todos que as leis brasileiras não se aplicam igualmente para todas as classes sociais. O que falta em nosso sistema de segurança pública é a união de várias políticas, como por exemplo, a educação.

Esse cenário, apenas será superado mediante a formulação de uma Política Social capaz de articular programas e recursos, associada à revisão do atual modelo de política econômica, concentrador de renda e fortalecedor das desigualdades sociais. Caso contrário, a política social brasileira não será capaz de ter o impacto sobre a extrema pobreza que tanto é tanto esperada por todos. 


\section{3 \\ Debate sobre Rede}

\section{1.}

\section{Redes Sociais e Rede de Movimentos Sociais}

Como definição básica, o termo rede origina-se do latim retis, é definido como "o entrelaçamento de fios com aberturas regulares, capazes de formar uma espécie de tecido"- (dicionário da língua portuguesa). A partir da noção de entrelaçamento, a palavra rede ganhou novos significados.

As redes podem ser também de diferentes tamanhos. De uma equipe que trabalhe em rede a uma rede de escolas, de comunidades, até uma rede internacional. Podem existir redes de redes e dentro de uma mesma rede, podem se formar outras redes, com objetivos específicos e que executem ações conjuntas.

As ações conjuntas poderão ter atividades de tipos diferentes, que se apoiem e se complementem. As ações políticas que combinem diferentes tipos de ação podem ter uma força muito maior do que aquelas desenvolvidas através de um único tipo de atuação.

Para se constituir uma rede formal, seus membros precisam ter claramente o seu objetivo. Uma rede está sempre aberta à entrada de novos membros que aceitem as regras estabelecidas, ainda que as mesmas devam ser revistas à medida que a rede vá realizando seus objetivos ou definindo novos objetivos.

$\mathrm{O}$ autodesligamento de qualquer um de seus membros não deve ser um problema, para que cada um possa ser livre em suas escolhas de, permanecer ou não como membro da rede.

No processo de desenvolvimento do capitalismo, com suas crises e o necessário ajuste dos processos de produção, as políticas sociais passam também a ser reconfiguradas. Nesse sentido, com a reestruturação produtiva, a gestão pública e a implementação das políticas sociais adquirem um novo modelo. A relação entre Estado e sociedade se altera, de forma que uma das questões que passam a ter relevância é a gestão social em rede. Nesse sentido, o Estado adota como estratégias, a descentralização e o trabalho em rede. 
Através do discurso da gestão em redes, pretende-se assegurar a efetividade das políticas públicas, mais conhecidas por ações setoriais, desarticuladas e centralizadoras.

A rede de atendimento socioassistencial tem como um dos seus objetivos principais dar o apoio e proteção social, destinados aos usuários dos serviços sociais, que devem receber dessa rede, orientação e contribuição para efetivação de seus direitos.

Deste modo, a partir da estrutura referente ao atendimento em rede, pode-se perceber uma possibilidade que alarga o exercício da cidadania nas suas diferentes formas, assim como os atendimentos sociais passam a ganhar novos significados. As Redes Sociais, não substituem o papel de provedor do Estado.

Uma instituição pública ou privada tem que ter conhecimento do que é feito pelas outras organizações, para poder acionar ou encaminhar o usuário que atende para outros serviços de atendimento social. O cidadão, sujeito de direitos, que chega para ser atendido em uma situação de vulnerabilidade social, apresenta um conjunto variado de necessidades sociais.

Segundo Menicucci (2002), O atendimento em rede deverá levar em conta as limitações, as possibilidades estruturais e institucionais das conjunturas nos diferentes níveis ou esferas de programas que constituem projetos federais, estaduais ou municipais, tendo como objetivo maior a qualidade do atendimento prestado ao usuário dos serviços sociais e a despersonalização das ações dos profissionais envolvidos, passando-as ao patamar da institucionalização, pois, só assim, efetivam-se os direitos sociais dos usuários, entendendo esse usuário como sujeito de direitos inteiro, ou seja, ele não é pontual, fragmentado e separado em partes. Isto quer dizer que, as necessidades sociais do usuário não existem segmentadas, separadas.

As ações pontuais e desarticuladas (contrário de intersetorialidade) não conseguiram alterar a dinâmica das vulnerabilidades sociais, a que os usuários dos serviços sociais ficam sujeitadas.

A perspectiva de rede estabelece novos parâmetros que deveriam contribuir na humanização do atendimento aos seus usuários. Essa nova perspectiva, exige que seja ultrapassado a linha da intervenção para além da atenção imediata, abrangendo o patamar dos direitos sociais e da promoção humana, que cabe ao papel do Estado. A Rede contribui com a melhoria dos atendimentos. 
A construção da história das políticas sociais é feita por omissão ou ação, porém, deve compreender a integralidade do ser humano. A rede de atendimento social não só é possível como imprescindível à efetiva conquista da integração das políticas sociais.

Dessa forma, Junqueira (2000) defende que as redes são estratégias de gestão social sob os princípios de intersetorialidade e descentralização capazes de congregar pessoas de uma mesma base territorial com o objetivo de resolver os problemas sociais que os afetam de maneira integrada, representando uma alternativa de desenvolvimento social.

A intersetorialidade como um novo paradigma de gestão para política públicas é um caminho já sinalizado pela Lei Orgânica da Assistência Social (LOAS - Lei 8.742/ 1993): “A Assistência Social realiza-se de forma integrada às políticas setoriais, visando o enfrentamento da pobreza, à garantia dos mínimos sociais, ao provimento de condições para atender contingencias e à universalização dos direitos sociais".

Segundo Menicucci, a formação de redes:

Ganha proeminência na perspectiva da intersetorialidade, principio de acordo com a qual a necessidade de estabelecer vínculos, relações entre organizações, mediadas por atores, se justifica pela necessidade de entender de maneira compartilhada a realidade social. (Menicucci, 2002)

Segundo Couto (2010), pensar a rede socioassistencial requer ir além da compreensão e das ações que foram ou não adotadas para implementar a estratégia de gestão em rede, porém também requer analisar a emergência das redes enquanto proposta mais viável para gestão da assistência social no território e o contexto político e socioeconômico de desenvolvimento das mesmas.

Amaral (2007) enfatiza que as redes manifestam um desejo coletivo de inovação quanto às formas de organização política, numa desorganização consciente e intencional de estruturas que não mais correspondem às demandas e aspirações do grupo; revelam a existência de problemas que não conseguem ser resolvidos através das antigas estruturas e formas de gestão.

O desenvolvimento do trabalho em rede possibilita alcançar a efetividade $\mathrm{e}$ complementação das políticas municipais e estaduais frente à complexidade da 
situação de pobreza e desigualdade sociais demandadas pelos atores sociais. Ainda para Amaral (2007):

(...) gerir uma dinâmica de opostos implica abordagens dialéticas e dialógicas, em conseguir conviver com contradições sem cair no erro da simplificação, em buscar a descentralização, o desejo de colaboração e a capacidade para enfrentar a novidade. (Amaral, 2007, p.2)

O conceito de redes indica a ação de organizações e pessoas que atuam sobre um mesmo objetivo. Sua formação está associada à cooperação no sentido de obter uma atuação eficiente, tendo como característica o fortalecimento de grupos que tem ideais comuns.

Quando pessoas e/ou entidades se unem para realizar determinado objetivo, elas precisam se organizar. Segundo Whitaker (2007), a estrutura de organização mais adotada é a piramidal. Uma estrutura em pirâmide corresponde: as pessoas ou entidades se organizam em níveis hierárquicos, cada nível compreendendo menos integrantes do que o nível que lhe é inferior.

Outra estrutura de organização que vem sendo cada vez mais experimentada e a estrutura horizontal em rede. Ainda segundo o autor, a estrutura em rede - que é uma alternativa à estrutura piramidal - corresponde: seus integrantes se ligam horizontalmente a todos os demais, diretamente ou através dos que os cercam.

Embora as redes muitas vezes surjam como reação a problemas que se criam com as pirâmides, elas não pretendem necessariamente substituir ou se contrapor às estruturas piramidais.

A estrutura em rede pode ser mais favorável à realização dos objetivos. Os fios que dão consistência a uma rede são as informações que transitam pelos canais, que interligam seus integrantes. Inclusive podem se organizar redes com o único objetivo, de intercâmbio de informações.

Segundo Castells (1999), o modelo que ele denomina de "informacional", a fonte de produtividade se baseia na tecnologia de geração de conhecimento, de processamento da informação e de comunicação de símbolos em que a informação é o ponto principal na organização social e o fluxo de mensagens compõe o encadeamento da estrutura social. Tal realidade forneceu as bases para expansão das redes. 
Como as redes não comportam centros ou níveis diferentes de poder, a livre circulação de informações, torna-se assim uma exigência essencial para o bom funcionamento de uma rede. Todos os seus membros têm que ter acesso a todas as informações que nela circulem.

Conforme Scherer-Warren (1999), a noção de rede refere-se a uma estratégia de ação coletiva, baseada numa cultura solidarística, cooperativa, horizontalizada e mais democrática para uma nova forma de organização da sociedade. Ainda na apreensão da autora, as redes relacionam-se com o tecido social, isto é com o sistema social e com as relações preexistentes.

Essa articulação será direcionada a uma questão que demanda intervenção seja ela governamental ou não. Nesse caso será formada uma rede de movimento social em que sociedade civil e o governo apresentarão propostas para a resolução da questão.

Para os autores McCarthy e Zald,

Uma organização de movimento social é uma organização complexa ou formal, a qual identifica seus objetivos a partir das referências de um movimento social ou um contra movimento e se esforça para implementar aqueles objetivos" (McCarthy, Zald, 1997, p.1218 apud Carlos, 2011).

A rede será caracterizada pela autonomia e interdependência nas relações entre as organizações participantes. Nas suas ações articulam diferentes tipos de recursos o que permite um maior alcance dos serviços. E o interessante nesse movimento de união é permitir dar visibilidade ao que se está defendendo.

A grande variedades de redes sociais presentes na estrutura de ação coletiva, são quase sempre ignoradas pelos estudiosos de movimentos sociais e apenas mais recentemente o interesse pela relação entre movimentos sociais e redes sociais tem crescido (Diani, 2003 apud Carlos, 2011).

A análise de redes sociais tem como premissa que os laços sociais estabelecidos pelas pessoas, atores coletivos, organizações e instituições, constituem o elemento por excelência de estruturação da vida social.

Como defende Diani (2003 $3^{\mathrm{a}}$ p.6), a perspectiva de rede pode iluminar diferentes dinâmicas que são essenciais para a compreensão empírica dos movimentos, permitindo a apreensão da multiplicidade de níveis de experiência usualmente encontrada em processos de ação coletiva e mobilização de base. 
O conceito de rede tem sido utilizado para definir um novo modelo de ação. Apesar de o conceito ser trabalhado por diferentes abordagens, é considerado um conjunto de pontos conectados, em que cada um desses pontos representa uma diversidade de atores: organizações governamentais e não governamentais, comunidades, empresas, dentre outros, que vão determinar o tipo de rede que se caracteriza, os interesses, objetivos e valores compartilhados.

Teixeira (2006) na sua definição enfatiza o aspecto flexível das redes a formação de redes e a construção de parcerias formam um modelo de geometria variável. As alianças são múltiplas, flexíveis e orientadas para a ação. Cada parceiro traz para a agenda comum suas vantagens comparativas e seu valor agregado.

O trabalho em rede precisa mais do que a intencionalidade de trocar uns com os outros, mas a formação de uma estrutura orientada para uma ação a partir da construção de um planejamento, de definição de objetivos e de onde se quer chegar.

Assim deve ocorrer, com as redes de atendimento, com objetivos em comuns, com foco nos resultados e na vida dos usuários atingidos por essas ações. A seguir apresentaremos a rede de atendimento aos presos e a egressos do sistema penitenciário.

\section{2.}

Rede de Atendimento: debate reflexivo do atendimento dentro da prisão

Para entendermos o papel da Rede socioassistencial, na vida dos egressos do sistema penitenciário, é preciso compreender o perfil deste público e suas complexidades. Antes de apresentarmos as questões sociais enfrentadas pelos egressos frente à inserção na sociedade, e a assistência a eles destinada, se faz necessário analisarmos a assistência prestada pelo Estado aos presos.

A pessoa presa é definida como usuária, da política pública de Proteção Social Especial de Alta Complexidade (PNAS, 2004). A Proteção Social Especial de Alta complexidade garante a proteção integral aos usuários e/ou famílias que se encontram em situação de abandono e/ou com seus vínculos familiares e 
comunitários rompidos. Tais fenômenos ocorrem por motivos complexos e multideterminados. Um destes motivos é a privação de liberdade, a reclusão ou cárcere.

Em 1984, foi estabelecida a Lei de Execução Penal (LEP), Lei 7.210, visando regulamentar a classificação e individualização das penas, indicando conceitos para tratamento do condenado, procurando resguardar seus direitos, instituindo seus deveres e dar ênfase à humanização do sistema penitenciário e também incentivar a opção da utilização das penas alternativas.

Atualmente, os órgãos responsáveis pela Execução Penal ${ }^{12}$ são: o Conselho Nacional de Política Criminal e Penitenciáriai ${ }^{13}$; o Juízo da Execução ${ }^{14}$; o Ministério Público ${ }^{15}$; o Conselho Penitenciário ${ }^{16}$; os Departamentos Penitenciários $^{17}$; o Patronato ${ }^{18}$; o Conselho da Comunidade ${ }^{19}$; a Defensoria Pública $^{20}$.

Assim como há a especificidade de cada órgão da execução penal há também a conceituação e classificação dos Estabelecimentos Penais ${ }^{21}$. Com a finalidade de compreender essa conceituação segue:

a) Estabelecimentos Penais: todos aqueles utilizados pela Justiça com a finalidade de alojar pessoas presas, quer provisórios quer condenados, ou ainda aqueles que estejam submetidos à medida de segurança;

b) Estabelecimentos para Idosos: estabelecimentos penais próprios, ou seções ou módulos autônomos, incorporados ou anexos a estabelecimentos para adultos, destinados a abrigar pessoas presas que tenham no mínimo 60 anos de idade ao ingressarem ou os que completem essa idade durante o tempo de privação de liberdade;

\footnotetext{
${ }^{12}$ Segundo Art. 61 da LEP.

${ }^{13}$ Integrado por 13 membros designados pelo Ministério da Justiça e órgão subordinado a ele. Composto por equipe multidisciplinar e participação popular.

${ }^{14}$ Compete aplicar a pena.

${ }^{15}$ Responsável pela fiscalização da execução da pena e medida de segurança.

16 Órgão consultivo e fiscalizador da execução da pena composto por equipe incluindo representantes da comunidade. Completando esse ano, 90 anos de serviços prestado.

${ }^{17}$ Subordinados ao Ministério da Justiça é órgão executivo da Política Penitenciária Nacional e de apoio administrativo e financeiro do Conselho Nacional de Política Criminal Penitenciária.

${ }^{18}$ Público ou particular destina-se a prestar assistência aos albergados e aos egressos.

${ }^{19}$ Composto por 1 representante da sociedade civil, 1 advogado da OAB, 1 Defensor Público e 1 Assistente Social, são incumbidos de visitar os estabelecimentos penais, entrevistar os presos e apresentar relatórios ao Juiz da execução e ao Conselho Penitenciário.

${ }^{20}$ Zela pela regular execução da pena e medida de segurança.

${ }^{21}$ Disponível em http://portal.mj.gov.br
} 
c) Cadeias Públicas: estabelecimentos penais destinados ao recolhimento de pessoas presas em caráter provisório, sempre de segurança máxima;

d) Penitenciárias: estabelecimentos penais destinados ao recolhimento de pessoas presas com condenação à pena privativa de liberdade em regime fechado;

d.1) Penitenciárias de Segurança Máxima Especial: estabelecimentos penais destinados a abrigar pessoas presas com condenação em regime fechado, dotados exclusivamente de celas individuais;

d.2) Penitenciárias de Segurança Média ou Máxima: estabelecimentos penais destinados a abrigar pessoas presas com condenação em regime fechado, dotados de celas individuais e coletivas;

e) Colônias Agrícolas, Industriais ou Similares: estabelecimentos penais destinados a abrigar pessoas presas que cumprem pena em regime semiaberto;

f) Casas do Albergado: estabelecimentos penais destinados a abrigar pessoas presas que cumprem pena privativa de liberdade em regime aberto, ou pena de limitação de fins de semana;

g) Centros de Observação Criminológica: estabelecimentos penais de regime fechado e de segurança máxima onde devem ser realizados os exames gerais e criminológicos, cujos resultados serão encaminhados às Comissões Técnicas de Classificação, as quais indicarão o tipo de estabelecimento e o tratamento adequado para cada pessoa presa;

h) Hospitais de Custódia e Tratamento Psiquiátrico: estabelecimentos penais destinados a abrigar pessoas submetidas à medida de segurança.

Na Lei de Execuções Penais - LEP - em seu Art. $1^{\circ}$ está disposto que “A execução penal tem por objetivo efetivar as disposições de sentença ou decisão criminal e proporcionar condições para a harmônica integração social do condenado e do internado".

No Art. $10^{\circ}$, a LEP torna visível que "A assistência ao preso e ao internado é dever do Estado, objetivando prevenir o crime e orientar o retorno à convivência em sociedade". Embora nos deparamos coma falta de estrutura, que passa pela arquitetura prisional e a falta de profissionais qualificados, para essa orientação do preso, à sua saída do cárcere.

Segundo a LEP, para tal são fornecidas assistência: 
Material: que consiste no fornecimento de alimentação, vestuário e instalações higiênicas. Assistência à saúde: de caráter preventivo e curativo, atendimento médico, farmacêutico e odontológico. Jurídica: é destinada aos presos e aos internados sem recursos financeiros para constituir advogado.

A Assistência Educacional: compreende a instrução escolar e a formação profissional do preso e do internado. Social: tem a finalidade de amparar o preso e o internado e prepará-los para a liberdade. E Religiosa - liberdade de culto, permitindo a participação nos serviços organizados no estabelecimento penal, assim como a posse de livro de cunho religioso.

Até Junho de 2014, segundo dados do Infopen ${ }^{22}$, a população carcerária no país era composta de 607.731 pessoas, sendo $94 \%$ de homens e $6 \%$ de mulheres e $56 \%$ consistiam em jovens com menos de 30 anos de idade. No que diz respeito à cor, raça ou etnia, o sistema penitenciário era composto por negros em sua maioria com 67,1\%. De cor branca 31,3\%. 0,1\% de raça amarela, os indígenas $0,2 \%$. Outras raças e etnias composto por $0,4 \%$. Em relação ao nível de escolaridade, a maioria dos presos, em 2014, 53\% possuía o Ensino Fundamental Incompleto. 9\% eram alfabetizados, $12 \%$ possuíam o Ensino Fundamental Completo, 7\% possuíam o Ensino Médio concluído, 6\% eram analfabetos, $11 \%$ não possuíam o Ensino Médio Incompleto, $1 \%$ haviam iniciado alguma faculdade, mas não concluíram.

Dessa forma, até a metade do ano de 2014, os jovens de 18 a 24 anos eram maioria nas penitenciárias brasileiras e representavam $31 \%$ da população carcerária do País. 25\% correspondem à faixa etária de 25 a 29 anos; $18 \%$ dos presos tinham entre 30 e 34 anos; 17\% tinham entre 35 e 45 anos; $7 \%$ se encontravam na faixa etária de 46 e 60 anos; $1 \%$ estava acima de 60 anos.

A ser assim, o sistema penitenciário brasileiro vem mantendo o mesmo perfil de presos que são os jovens, pardos e de baixa escolaridade. A população carcerária do Brasil é a quarta maior população carcerária do mundo, os dados são do International Center for Prison Studies, estando atrás somente dos EUA, China

\footnotetext{
22 O InfoPen é um programa de computador (software) de coleta de Dados do Sistema Penitenciário no Brasil, para a integração dos órgãos de administração penitenciária de todo Brasil, possibilitando a criação dos bancos de dados federal e estaduais sobre os estabelecimentos penais e populações penitenciárias. É um mecanismo de comunicação entre órgãos de administração penitenciária, criando "pontes estratégicas" para os órgãos da execução penal, possibilitando a execução de ações articuladas dos agentes na proposição de políticas públicas. Os dados estatísticos apresentados, correspondem até junho de 2014.
} 
e Rússia. Fato, que existem mais de 200.000 mil presos provisórios (41\% da população carcerária) sem condenação no país ${ }^{23}$.

Atualmente, a Secretaria de Estado e Administração Penitenciária - SEAP é o órgão responsável pelo Sistema Penitenciário do Rio de Janeiro. "Foi criada através do Decreto ${ }^{\circ}$ 32.621, de $1^{\circ}$ de janeiro de 2003, com o objetivo de dar um tratamento individualizado e específico ao Sistema Penitenciário do Estado do Rio de Janeiro". E sua missão é planejar, desenvolver, coordenar e acompanhar as atividades pertinentes à Administração Penitenciária do Estado do Rio de Janeiro, no que concerne à custódia, reeducação e reintegração do preso à comunidade em conformidade com as políticas estabelecidas ${ }^{24}$. Seu lema é "Ressocializar para um futuro conquistar...”.

A SEAP possui em sua estrutura três Subsecretarias Adjuntas: Unidades Prisionais; Infraestrutura e Tratamento Penitenciário, possui também uma Subsecretaria Geral de Administração Penitenciária. A SEAP possui três Coordenações de Unidades Prisionais: Gericinó; Frei Caneca e Isoladas; e Niterói e Interior; com o objetivo de dar assistência ainda mais personalizada às direções dos presídios.

São órgãos da SEAP: Fundação Santa Cabrini ${ }^{25}$ (FSC); o Conselho Penitenciário (CONPE) e o Fundo Especial Penitenciário (FUESP). A Secretaria possui uma Ouvidoria e Corregedoria própria. O coronel da Polícia Militar, Erir Ribeiro Costa Filho ${ }^{26}$ é o secretário de Estado de Administração Penitenciária do Estado do Rio de Janeiro e foi nomeado pelo Governador Luiz Fernando de Souza - Pezão, em 20 de março de 2015.

O Estado do Rio de Janeiro possui um total de 53 estabelecimentos penais. Sendo 45 unidades masculinas, 7 femininas e uma mista. Nos anos de 1994 e 1997, a SEAP abriu concurso para o cargo de agente penitenciário. Onde eram oferecidas 500 vagas e 700 vagas respectivamente. No ano de 1998, realizou um concurso público para profissionais de nível médio técnico e nível superior -

\footnotetext{
${ }^{23}$ Levantamento Nacional de informações Penitenciárias - INFOPEN Junho 2014.

${ }^{24}$ Disponível em: http://www.rj.gov.br/web/seap

25 “A Fundação Santa Cabrini é o órgão responsável pela gestão do trabalho realizado pelos internos do sistema penitenciário do Estado do Rio de Janeiro com o objetivo de promover a ressocialização e a profissionalização do detento, facilitando sua reinserção na sociedade. Cabe à Fundação oferecer postos de trabalhos aos presos, bem como garantir a remuneração destes e a redução da pena em um dia a cada três dias trabalhados". Disponível em: www.santacabrini.rj.gov.br

${ }^{26}$ Disponível em: http://www.rj.gov.br/web/seap/exibeconteudo?Article-id=140690
} 
dentistas, psicólogos, assistentes sociais, médicos, terapeutas ocupacionais, enfermeiros e auxiliares de enfermagem. Sendo o único concurso destinado para profissionais das áreas citadas para o sistema penitenciário do Estado do Rio de Janeiro ao longo dos últimos 30 anos. Esse ano, há previsão de mais um concurso público, com 800 vagas de Inspetor de Segurança.

Outro aspecto a ser ressaltado, é ocupação dos cargos de direção e assessoria no que diz respeito à esfera hierárquica da SEAP/RJ - as Subsecretarias, assessorias e algumas direções de unidades. Observamos que é prioridade nas ações da SEAP o investimento humano em segurança, ao invés do tratamento e atendimento ao interno e na preparação da saída do pré-egresso. Todo o preso quando condenado se torna um pré egresso, sua saída tem que ser pensada, a partir de sua chegada, através da assistência devida que deveria acontecer, por meio do acesso a educação, ao trabalho e a documentação civil...

Até o mês de junho do ano de 2014, no Estado do Rio de Janeiro a população carcerária era composta de 39.321 mil presos. Sendo sua maioria cumprindo os seguintes regimes: 18.031 presos provisórios ${ }^{27}$; 12.209 no regime fechado e 8.613 no semiaberto. Enquanto dados da Secretaria da Justiça mostra que o total de vagas oferecidas pelo Sistema Penitenciário do Rio de Janeiro é de 20.602 vagas, sendo 8.790 para presos provisórios, 6.342 vagas para o regime fechado e 5.470 para o regime semiaberto, estima-se um déficit de 19 mil vagas, da população carcerária excedente. Nos dias atuais, segundo dados da SEAP, esse número chega a 43.307 presos no Estado do Rio de Janeiro, sendo 19.380 de presos provisórios, sem condenação.

Outro dado que chama atenção é que em todo Brasil, apenas uma em cada dez pessoas privadas de liberdade, realiza atividade educacional. Há no país 38.831 internos envolvidos em atividades educacionais. Esse número corresponde a $10,7 \%$ da população carcerária brasileira.

Segundo informações do DEPEN, existem 58.414, pessoas privadas de liberdade que trabalham. Em cada 10 pessoas que trabalham apenas 3, exercem atividade fora do estabelecimento penal, extramuros. A média nacional é de $16 \%$

\footnotetext{
${ }^{27}$ Presos que estão aguardando julgamento. Em muitos casos os presos provisórios ficam detidos por tempo indefinido. Sendo assim, o preso provisório acaba sofrendo os mesmos ônus que um preso definitivo.
} 
(O Estado do Rio de Janeiro e São Paulo, não forneceram esses dados para o relatório).

No ano de 2013, somente $2 \%$ dos detentos do Estado do Rio de Janeiro exerciam alguma ocupação (DEPEN, 2013). Segundo a Fundação Santa Cabrini, são dados incompletos, pois não abrangem os presidiários que trabalham como faxinas (classificados dessa forma, os internos que trabalham como auxiliar de serviços gerais e de administração) nas unidades prisionais. Acrescidos esses casos, o total de presidiários trabalhando intramuros ultrapassaria o número de 2.200 mil detentos o que corresponde a 5\% da população carcerária.

Todavia, mesmo levando em consideração os dados apresentados pela Fundação Santa Cabrini, o estado do Rio de Janeiro continua com um dos quatro menores contingentes de trabalhadores no sistema penitenciário brasileiro. Outros três estados do Brasil (até junho de 2014) têm menos de $10 \%$ de seus presos realizando atividade laboral: Paraíba 9\%, Rio Grande do Norte 3\% e Sergipe $3 \%{ }^{28}$.

Através do conteúdo extraído do site do Ministério da Justiça, podemos afirmar que a LEP tem como o seu objetivo basilar a (re) socialização pelo trabalho, bem como através da qualificação profissional. No entanto, o trabalho intramuros pode ser considerado como outra forma de penalização do individuo, pois se para um homem que está em liberdade o trabalho acabou se tornando um suplicio no sentido de que o salário que recebe não é o suficiente para seu sustento, tão pouco para o preso, onde na prisão, o trabalho é utilizado como forma de educar o preso para as mais variadas formas de exploração de sua força de trabalho. Não obstante, o trabalho intramuros não é uma oportunidade dada a todos os presos, se tornando também, uma maneira do preso responder as autoridade que o objetivo da instituição está sendo correspondido, no que diz respeito a "recuperação" do indivíduo.

Segundo Foucault:

O trabalho pelo qual o condenado atende a suas próprias necessidades requalifica o ladrão em operário dócil. E é nesse ponto que intervém a utilidade de uma retribuição pelo trabalho penal; ela impõe ao detento a forma "moral" do salário como condição de sua existência [...] A utilidade do trabalho penal? Não é um lucro; nem mesmo a formação de uma habilidade útil; mas a constituição de uma

28 http://agenciabrasil.ebc.com.br/noticia/2013-01-05/rio-de-janeiro-tem-menor-indice-de-presostrabalhando-entre-todos-os-estados 
relação de poder, de uma forma econômica vazia, de um esquema da submissão individual e de seu ajustamento a um aparelho de produção. (Foucault, 1987, p. 217)

No que diz respeito à assistência educacional, observa-se que o Rio de Janeiro apresenta um dos índices mais baixo, 0,5\% de detentos estudam dentro das unidades. A quantidade de internos envolvidos em atividade educacional, é de aproximadamente 207 internos. Em alfabetização, Ensino Fundamental, Ensino Médio, Cursos Técnicos e Ensino Superior. Porém, o Rio de Janeiro sai na frente nesse aspecto, sendo o único estado brasileiro que possui escolas públicas, estaduais dentro das unidades penitenciárias.

O Exame Nacional de Ensino Médio - ENEM, criado em 1998 em todo o Brasil, entrou nas unidades prisionais aproximadamente em 2010, com a instituída ENEM PPL - Pessoas Privadas de Liberdade. Nos dias atuais os presos do Estado do Rio de Janeiro, em regime semiaberto que passam em vestibulares, encontramse com dificuldades de acesso a esse direito, lhes sendo negada a liberação para frequentar a universidade. Hoje existe uma demanda apresentada por internos a VEP, de solicitações para essa liberação. Com atrasos nessas liberações, isto significa novas reprovações e desistências.

$\mathrm{Na}$ Assistência Religiosa, dos anos 90 em diante predominou-se e predomina os evangélicos no interior das unidades, com celas separadas só para eles e cultos frequentes, com grupos que lhes oferecem suportes.

Porém, do ponto de vista da maioria dos internos, algumas pessoas se utilizam da "palavra", pois grande parcela deles tem algum problema que pode dificultar sua vida no coletivo. Problemas estes como estupro, atentado violento ao pudor, envolvimento com grupo de extermínio, ou algo que ocorreu em algum outro coletivo, caracterizado como grave do ponto de vista da vida interna no cárcere. Mas isso não ocorre com a maioria dos internos que ali se encontram. Muitos realmente estão buscando uma nova vida. Um verdadeiro encontro com Deus. (Relato de um interno do regime semiaberto - Outubro de 2014).

A Igreja Católica vem em seguida, desenvolvendo seu trabalho de evangelização, e de apoio espiritual celebrando missa e outros auxílios pertinentes aos seus adeptos sem restrições coletivas. Tendo em vista que a maioria das Unidades Prisionais possuem capelas ecumênicas para os encontros e realizações de eventos. Nos anos 90, com Padre Bruno Trombeta a frente da Pastoral Penal 
(hoje Pastoral Carcerária) havia uma participação mais efetiva dos agentes pastorais nas assistências religiosas e materiais para os internos.

Kardecistas também usufruem dos espaços no interior das unidades prisionais, sem nenhum problema interno ou restrições. Porém ainda de forma muito tímida.

Já a Umbanda, o Candomblé e outros de matrizes africanas, no início dos anos 90, ainda existia vestígio em algumas Unidades Prisionais, mas vem perdendo forças ao longo dos anos, por motivos de preconceito contra a religião.

Também por motivos de falta de estrutura e espaços apropriados que possam realizar o culto a sua crença. Necessitam muitas vezes do contato com a natureza, plantas, águas e animais. O que dentro do sistema é inviável (Relato de um agente pastoral - Outubro de 2014).

A Assistência Religiosa no sistema penitenciário é de certa forma um tanto complexa, por motivo de horários dos cultos, locais para a realização de eventos e outras razões que envolvem a segurança na prisão. Contudo, de forma muito tímida, esse direito tem sido garantido aos apenados.

Acerca do direito a assistência material, o Estado diz suprir toda necessidade dos presos. Porém sabe-se das existências ilegais de cantinas dentro das unidades, onde os presos compram do Estado seus materiais de higiene, limpeza e alimentação.

Tanto na assistência jurídica, como no serviço social, percebemos a falta de profissionais e equipes para atenderem ao efetivo das unidades. Em algumas unidades existe apenas um técnico de cada área para atender a população que varia de 1.000 a 1500 , por unidade. Isso inclui também os profissionais de psicologia e saúde.

Dentro deste contexto, apesar de todos os avanços obtidos, obsevamos que diante da atual realidade do sistema penitenciário brasileiro há disparidade entre a normatização e o que se efetiva na prática. É possível verificar que a prisão não reeduca se tornando assim um dispositivo punitivo e que em sua maioria das vezes funciona como agravante para inserção social. A saber, a superlotação nas unidades prisionais, as condições insalubres e os maus tratos são exemplos de que a efetivação da reinserção social se encontra em xeque. Um fato que evidencia tal 
análise foi o episódio em que o Ministro da Justiça José Eduardo Cardozo ${ }^{29}$ relatou que: "Infelizmente, os presídios no Brasil ainda são medievais. E as condições dentro dos presídios brasileiros ainda precisam ser muito melhoradas. Entre passar anos num presídio do Brasil e perder a vida, talvez eu preferisse perder a vida, porque não há nada mais degradante para um ser humano do que ser violado em seus direitos humanos” (2013). “[...] A realidade dos presídios em todo país e no Rio de Janeiro é o retrato fiel de uma sociedade desigual e da ausência de uma política setorial séria e estruturada que enfrente a ineficiência do sistema penitenciário [...]" (Costa, 2012, p. 6).

Não apenas no Rio de Janeiro, mas em todo o Brasil existe um "culto" a privação da liberdade e quase tão somente voltada para os sujeitos que praticam delitos e que tem uma inserção de classe econômica baixa. Sendo assim, nosso sistema penitenciário nos faz alusão de quem é preso no Brasil e não necessariamente é um apontador do perfil daqueles que cometem crime.

Cabe então questionar, quais são os interesses envolvidos na sustentação do sistema penitenciário, ou se o Estado e a sociedade manifestam real interesse em sua transformação. Pois esta é uma temática em que toda a sociedade precisa refletir, uma vez que todos estão de uma forma ou de outra, seja direta ou indiretamente, envolvidos nessa questão.

Muito se discute, nos dias atuais, a devida (re) inserção social de egressos do sistema penitenciário a sociedade, esquecendo-se no entanto, que essa inserção tem sua base construída enquanto o indivíduo se encontra em privação de liberdade. Durante o cumprimento de penas restritivas de liberdade, o Estado tem a possibilidade de orientar, capacitar e fomentar a cultura da qualificação profissional de maneira mais próxima, fazendo com que, ao sair, o preso ou internado se torne um egresso consciente de seus direitos e capacidades e tenha possibilidades reais de uma harmônica integração social. Ou pelo menos deveria ser, já que sabemos que existem verbas destinadas no Fundo Penitenciário Nacional, mas que não são utilizados pelos Estados. Ou por falta de interesse em pensar políticas efetivas para o atendimento ao preso e de assistência ao egresso, ou por não conseguirem planejar ações que apenas envolvam segurança.

\footnotetext{
${ }^{29} \mathrm{http}$ ///oglobo.globo.com/pais/ministro-diz-que-prefere-morrer-passar-anos-em-cadeiasbrasileiras-6718740
} 


\section{3.}

\section{Assistência ao Egresso}

O nome "egresso" do sistema penitenciário, traz uma carga negativa, tornando-se um estigma. Goffman (1975) conceitua estigma como um atributo profundamente depreciativo, atribuído pela sociedade com base no que constitui uma "diferença" ou "desvio". Essa diferença ou desvio acontece com base nas normas estipuladas pela sociedade tidas como normais. Quem foge a estas regras passa a possuir uma identidade deteriorada aos olhos da sociedade.

O egresso do sistema penitenciário, após o período de reclusão, retorna a sociedade em busca do resgate de sua cidadania e necessita do apoio de familiares e amigos e de instituições /ações, que possibilite o seu acesso a serviços que viabilize a sua inserção social.

Além da baixa escolaridade, o egresso ainda enfrenta a questão do estigma e preconceito por ser ex-presidiário. A falta de qualificação profissional está atrelada à discriminação como um fator de dificuldade a sua inserção no mercado de trabalho formal, ressaltando o fato de algumas empresas realizarem a pesquisa criminal para não ter no seu quadro de empregados um ex-apenado. Uma clara atitude preconceituosa, que vai de encontro ao artigo III, dos princípios da PNAS - no que diz: "Respeito à dignidade do cidadão, à sua autonomia e ao seu direito a benefícios e serviços de qualidade, bem como à convivência familiar e comunitária, vedando-se qualquer comprovação vexatória de necessidade".

A (re) inserção social é um processo que deveria se iniciar no Sistema Penitenciário, tendo continuidade quando o preso se torna egresso. Thompson aponta, como a grande contradição das prisões.

Para a mulher esse processo ser torna ainda mais doloroso e solitário. Quando presas carregam o estigma e preconceito em todas as formas. São em maioria, pardas ou negras e pobres, acusadas de tráfico de drogas, que muitas vezes tem relação com o companheiro. E logo que são presas, são abandonadas por estes homens, sem visitas e tem que deixar seus filhos com familiares.

Hoje no Brasil, segundo relatório do DEPEN, existem cerca de 37.380, mulheres presas. A população carcerária feminina aumentou, no período de 2000 
a $2014,567,4 \%$, mais que o dobro do aumento que teve a população masculina no mesmo período, aumento de $220,20 \%$.

Segundo Fagherazzi, o sistema prisional tenta promover o aspecto da readaptação social, reinserção social, reeducação e inclusive o uso impreciso da própria ressocialização, todos caracterizados pelo prefixo (re). O autor ainda afirma que a institucionalização não poderá ter um efeito ressocializador.

Defende-se a ideia que tratar a exclusão social é tratar simultaneamente de inclusão social. Estes conceitos são enquadrados no âmbito da "problemática da equidade" e da "problemática do conhecimento" e atuam como um mapa para compreender como as políticas são postas em prática.

A primeira, a problemática da equidade, coloca a mudança social na ação racional do ator social. A inclusão social e a exclusão social são conceitualizadas como duas entidades diferentes, nas quais o objetivo é produzir inclusão social e eliminar a exclusão social "de determinados grupos de atores sociais, tais como aqueles definidos por classe, sexo, raça ou etnia" (Sposati, 2006).

De modo que a assistência ao egresso, segundo a Lei de Execução Penal, consiste: na orientação e apoio para reintegrá-lo à vida em liberdade; na concessão se necessário, de alojamento e alimentação, em estabelecimento adequado, pelo prazo de dois meses. Esse prazo pode ser prorrogado uma única vez, desde que comprovado por declaração do assistente social, o empenho na obtenção de emprego. O serviço de assistência social colaborará com o egresso para a obtenção de trabalho. (LEP - Art. 25, 26 e 27). São serviços que deveriam ser efetivados, já que estão previstos em Lei. Porém, não é o que acontece na maioria dos casos, e a regra acaba virando exceção.

A discriminação, o estigma e a falta de trabalho na vida das pessoas que cumpriram pena privativa de liberdade levam por fim a exclusão social. Oliveira diz, que a exclusão é resultado da "não integração no mundo normal do trabalho, desnecessidade econômica e, em consequência, a possibilidade de serem eliminados". (apud Siqueira, 2001, p. 57).

Toda forma de exclusão advém da privação de algum serviço essencial para condição humana. Com a apropriação privada e a falta de políticas distributivas de renda existe uma tendência a aumentar a exclusão social, pois aumentará o número de desempregados e marginalizados socialmente (Siqueira, 2001, p.57). Diante disso, os egressos do Sistema Penitenciário, na condição de 
desempregados, são duplamente excluídos: primeiro porque são ex-detentos e segundo porque estão fora do mercado.

A exclusão no mercado de trabalho completa-se sempre na exclusão social. Nascimento (1994) pontua que os novos excluídos são marcados pelo desemprego ou incapacidade de renda: um grupo social economicamente desnecessário, politicagem incomodo e socialmente ameaçador.

A elaboração de trabalho é um dos fatores mais importantes no processo de (re) inserção social. Seja no trabalho formal ou autônomo. Forti (2005) relata que: "O trabalho é atividade vital para a assistência humana, atividade que a constitui e a caracteriza, fonte de satisfação das necessidades do ser humano e a sua possibilidade histórica".

A Assistência ao trabalho é um dos direitos mais importantes, se não o maior, para a inserção social do egresso. "O primeiro ato histórico pelo qual podemos distinguir os homens dos demais animais não é o de pensarem, mas o de começarem a produzir os seus meios de vida" (Marx \& Engels, 1984, p. 14).

Ao longo dos últimos anos, a qualificação profissional tem sido a principal ferramenta utilizada no âmbito da reintegração social para inclusão no mercado de trabalho e geração de renda para presos, internados e egressos ${ }^{30}$.

Com a efetivação da LEP, os egressos passam a ter respaldo legal. Mas a concretização a partir da formulação de políticas públicas focalizando-os, ocorrerá de forma iniciante, em meio à década de 90, através de iniciativas dos poderes públicos municipais, estaduais e sociedade civil, onde são implantados programas visando sua reinserção social com uma atuação baseada no trabalho, escolarização, profissionalização e saúde. Assim, acabam obtendo importância em âmbito federal por órgãos do Ministério da Justiça, tais como o Conselho Nacional de Política Criminal e Penitenciária $(\mathrm{CNPCP})^{31}$, Secretaria de Reinserção Social e do Departamento Penitenciário Nacional ${ }^{32}$ (Depen). Todos com a intenção do desenvolvimento de uma política mais abrangente de apoio a egressos no Brasil.

No campo Federal, a preocupação com egressos originou-se de práticas designadas como ações de (re) inserção social, estas, possuem a intenção de

\footnotetext{
${ }^{30}$ Disponível site DEPEN: Infopen.

${ }^{31}$ Tem o seu foco na orientação das políticas em nível intelectual.

${ }^{32}$ Incumbido por aspectos práticos, tais como o financiamento para a construção de novos presídios.
} 
instituir conexão entre Estado, sociedade e pessoas beneficiadas, com o objetivo de ampliação da resiliência e redução da vulnerabilidade em face ao sistema penal. A partir da atuação da sociedade civil, dos poderes públicos, entidades privadas e organizações do terceiro setor, os programas de apoio ao egresso do sistema penitenciário propõem-se à reinserção social e a redução de índices de reincidência. Para isto, suas atuações são fundamentadas na LEP.

Destacam-se ainda, de acordo com os princípios constitucionais, aqueles previstos na constituição federal de 1998: "Art. 6 São direitos sociais a educação, a saúde, a alimentação, o trabalho, a moradia, o lazer, a segurança, a previdência social, a proteção à maternidade e à infância, a assistência aos desamparados, na forma desta Constituição".

Art. 203. A assistência social será prestada a quem dela necessitar, independentemente de contribuição à seguridade social, e tem por objetivos:

III - a promoção da integração ao mercado de trabalho.

As ações de apoio a trabalho e renda, enquanto políticas públicas, podem ser consideradas parte de uma política de trabalho, pois afetam diretamente o mercado de trabalho, elevando o nível de ocupação e permitindo que os trabalhadores desenvolvam suas capacidades laborais durante a participação em um empreendimento.

Quanto à natureza de tais atividades, é necessário destacar que programas, projetos, ou ações de geração de trabalho e renda possuem como principal objetivo resolver um problema ou, mais especificamente uma carência social. Por este motivo, estas iniciativas devem ser consideras de natureza social.

Ainda neste contexto, podemos citar a $\mathrm{PNAS}^{33}$ que visa à garantia dos mínimos sociais e a universalização dos direitos sociais, provendo serviços, programas, projetos e benefícios de proteção social básica e/ou especial para os indivíduos ou famílias que dela necessitarem. Dessa forma,

Constitui o público usuário da política de Assistência Social, cidadãos e grupos que se encontram em situações de vulnerabilidade e riscos, tais como: famílias e indivíduos com perda ou fragilidade de vínculos de afetividade, pertencimento e sociabilidade; ciclos de vida; identidades estigmatizadas em termos étnico, cultural e sexual; desvantagem pessoal resultante de deficiências; exclusão pela pobreza e, ou, no acesso às demais políticas públicas; uso de substâncias psicoativas; diferentes formas de violência advinda do núcleo familiar, grupos e indivíduos;

\footnotetext{
${ }^{33}$ Política Nacional de Assistência Social, 2004.
} 
inserção precária ou não inserção no mercado de trabalho formal e informal; estratégias e alternativas diferenciadas de sobrevivência que podem representar risco pessoal e social. (PNAS, 2004)

Os egressos do sistema penitenciário se caracterizam como usuários da política de assistência social, pois são pessoas em risco social, com perda ou fragilidade de vínculos de afetividade, identidades estigmatizadas e pertencem a um grupo social que se encontra em situação de vulnerabilidade social.

A inserção social é um processo árduo, pois apesar de existirem dispositivos legais que a garanta, poucas instituições realizam de fato um trabalho com tal perspectiva, para este segmento da sociedade.

Segundo Madeira, “...defendemos que tais indivíduos tiveram processos de socialização, que os incluíram em uma cultura de violência, sendo necessário, então, todo um processo de ressocialização que os retire a possibilidade de resolução de conflitos, de aquisição de bens materiais e de obtenção de prestígio social, via violência" (2004).

Consideramos que inserção social é o processo que ocorre na perspectiva de melhoria na qualidade de vida e na garantia de acesso a direitos, de segmentos como o egresso e pré-egresso, que na maioria das vezes, não tiveram oportunidades e tiveram sim os seus direitos constitucionais negados.

Para que haja a inserção social é necessário um trabalho em conjunto com todas as esferas da sociedade, quer pública, privada ou iniciativas de terceiro setor. É necessário que haja uma transformação do posicionamento da sociedade em relação ao preso e ao egresso que dificilmente são reconhecidos como indivíduos de direitos. É necessário também que haja efetivação de fato das políticas públicas voltadas para este segmento, bem como a ampliação de dessas políticas, pois Costa $(2012$, p. 7,8$)$ afirma que:

Outro problema que atinge a raiz do sistema prisional do Rio de Janeiro é a escassez de política pública penitenciária no sentido de reduzir ou prevenir a reincidência ao crime e a violência, a estigmatização do indivíduo que cumpre ou já cumpriu pena, inclusive políticas públicas direcionadas para o atendimento dos egressos prisionais e seus familiares. (Costa, 2012, p. 7-8)

A realidade em liberdade parecerá distinta para o egresso, logo encontrará dificuldades, tornando o apoio necessário. Entretanto, não se deve contar apenas com o trabalho do Estado, de maneira isolada, todavia também com os grupos 
como família, comunidade, trabalho, enfim, a sociedade. Portanto, é cogente haver uma mudança social.

A assistência é direito do liberado da justiça, instituída na LEP. Deste modo, devemos avançar pela garantia dos direitos já definidos. Direito a saúde, a educação, a habitação, ao lazer, ao trabalho digno, direito de ir e vir, de liberdade de expressão... Respeitando o que consta do Artigo $5^{\circ}$ da Constituição Federal Brasileira que diz:

“TODOS SÃO IGUAIS PERANTE A LEI, SEM DISTINÇÃO DE QUALQUER NATUREZA...”. A Constituição Federal de 1988 é o marco jurídico da transição para a democracia e da institucionalização dos direitos humanos no Brasil. Os direitos sociais foram expandidos e a disciplina da Ordem Social, cujos objetivos são o bem-estar e a justiça-social. Os diversos princípios de natureza liberal, ampara a atuação normativa e reguladora do Estado.

Um dos maiores desafios da sociedade moderna é assistir ao homem que enfrenta os problemas advindos do encarceramento, quer durante o cumprimento da pena de prisão, quer após esta, quando devolvido à liberdade.

De nada adianta todo o esforço para melhorar o sistema prisional brasileiro, se ao libertar o homem, a sociedade o rejeita, o estigmatiza, o repugna e o força a voltar à criminalidade, em sua maioria por absoluta falta de opção.

O Estado e a sociedade devem encarar o problema e buscar soluções urgentes quebrando esse total desinteresse pelo egresso. Não é preciso ressaltar a importância do tema, mas indispensável fixar a ideia do que e de quem produz o egresso, estabelecendo de onde ele vem.

É através da liberdade e do trabalho que o egresso reconstrói sua cidadania. No direito à vida em liberdade. Por consequência, não devemos esquecer a conjunção entre o direito à vida e o direito à liberdade, que está presente no artigo $3^{\text {o }}$ da Declaração Universal dos Direitos do homem: "cada indivíduo tem direito à vida, à liberdade e à segurança" 34 .

Cabe aos patronatos públicos ou particulares o serviço de assistência ao Egresso ( $\operatorname{art}^{\circ} 78$ da LEP). Segundo as Regras Mínimas da ONU, as atividades desses órgãos sejam tanto quanto possível centralizadas e coordenadas, a fim de que possa ser assegurada a melhor utilização possível de seus serviços $\left(\mathrm{n}^{\circ} 81\right)$.

\footnotetext{
${ }^{34}$ BOBBIO, Norberto. A Era dos direitos. Rio de Janeiro: Elsevier, 2004.
} 
No Estado do Rio de Janeiro, contamos com o Patronato Magarinos Torres, para assistência ao egresso. O Patronato é órgão do Poder Executivo do Estado do Rio de Janeiro, pertencente à SEAP, subordinada a Subsecretaria de Adjunta de Tratamento Penitenciário. É uma instituição pública destinada a realizar o cumprimento dos benefícios penais: Liberdade Condicional, ${ }^{35}$ Sursi, Prisão Albergue Domiciliar e Monitorada, Limitação de final de Semana e Prestação de Serviço a Comunidade. Sua sede está localizada em Benfica, e possui dois polos de atendimento: em Campos e Volta Redonda.

Há seis anos, a direção do Patronato mudou a forma de atuação e atendimento ao egresso. Realizou duas ações pró egresso, com o objetivo de unir instituições públicas e privadas que prestam assistência em diversas áreas, para atendimento aos egressos e internos, nas ares de saúde, educação, documentação civil, encaminhamentos para trabalho e atendimento jurídica e social.

Em outubro de 2014, o Patronato diante das mais diferentes questões que envolvem o processo de acompanhamento aos egressos do Sistema Penitenciário e condenados a Penas Alternativas e dos desafios que as instituições que os assistem enfrentam. Promoveu o I Congresso Nacional de Acompanhamento a Egressos e Afins, que se revestiu de grande importância, pois se tratou de uma grande oportunidade para a discussão e conhecimento de estudos e experiências voltadas para a (re)socialização das pessoas que cumprem penas restritivas de direitos. Reuniram nesse evento, órgãos da Execução Penal, internos, egressos, autoridades envolvidas na temática, organizações governamentais e não governamentais, estudantes, pesquisadores, universidades, conselhos e empresários, com o objetivo de que a sociedade se fizesse representar para criação de uma rede nacional, a fim de ampliar as ações enquanto gestores de políticas públicas e cidadãos, objetivando a redução da reincidência criminal.

\footnotetext{
${ }^{35}$ Sursis é uma suspensão condicional da pena, aplicada à execução da pena privativa de liberdade, não superior a dois anos, podendo ser suspensa, por dois a quatro anos, desde que: $\mathrm{O}$ condenado não seja reincidente em crime doloso; A culpabilidade, os antecedentes, a conduta social e personalidade do agente, bem como os motivos e as circunstâncias autorizem a concessão do benefício; e não seja indicada ou cabível a substituição por penas restritivas de direitos. É medida de política criminal no Código Penal Brasileiro, que tem o fim de estimular o condenado a viver, doravante de acordo com os imperativos sociais cristalizados na lei penal, de onde logicamente para ser concedido é necessário haver convicção de que não haverá perigos à sociedade.
} 
Durante os três dias de eventos surgiram algumas Propostas apresentadas à Plenária, das seguintes sessões:

\section{Sessão de Saúde}

- Proposta de participação dos conselhos de saúde distrital, municipal e estadual no controle e fiscalização da saúde no sistema prisional diante da política nacional de saúde no sistema penitenciário.

- Verbas para medicação;

- Atenção biopsicossocial e espiritual para os servidores;

- Anexo do Hospital Prisional voltado ao tratamento em dependência química no município de Campos dos Goytacazes;

\section{Sessão de Educação}

- Auxiliar o poder judiciário a desburocratizar as ações de inclusão nas universidades e demais instituições de ensino;

- Buscar a implementação do curso a distância e estendê-lo aos presos dentro das unidades prisionais, inclusive graduação - EAD;

- Incentivar através de uma rede as frentes que estão sendo desenvolvidas pelos egressos;

- Resolução específica para arquitetura penal que prestigie os espaços para educação e tratamento de todos os reclusos. Se uma prisão tem mil reclusos o espaço para o estudo deve contemplar 500 pessoas em cada turno, em um turno o preso trabalha e no outro estuda.

- Incluir nas escolas que funcionam nas unidades prisionais profissionais de serviço social, psicologia e médicos;

- A criação do Plano Estadual de Educação em Prisões;

- Implementações de escolas dentro da Unidade Prisional com independência financeira e pedagógica, possuindo recursos humanos imprescindíveis para o funcionamento de qualquer escola, como coordenação pedagógica, diretor, corpo funcional administrativo, professores, entre outros;

- A implementação do Projovem Urbano no universo prisional feminino de Campos dos Goytacazes; 
- A ampliação do acesso aos presos e presas ao Ensino Superior, devendo ao Conselho Nacional Penitenciário, o Conselho Nacional de Educação e o Conselho Nacional de Justiça construir normas, condições e critérios para que estes sujeitos tenham a possibilidade de ingressar nas Universidades;

\section{Sessão de Aporte Jurídico}

- Criar fórum para compartilhar experiência;

- Melhorar e reconhecer os direitos políticos;

- Abolir a revista vexatória;

- Abolir ou aperfeiçoar o exame criminológico;

- Vedar exame criminológico para crimes menos violentos;

- Rediscussão sobre o sistema de monitoramento (GPS/Banda larga) confiabilidade no sistema;

- Promover concursos entre escolas de tecnologia para criação de modelo de monitoramento menos constrangedor e limitante;

- Atenção especial à documentação;

- Verba exclusiva para a mobilidade dos presos em regime de semiaberto e aberto.

- A efetivação do Conselho de Comunidade;

\section{Sessão de Assistência Social e Civil}

- Investir na capacitação do interno durante o cumprimento de pena visando à inserção no mercado de trabalho;

- Facilitar o credenciamento e reconhecimento das organizações sociais, independentes de serem religiosas que desejem ofertar trabalhos e oferecer assistência aos presos e egressos; Atenção aos dependentes químicos nos hospitais prisionais;

- Proposta de empregabilidade para quem está cumprindo penas alternativas;

- Agilização da documentação civil;

- Organização de mais congressos e outras atividades que discutam essas questões;

- Formação dos ISAPS (inspetor de segurança e administração penitenciária) articulada com respeito ao preso e aos direitos humanos; 
- Rever o critério de apresentação do PAD (prisão albergue domiciliar) de 15 em 15 dias;

- Propiciar agilidade para apuração de denúncias do executivo no MP (Ministério Público);

- Atender as propostas voltadas para as demandas específicas das mulheres bem como dos presos estrangeiros;

- Desvinculação dos patronatos do sistema prisional;

- Verifica-se a necessidade de o Estado investir em campanhas, programas e projetos que promovam um debate público acerca do modelo de prisão que o país necessita.

\section{Sessão de Mercado de Trabalho}

- Criar grupos para acompanhamento das políticas de egressos em níveis municipais, estaduais e federal, com a criação concomitante de conselhos da comunidade.

- Influenciar Projetos de Lei para a contratação da mão de obra de internos e egressos, em empresas privadas e terceirizadas por órgãos públicos.

\section{Sessão de Políticas Públicas}

- Criar patronatos regionais com recursos das penas pecuniárias, através dos conselhos das comunidades e de parcerias privadas que possam sustentar a política de inclusão do egresso - Paraná e Foz de Iguaçu;

- Para os estados que não tem patronatos e nem intenção de fazê-lo sugerimos que façam patronatos privados - Bahia

- Mais audiências públicas para sensibilizar o governo federal para destinar mais verbas para ampliação dos patronatos, com o intuito de ampliar o atendimento ao egresso e a população - Mato Grosso do Sul.

- Capacitar os profissionais e voluntários para a participação nos conselhos de direitos humanos.

- Haja integração, visibilidade e parcerias entre as pessoas e instituições engajadas na causa do egresso;

- Criar uma rede de amigos ou simpatizantes envolvidos com a causa do egresso. 
Diante das propostas apresentadas, verificamos que ainda há muito por fazer para a implantação de políticas de melhorias para o tratamento e atendimento aos internos, e assistência ao egresso no sistema penitenciário.

Os Estudos apontam, que investindo $\mathrm{R} \$ 50,00 \mathrm{em} 1$ egresso, a probabilidade de reincidir é de $15 \%$. O Estado gasta mais de $\mathrm{R} \$ 2.000,00$ com um preso por mês e a taxa de reincidência é de 80\%”. (Maurício Kuehne - advogado, ex diretor do Departamento Penitenciário Nacional e professor de Direito Penal. 2014).

A LEP dispõe, em seu artigo $1^{\circ}$, que o objetivo fundamental da execução penal é "proporcionar condições para harmônica integração social do condenado e internado". Não é o que de fato acontece. A prestação do dever estatal, no âmbito da inserção social, deveria traduz-se em ações que promovam a elevação da escolaridade, a assistência aos apenados, egressos e internados, bem como a profissionalização, integração ao mercado de trabalho e geração de renda.

O Estado opta em investir em segurança, sendo muito mais oneroso aos cofres públicos e pouco efetivo na preparação da saída e do retorno a vida em liberdade. O Estado não possui interesse em mudar essa realidade e a sociedade não colabora para a inserção social das pessoas encarceradas. 


\section{4 \\ O Trabalho em Rede}

\section{1. Rede de Apoio ao Egresso do Sistema Penitenciário - RAESP}

A RAESP é a Rede de Apoio ao Egresso do Sistema Penitenciário, que tem suas ações desenvolvidas no território, do Estado do Rio de Janeiro. Criada em maio de 2006 através de iniciativas de algumas instituições, com o foco na importância da pluralidade e interdisciplinaridade para alcançar objetivos comuns - melhores condições para a inserção social de egressos.

Fazem parte da constituída Rede:

O Banco da Providência, criado em 1959, por Dom Hélder Câmara, em sua luta na promoção da justiça social, para os excluídos e na valorização das pessoas enquanto promotores de oportunidades para suas vidas de forma a transformá-las. Desde 1975, desenvolve ações para pessoas que cumprem penas privativas de liberdade. Desde 2010, atua na formação, capacitação, apoio psicossocial e acompanhamento, na geração de renda, para a inserção de mulheres e homens, através do Projeto Agência da Cidadania.

A Fundação Santa Cabrini, fundada em 1977, é um órgão vinculado à Secretaria de Estado de Administração Penitenciária - SEAP, responsável pelo gerenciamento do trabalho prisional, intra e extramuros. Serviços ofertados: atividades laborativas, cursos de qualificação, capacitação profissional, oportunidade de emprego e regularização da documentação civil.

O Centro de Integração Social e Cultural - CISC /uma chance, tem a sua origem criada em 2003, por um egresso do Sistema Penitenciário, com a marca de promover o empreendedorismo junto aos egressos do Sistema de forma a garantir autonomia na sua atividade produtiva, como alternativa ao mercado formal. Recentemente conseguiu financiamento junto a Petrobrás para o desenvolvimento de suas atividades junto aos egressos, bem como aos adolescentes em cumprimento de medida sócio-educativa. Ampliando sua atuação em outros estados da federação e se consolidando cada vez mais na área do 
empreendedorismo. Com consultoria, pela Fundação Getúlio Vargas. Serviços ofertados: capacitação para o mercado de trabalho, atendimento social, psicológicos, orientação jurídica e auxílio para regularização de documentos.

O Instituto de Cultura e Consciência Negra Nelson Mandela, fundada por um egresso do Sistema, quando ainda estava encarcerado, em 1989, voltada para a defesa dos direitos dos presos, com atuação na área jurídica, sinalizando as injustiças e discriminações sofridas pelos internos e egressos, no cumprimento de pena e na busca de inserção no mercado de trabalho. Serviços ofertados: atendimento jurídico, atendimento social, encaminhamento ao mercado de trabalho e palestras.

A Pastoral Carcerária, pertencente à Arquidiocese do Rio de Janeiro, que atualmente passa por alteração de direção, atuando quanto às demandas apresentadas e discutido formas para avanços na conquista de direitos, dos egressos e internos. Atualmente possui cadastrados, cerca de 65 agentes pastorais, que fazem um trabalho religioso e de assistência material, dentro das unidades.

O Instituto Manancial da Vida, formado por egressos, com o objetivo de colaborar com a questão ambiental e capacitação profissional. Seu projeto principal é a reciclagem de óleo, que deu origem a cooperativa, Cooperliberdade.

Além desse grupo, também identificamos alguns profissionais que já haviam trabalhado com os internos e/ou egressos do Sistema Penitenciário: membro individual que atua na Comissão de Direitos Humanos da ALERJ, que trabalha com denúncias de atos que envolvam o abuso de poder e aviltamento dos direitos fundamentais expressos na Declaração Universal de Direitos Humanos, bem como aqueles direitos que são aviltados em face dos tratados internacionais entre o Brasil e outros países. Outro membro que atua é o Programa de Saúde da Família - PSF, para a população em situação de rua, onde homens e mulheres egressas do sistema penitenciário, também fazem parte dessa população.

O objetivo inicial da RAESP foi de colaborar com os órgãos competentes onde os egressos eram atendidos, visando unir esforços para potencializar suas ações no atendimento aos egressos do Sistema, bem como os seus familiares, na atenção voltada para o atendimento de necessidades imediatas como recursos financeiros para passagens - vale transporte, cesta básica, regularização de documentos, colocação no mercado de trabalho, qualificação profissional. 
Ao longo destes nove anos a RAESP, tem se reunido periodicamente, quinzenalmente ou mensalmente, sempre com a preocupação de discutir temas voltados aos interesses dos egressos e as necessidades para o seu retorno à sociedade.

Com o objetivo de ampliar a rede e divulgar cada vez mais as ações dos parceiros, a RAESP:

Promoveu I Seminário da RAESP em 07/10/2008 na Sede da OAB-RJ; Participou da $1^{\mathrm{a}}$. Ação Pró Egresso, promovida pelo Patronato Magarinos Torres e os parceiros da RAESP, em 06/09/2012; Participou também da 2a. Ação Pró Egresso, promovida pelo Patronato Magarinos Torres e os parceiros da RAESP, em 29/05/2013.

Temos clareza que o cumprimento de pena requer um grande sacrifício do interno e dos seus familiares. Em alguns casos é possível passar por unidades prisionais com escola, atividade de trabalho, biblioteca, que possibilitam uma capacitação durante o cumprimento de pena (Depoimento da Coordenadora da RAESP, Edite Rosa de Mesquita, 2014).

Sabemos que estas instalações não são suficientes, nem todos conseguem classificação para participação, a RAESP deseja que estes direitos sejam universalizados dentro do Sistema, o que possibilitaria um retorno à sociedade com melhor formação escolar e conhecimento profissional, pois valoriza a evolução no ensino regular e qualificação profissional em face dos impactos que podem fazer diferença neste retorno à sociedade com perspectiva de sua inserção no mercado.

A RAESP iniciou com os sete membros, e foi avançando com novos parceiros, no intuito de somar forças e juntar elementos de argumentação para convencer as autoridades de providências para fazer valer os direitos dos internos, egressos e seus familiares.

Instituições e membros que passaram a integrar a RAESP, a partir de 2009:

O Patronato Magarinos Torres - que recebe os internos desde o período de Prisão Albergue domiciliar - PAD, no seu acompanhamento quinzenalmente. Atua nos período de prova do livramento condicional, as penas de limitação de fim de semana e Alternativas. Foi idealizador e promotor do I Congresso para egressos a fim de refletir junto aos demais representantes dos Patronatos dos estados da Federação e levar uma proposta para promoção de política pública para o egresso; 
Serviços ofertados: documentação civil, acompanhamento psicossocial, encaminhamentos jurídicos, de saúde, assistenciais, educacionais, para capacitação e empregabilidade.

O Núcleo de Práticas Jurídicas - NPJ, do Departamento de Direito da PUCRio, através da pessoa da professora e advogada, Agnes Christian, firmou parceria com a RAESP, com o objetivo de prestar assistência jurídica aos internos do regime aberto e egressos do sistema penitenciário.

Membros que iniciaram na Rede a partir de 2012:

As Assistentes Sociais da SEAP - representantes da Coordenação do Serviço Social - área credenciamento de agentes religiosos, tem discutido junto a Rede, as condições de cumprimento de pena e as dificuldades de credenciamento, bem como de regularização de documentação dos internos;

Os Psicólogos da SEAP - através da Coordenação do Projeto VIDA Projeto que atua em várias unidades prisionais, na formação de internos com efeito multiplicador de informações em diversas áreas de saúde, direitos, cidadania.

Professores da rede pública de ensino, da Secretaria de Educação do Estado do Rio de Janeiro SEEDUC. Professores que dão aulas diariamente, dentro das unidades prisionais e que presenciam a todo o momento as questões enfrentadas pelos internos e as demandas apresentadas por estes.

Os Professores do Projeto do Cárcere a Universidade - UERJ, que desenvolvem um trabalho de formação universitária para aqueles que ainda no cárcere se empoderam para se tornarem profissionais de nível superior, vislumbrando a liberdade com a inserção de mercado de trabalho e formação profissional. Serviços ofertados: Apoio e assistência aos internos e estudantes em suas demandas, com administração e prazos acadêmicos e consultoria a apoio jurídico para autorização, para o estudo.

O Projeto Começar de Novo do Tribunal de Justiça - projeto do Governo Federal, através do Conselho Nacional de Justiça, viabiliza vagas no mercado de trabalho para inserção de egressos e em cursos de capacitação profissional.

Parceiros da RAESP, a partir de 2013:

Os membros individuais da Defensoria Pública; o Fórum Justiça, em que defensores públicos de vários segmentos do direito como: privados de liberdade; direitos voltados para população quilombolas; direito das mulheres, entre outros 
discutem as ausências de direitos, e de que forma podem levantar elementos que possam mudar esta realidade. No caso do egresso, ele está no grupo privados de liberdade. Neste grupo estão os encarcerados, os adolescentes em medidas socioeducativas, os internados em asilos, manicômios e instituições de cumprimento de medidas sócio-educativas (Informações concedidas, pela Coordenadora da RAESP, Edite Rosa de Mesquita, 2014).

Representantes do Conselho Penitenciário da Secretaria de Estado e Administração Penitenciaria - SEAP. O Conselho Penitenciário é órgão consultivo e fiscalizador da execução da pena. Elabora pareceres e sugere medidas sobre o sistema penitenciário no estado para as autoridades públicas estaduais. Atua nos processos de pedidos de indulto, comutação de pena. Seus membros realizam o livramento. Portanto, vêm de perto a situação em que o interno sai do Sistema Penitenciário. Neste mesmo ano, a RAESP contou com mais novos membros individuais: a assistente social do Batalhão Prisional Militar e estagiárias das faculdades de serviço social e psicologia.

Em 2014, a adesão de novos membros e parcerias:

O Centro Espírita Casa do Perdão - uma casa religião de origem africana, oferece cursos profissionalizantes e capoeira. Oferece apoio a população em situação de risco, bem como aos egressos e seus familiares.

A instituição evangélica, Convenção Batista Carioca - atua na implantação de igrejas batistas e fortalecimento de igrejas e capelanias. Atuam também em prisões e unidades socioeducativas. Serviços ofertados: aconselhamento às pessoas que se encontram em situações vulneráveis emocionalmente e espiritualmente, apoio nas áreas de saúde, educação e qualificação para o mercado de trabalho.

A associação Luz da Liberdade, presta assistência aos internos e internas dentro das unidades prisionais e aos egressos do sistema penitenciário, bem como a seus familiares. Serviços ofertados: concessões de cestas básicas, cursos de capacitação, encaminhamento para vagas de trabalho, palestras sobe saúde e cidadania.

O Instituto Amendoeiras se inseriu a RAESP, para somar esforços no atendimento e na discussão de enfrentamento das questões vivenciadas pelas mulheres internas e egressas do sistema penitenciário. Serviços ofertados: 
capacitação profissional, atendimentos educacionais, apoio psicológico e social, concessão de auxílios, passagem e alimentação.

Inserção do Laboratório de Práticas Sociais e Pesquisas sobre Violência, através de professor Doutora Lobélia da Silva Faceira e das estudantes do curso de serviço social e pesquisadoras. O LPSPV é um espaço de suporte e assistências ao egresso a ao preso em regime aberto do sistema penitenciário do Estado do Rio de Janeiro. Encontra-se sediado no Programa de Pós-Graduação em Memória Social da Universidade Federal do Estado do Rio de Janeiro - UNIRIO.

A Rede está em expansão e possui, na qualidade de seus representantes, a intenção de trabalhar conjuntamente para alterar a realidade dos egressos e presos. Trabalhar arduamente para sensibilizar as autoridades quanto às demandas dos mesmos.

A RAESP tem focado suas ações na busca de elementos para modificar a realidade dos egressos, sob os seguintes aspectos: Emissão do título de eleitor enquanto número de documento para viabilizar a inserção no mercado de trabalho formal.

O egresso que entrou no sistema penitenciário sem o título de eleitor, quando migra para o regime semiaberto, poderá receber uma carta de trabalho em uma empresa. Porém, esta empresa terá dificuldades para cadastrá-lo no PIS, pois sem o número do título de eleitor, esse cadastramento não é possível.

O Tribunal Regional Eleitoral emite uma declaração, onde aparece que o cidadão está com os direitos políticos suspensos devido à condenação criminal, constrangendo o egresso e retirando-lhe a possibilidade de inserção no mercado de trabalho formal.

A RAESP está atuando conjuntamente com o Conselho Penitenciário e este junto à instância do Tribunal Superior Eleitoral. Para que o egresso seja cadastrado e tenha um número de título de eleitor.

Outra ação em que os parceiros da RAESP apoiaram, protagonizada pelo Patronato Magarinos Torres, foi à promoção do I Congresso Nacional de Acompanhamento de Egressos e Afins, realizado em outubro de 2014, com a convocação dos representantes de todos os patronatos dos diversos estados da federação, bem como a representação do Departamento Penitenciário Nacional DEPEN, Juízes de outros estados, bem como a presença de outras autoridades e profissionais na área de cumprimento de pena e acompanhamento de egressos. 
O objetivo desse evento foi promover uma discussão ampla, sobre o cumprimento da liberdade condicional, suas possibilidades de qualificação profissional, inserção no mercado de trabalho, retomada dos laços familiares, seus limites e possibilidades.

Um elemento a ser destacado: cada parceiro da RAESP trabalha dia a dia com esta realidade através do atendimento pessoal. O que une os seus membros, é justamente a incômoda forma com a qual veem-se os direitos essenciais como educação, trabalho, saúde, convivência familiar, não serem cumpridos como está disposto na lei. Sendo assim, a luta é, de acordo com as possibilidades, para modificar esta realidade.

A participação de diversos segmentos da sociedade, seja governamental ou não governamental, da sociedade civil ou membros individuais, nos conduz a pluralidade que amplia o olhar sobre as demandas do egresso e do interno privativo de liberdade. Diferentes abordagens sobre o mesmo tema, convergindo para as necessidades de atendimento destas demandas $\mathrm{e}$ as respectivas repercussões do atendimento ou não (Edite Rosa, 2014).

Podemos dizer que nesta pluralidade, observamos a necessidade de que estes diversos atores institucionais realizem ações integradas. Por exemplo: Hoje sabemos que o interno que trabalha não estuda, ou vice-versa. Devemos elucidar junto às autoridades competentes qual a real demanda: trabalhar e estudar. A necessidade de uma interação é urgente e exige mais que vontade política, necessita que esta política atual seja repensada, nos moldes das necessidades daquele que é seu destinatário: o apenado, egressos e seus familiares.

A reflexão da intersetorialidade, ou seja, de que forma os setores se entrelaçam a fim de construir uma ação que atenda aos objetivos do apenado é fundamental para pensarmos uma alternativa àquela que existe atualmente.

Acreditamos que a partir da identificação das demandas e a construção de uma política pública de Estado, que venha a integrar os órgãos, com a participação da sociedade civil, respeitando as especificidades locais, com objetivos claros, poderíamos avançar na diminuição dos índices de reincidência e da criminalidade.

Trazer a sociedade civil para esta discussão é fundamental, pois o preso de hoje retornará a esta mesma sociedade, que hoje lhe vira as costas, e de forma muito mais violenta do que saiu, na maioria das vezes. Trabalhamos hoje com exceções. Temos que buscar a efetivação da política pública, para que os 
resultados que temos no universo carcerário passem a ser resultados da aplicabilidade de uma política pública verdadeira.

A participação dos membros da RAESP, nos espaços de debates de formulação de políticas públicas, faz parte do processo de luta deste movimento para discutir a efetivação e ampliação dos direitos de cidadania aos internos e egressos.

Também em 2014, a RAESP foi convidada a participar do I Simpósio Nacional de Políticas para a Pessoa Egressa do Sistema Prisional, realizado nos dias 04 e 05/11/2014 - em Brasília. Organizado por: Ministério da Justiça Departamento Penitenciário Nacional, na busca por novos caminhos de enfrentamento desta expressão da questão social:

Durante o evento, estiveram presentes representantes de Estado, órgãos públicos, instituições privadas, do terceiro setor, representantes da sociedade civil e representante dos egressos, para pensarem em propostas para a formulação da Política pública, com implantação prevista em todo Brasil, para 2015.

Abaixo as propostas elencadas, pelos grupos temáticos de trabalho:

1. Definição do público da Política (pré-egresso e egresso);

2. Estrutura e arquitetura (estabelecimentos penais);

3. Aumento da equipe multidisciplinar (através de concurso público para profissionais que atuem no sistema prisional);

4. Composição de Dados/“diagnósticos” (prontuário individual e seguir para outras ações, sendo esta documentação alvo de estudos).

5. Incluir o tema Sistema Prisional nas grades curriculares das universidades e na imprensa, visto que a mídia condena antes do juiz;

6. Articulação entre as políticas, os Três Poderes (Legislativo, Executivo e Judiciário) e sociedade civil;

7. Kit mínimo para o egresso, sua saída do cárcere (documentos, material de sobrevivência como roupas, vale transporte, cesta básica, cartilha com informações básicas).

Essas propostas representam as modalidades e desafios da assistência ao egresso e a importância da existência de uma Política Nacional de Assistência a Pessoa Egressa visando erradicar os fatores que levam à reincidência criminal a 
partir da (re) inserção do indivíduo no convívio social, reafirmando a ligação, inclusão social pelo trabalho e a não reincidência criminal.

Nesses quase 10 anos de existência da RAESP, a Rede de Apoio ao Egresso do Sistema Penitenciário, do Rio de Janeiro, além de agregar em sua composição instituições públicas, privada e da sociedade civil. Consolidou suas propostas de trabalho e resultados alcançados.

Alguns temas elencados nas reuniões da Rede:

- Atendimento jurídico aos egressos e internos do Sistema Penitenciário;

- Convênio com a Secretaria Estadual de Trabalho e Renda - SETRAB para promoção do trabalho para egressos;

- Propostas de alterações na Lei de Execuções Penais - Lei Federal no 7.210/84;

- Ampliação de vagas para egressos através de parcerias, como a do SECONCI - Sindicato das Empresas da Construção Civil;

- Consequências da falta do título de eleitor para o egresso do Sistema Penitenciário por ocasião da inserção no mercado de trabalho.

Eventos relevantes, que a RAESP participou no ano de 2014:

- Participação do Presidente do Instituto de Cultura e Consciência Negra Nelson Mandela - ICCNNM como membro do Conselho Estadual de Segurança Pública do ERJ e no Conselho Estadual de Direitos Humanos, da Secretaria de Estado de Assistência Social e Direitos Humanos;

- I Conferência Municipal dos Direitos Humanos;

- Cerimônia de Entrega da Medalha Tiradentes na Assembleia Legislativa do Estado do Rio de Janeiro, destinada ao Jose Carlos Brasileiro Presidente do Instituto de Cultura e Consciência Negra Nelson Mandela ICCNNM;

- Cerimônia de Entrega de Medalha Pedro Ernesto na Câmara dos Vereadores destinada à Mariângela Pavão - Diretora do Patronato Magarinos Torres;

- 25 anos do Instituto de Cultura e Consciência Negra Nelson Mandela ICCNNM; 
- Assembleia Anual dos Agentes Religiosos - Centro Diocesano de Formação - Arrozal - Volta Redonda;

- Reunião com Agente Federal - Técnico do DEPEN - Brasília em visita ao Patronato Magarinos Torres e à Fundação Santa Cabrini, para discussão sobre pontos relevantes da política nacional destinada aos egressos do Sistema Penitenciário;

- Matéria de divulgação no Canal Saúde FIOCRUZ - Programa Unidiversidade, tendo como tema as possibilidades da (re) socialização dos presos, com a presença da presidente do Conselho Penitenciário, Representantes da: COOPERLIBERDADE, Pastoral Carcerária, CISC Uma Chance, membro do Conselho Penitenciário e a RAESP;

- Palestra expositiva da RAESP na XIX FEVUC - Feira de Valores da Universidade Católica - "Direitos Humanos e as Intolerâncias: É possível dialogar nas diferenças" - promovido pela Pastoral Universitária Anchieta - PUC-Rio;

- Participação no I Simpósio Nacional de Política para pessoa Egressa do Sistema Prisional - DEPEN - Brasília;

- Participação na organização do I Congresso Nacional de acompanhamento a egressos e afins - RJ.

Acreditamos que a RAESP e seus parceiros, participantes das ações acima elencadas, se fortaleceram para a discussão de uma política pública destinada aos egressos do Sistema Penitenciário.

As propostas de ação para o ano de 2015:

Contribuir para a finalização dos procedimentos relacionados ao I Congresso Nacional de acompanhamento a egressos e afins - RJ, tais como a publicação dos anais do I Congresso; edição de documentário referente ao Congresso; bem como os desdobramentos do I Congresso e o evento do I Simpósio Nacional de Política para pessoa Egressa do Sistema Prisional, realizado em Brasília;

Promover a discussão sobre a realização de convênio com universidades para promoção da assessoria jurídica aos egressos do Sistema Penitenciário;

Organizar o III Seminário da RAESP, a ser realizado em maio/ 2016, quando a RAESP completará 10 anos de existência; 
Auxiliar na organização do I Simpósio sobre a Educação no Sistema Prisional - uma alternativa para (re) inserção social;

Os desafios apresentados a RAESP, para os próximos 10 anos:

- Ampliar o quantitativo dos parceiros garantindo a exposição das atividades dos mesmos e a divulgação entre os demais parceiros;

- Ampliar a discussão de temas em comum aos parceiros, visando apresentação de propostas;

- Promover a discussão da identidade jurídica da RAESP-RJ, ser pessoa jurídica ou não. Quais as vantagens e desvantagens de um CNPJ?

- Promover a discussão de um regimento interno, com regras sobre o funcionamento da RAESP-RJ;

- Promover a discussão sobre a criação de um site, e outras mídias de comunicação que seja um meio de divulgação, promoção e sugestões para a otimização do funcionamento da RAESP; e a criação de uma nova logomarca, que culminará com o evento de 10 anos da RAESP-RJ, em 2016;

- Apoio ao Simpósio sobre Educação nas prisões, a ser realizado com os parceiros Projeto "Do Cárcere à Universidade", UERJ - Educação; e demais parceiros da área, a ser realizado em 2016.

Nesta seção, apresentaremos os resultados e discussão dos dados obtidos através da pesquisa realizada com os membros da Rede de Apoio ao Egresso do Sistema Penitenciário - RAESP, conforme a exposição metodológica apresentada neste estudo.

Na definição de Minayo, pesquisa é uma "atividade básica das Ciências na sua indagação e descoberta da realidade". Trata-se de um "processo intrinsecamente inacabado e permanente". Em sua especificidade, a pesquisa social tem um caráter histórico e, do mesmo modo que as teorias sociais refletem 
pontos de vistas diante da realidade, etapas do "desenvolvimento e da dinâmica social, preocupações e interesses de classes e de grupos determinados. Enquanto prática intelectual reflete também dificuldades e problemas próprios das Ciências Sociais e a sua relativa juventude para delimitar métodos e leis específicas" (2000, p. 23-24).

Por metodologia, a autora contrapõe à definição de autores que a concebe apenas como um conjunto de técnicas a serem utilizadas para a apreensão da vida social. Ela amplia essa definição, afirmando que além do conjunto de técnicas que possibilitam a apreensão da realidade, a metodologia deve incluir também as concepções teóricas de abordagem e o potencial criativo do pesquisador (Minayo, 2000, p. 22).

Sobre a abordagem na pesquisa social, Minayo (2004) menciona que, "a diferença entre o quantitativo-qualitativo é de natureza". Isso porque a pesquisa quantitativa preocupa-se em apreender "dos fenômenos apenas a região visível, morfológica e concreta". No caso da abordagem qualitativa, a apreensão dos fenômenos se processa "com um nível de realidade que não pode ser quantificado". Em outras palavras, a abordagem qualitativa aprofunda-se no universo dos significados das ações e relações humanas. No entanto, “o conjunto de dados quantitativos e qualitativos, não se opõem. Ao contrário, se complementam, pois a realidade abrangida por eles interage dinamicamente, excluindo qualquer dicotomia" (2004, p. 22).

Os dados serão apresentados utilizando o recurso de gráficos e tabelas para ilustrar os resultados, destacando as variáveis de análise definidas nos objetivos propostos para esta pesquisa. Foram entrevistados para esta pesquisa, com duração de dois meses, doze (12) membros (representantes) institucionais e também, membros individuais (internos e egresso do sistema penitenciário) e a coordenadora da RAESP. 


\subsubsection{1. \\ Perfil das instituições}

Neste item, apresentaremos o perfil das instituições entrevistadas, considerando as seguintes variáveis: natureza; ano de fundação; cargo ou função do entrevistado; área da atuação, serviços ofertados e público alvo.

\subsubsection{2.}

Natureza

No que se refere à natureza das instituições, a pesquisa identificou que do total (12) de entrevistados, 33\% (04) são representantes de instituições públicas, $25 \%$ (03) são de natureza religiosa, $17 \%$ (02) ONG, e com 8,3\% cada, as instituições privadas (01), OSCIP (01) e filantrópica (01), conforme mostra o gráfico 1:

Gráfico 1- Natureza

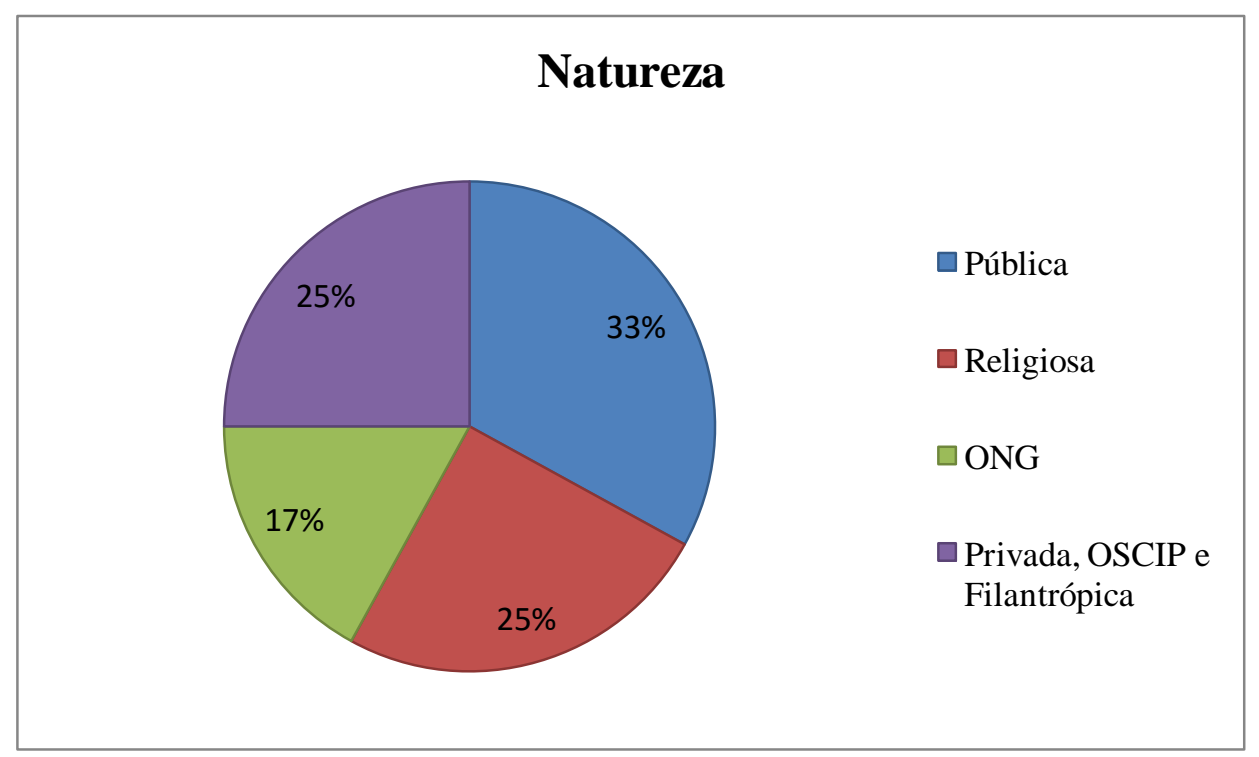

Fonte: Pesquisa realizada no mês de junho de 2015, com membros participantes da Rede de apoio ao egresso do sistema penitenciário.

Nota-se que a Rede é composta em sua maioria por instituições públicas, sendo 02 ligadas diretamente a Secretaria de Estado e Administração 
Penitenciária, 01 a Execução Penal (Tribunal de Justiça) e outra a área de Educação - Universidade do Estado do Rio de Janeiro. Seguido de instituições religiosas, de diversas crenças, sendo as evangélicas em maior número. As instituições privadas, OSCIP e Filantrópicas, empatadas, cada categoria com um representante.

Esse dado, nos indica que o a política pública voltada ao egresso, necessita do apoio da Rede e de outras instituições, para parcerias no alcance dos objetivos institucionais e implementação de projetos e programas, que o Estado não promovem.

\subsubsection{3.}

\section{Ano de Fundação}

Tabela 1 - Ano de Fundação

\begin{tabular}{||l|l|l||}
\hline ANO & ABS & $\mathbf{( \% )}$ \\
\hline Em 1903 & 01 & 8,3 \\
\hline De 1950 a 1960 & 02 & 16,6 \\
\hline De 1970 a 1980 & 02 & 16,6 \\
\hline De 2000 a 2009 & 04 & 33,6 \\
\hline A partir de 2010 & 01 & 8,3 \\
\hline Não responderam & 02 & 16,6 \\
\hline Total & $\mathbf{1 2}$ & $\mathbf{1 0 0}$ \\
\hline
\end{tabular}

Fonte: Pesquisa realizada no mês de junho de 2015, com membros participantes da Rede de apoio ao egresso do sistema penitenciário.

Percebemos que $33 \%$ das instituições que responderam essa pergunta, durante a pesquisa feita, possuem mais de 10 anos de existência. E a maioria já possui mais de 40 anos de atuação no Rio de Janeiro, com vasta experiência em atendimento ao público alvo. São instituições conceituadas, com o propósito de modificar a realidade vivenciada por internos e egressos do sistema penitenciário, contribuindo para o resgate da cidadania. Porém são instituições que precisam de financiamentos e investimentos de órgãos públicos e empresas privadas, para continuarem executando seus projetos. 


\subsubsection{4.}

\section{Cargo ou função do entrevistado}

Tabela 2 - Função do Entrevistado

\begin{tabular}{||l|l|l||}
\hline \hline CARGO /FUNÇÃO & ${ }^{\mathbf{3 6}} \mathbf{A B S}$ & $\mathbf{( \% )}$ \\
\hline Advogado & 01 & 8,3 \\
\hline Assistente Social & 02 & 16,7 \\
\hline Capelã & 01 & 8,3 \\
\hline Coordenador & 01 & 8,3 \\
\hline Diretor & 02 & 16,7 \\
\hline Gerente & 01 & 8,3 \\
\hline Gestor Institucional & 01 & 8,3 \\
\hline Membro pesquisador & 01 & 8,3 \\
\hline Presidente & 02 & 16,7 \\
\hline Total & $\mathbf{1 2}$ & $\mathbf{1 0 0}$ \\
\hline \hline
\end{tabular}

Fonte: Pesquisa realizada no mês de junho de 2015, com membros participantes da Rede de apoio ao egresso do sistema penitenciário.

Os dados identificam que 06 membros representantes de instituições, exercem a função de gestores (02 Diretores, 01 Gerente, 01 Gestor institucional e 02 Presidentes). Cargo com grandes responsabilidades nos processos e tomadas de decisões, no que diz respeito ao planejamento, avaliação e monitoramento dos resultados, de projetos destinados a assistência de internos e egressos e do sistema penitenciário.

\subsubsection{5.}

\section{Área de atuação}

Tabela 3- Área de atuação

\begin{tabular}{||l|l|l||}
\hline ÁREA DE ATUAÇÃ̃ & ABS & $(\%)$ \\
\hline Assistência Social & 02 & 16,6 \\
\hline Apoio religioso e jurídico & 02 & 16,6 \\
\hline Direitos Humanos & 02 & 16,6 \\
\hline Educação & 01 & 8,4 \\
\hline Psicossocial & 02 & 16,6 \\
\hline Sócio Jurídico & 01 & 8,4 \\
\hline Qualificação profissional & 02 & 16,6 \\
\hline Total & $\mathbf{1 2}$ & $\mathbf{1 0 0}$ \\
\hline
\end{tabular}

Fonte: Pesquisa realizada no mês de junho de 2015, com membros participantes da Rede de apoio ao egresso do sistema penitenciário.

\footnotetext{
${ }^{36}$ Números absolutos.
} 
Observamos na tabela acima, que a RAESP, atua em diferentes áreas, de forma equilibrada, a abranger todas as áreas possíveis e de extrema importância na inserção social dos pré egressos e egressos do Sistema. A área de Educação, ainda precisa de reforço, visto que é de fundamental importância para que a transformação social acontecesse.

Para a questão abaixo, apresentamos várias alternativas, que poderiam ter mais de uma reposta.

Os principais serviços ofertados são:

- Capacitação para o mercado de trabalho (11)

- Encaminhamento para mercado de trabalho (5) e Inserção na geração de renda e trabalho formal (1)

- Atendimento Social (4)

- Atendimento educacional ( 4)

- Orientação e atendimento jurídico (4)

- Atendimento Psicológico (3)

- Regularização de documentação civil (3)

- Apoio nas áreas de saúde (2)

- Auxilio passagem (1)

- Auxilio alimentação (1) e Cesta básica (1)

- Progressão do regime, pedido de liberdade, comutação (1)

- Transferências de internos, indultos, visitas à família, revisão de crime, acompanhamento do processo, defesa do julgado. (1)

- Aconselhamento as pessoas que se encontram em situações vulneráveis emocionalmente e espiritualmente. (1)

Verificamos que das 12 instituições entrevistadas, 11 ofertam capacitação para o mercado de trabalho. Visto que a inserção no mercado de trabalho, na maioria das vezes, é responsabilidade das empresas, do cenário externo, que está aquém da atuação da RAESP, que tem como um dos seus objetivos sensibilizar o empresariado.

A maior demanda apresentada pelos internos e egressos é a inserção no mercado de trabalho, porém com a capacitação profissional, aumentam as chances 
daqueles que nunca tiveram experienciais de trabalho anterior ao cárcere, serem inseridos.

\subsubsection{6.}

Tempo de participação na RAESP

\section{Gráfico 2 - Tempo de participação na RAESP}

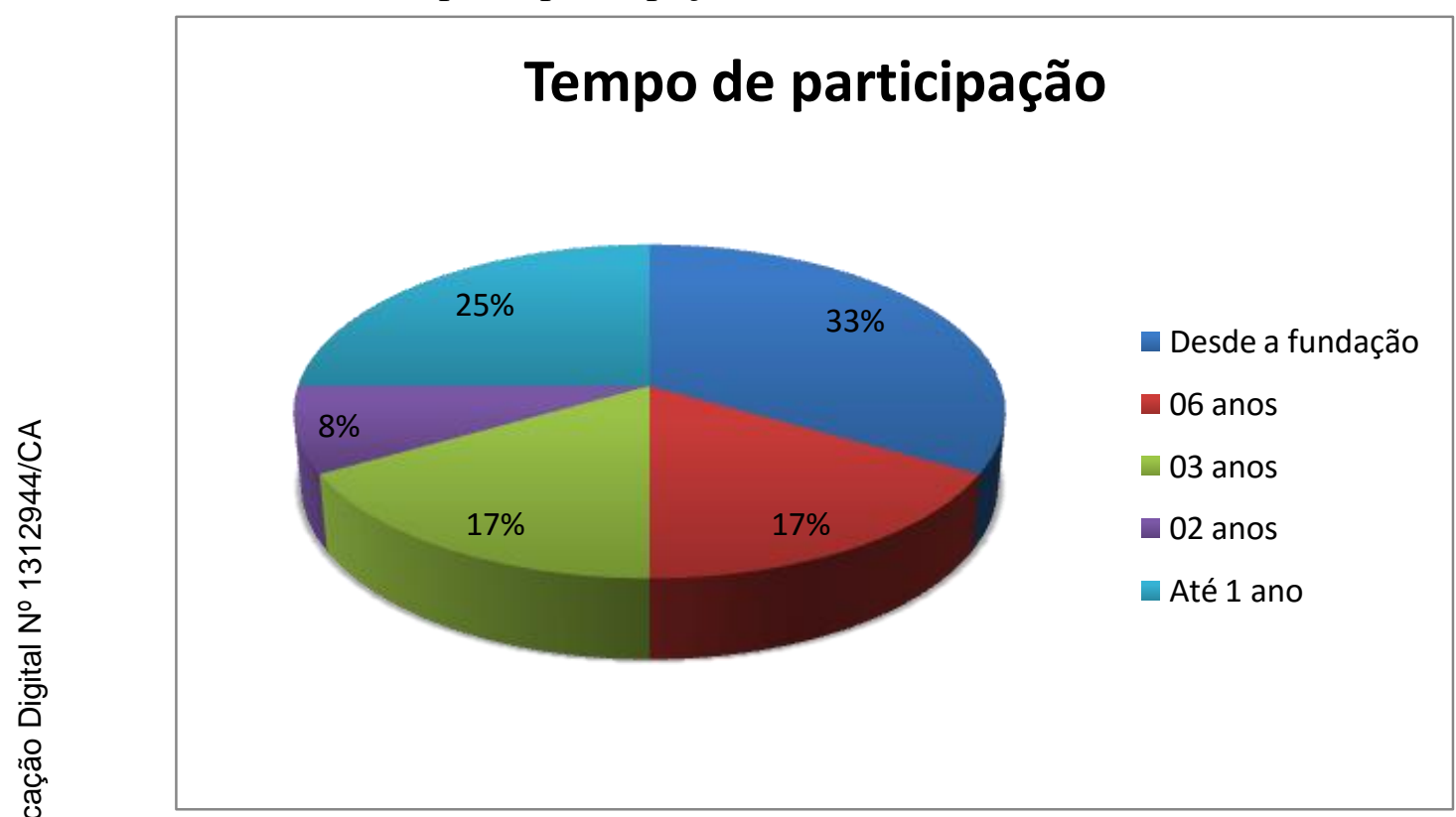

Fonte: Pesquisa realizada no mês de junho de 2015, com membros participantes da Rede de apoio ao egresso do sistema penitenciário.

A RAESP nesses 9 anos de existência, vem ampliando suas ações e também a inserção de mais membros. 33\% (04) dos entrevistados estão desde a fundação da Rede, em maio de 2006.

Desde sua criação até os dias de hoje, passaram pela rede algumas instituições localizadas no Estado do Rio de Janeiro e que atuavam com o mesmo público alvo. Passando por algumas transformações, hoje conta com 12 instituições, 10 membros individuais e seus parceiros. Houve evasões de algumas instituições que deixaram de participar da rede, pois seus objetivos não eram compatíveis com os demais membros e com o objetivo principal da RAESP.

A RAESP está em constante expansão, 25\% (03) dos entrevistados, participam há menos de 1 ano da Rede. O que nos mostra esse quadro, em termos 
de investimentos no reforço ao trabalho com egressos, é a forma de instituições se unirem e ampliação de espaços de atenção a esse público.

\subsubsection{7.}

\section{Público Alvo}

As instituições que compõem a Rede, assistiram numa dimensão interinstitucional, aproximadamente 23.523 pessoas - homens e mulheres (somatório dos atendidos por todas as instituições em 2014).

Gráfico 3- Público Alvo

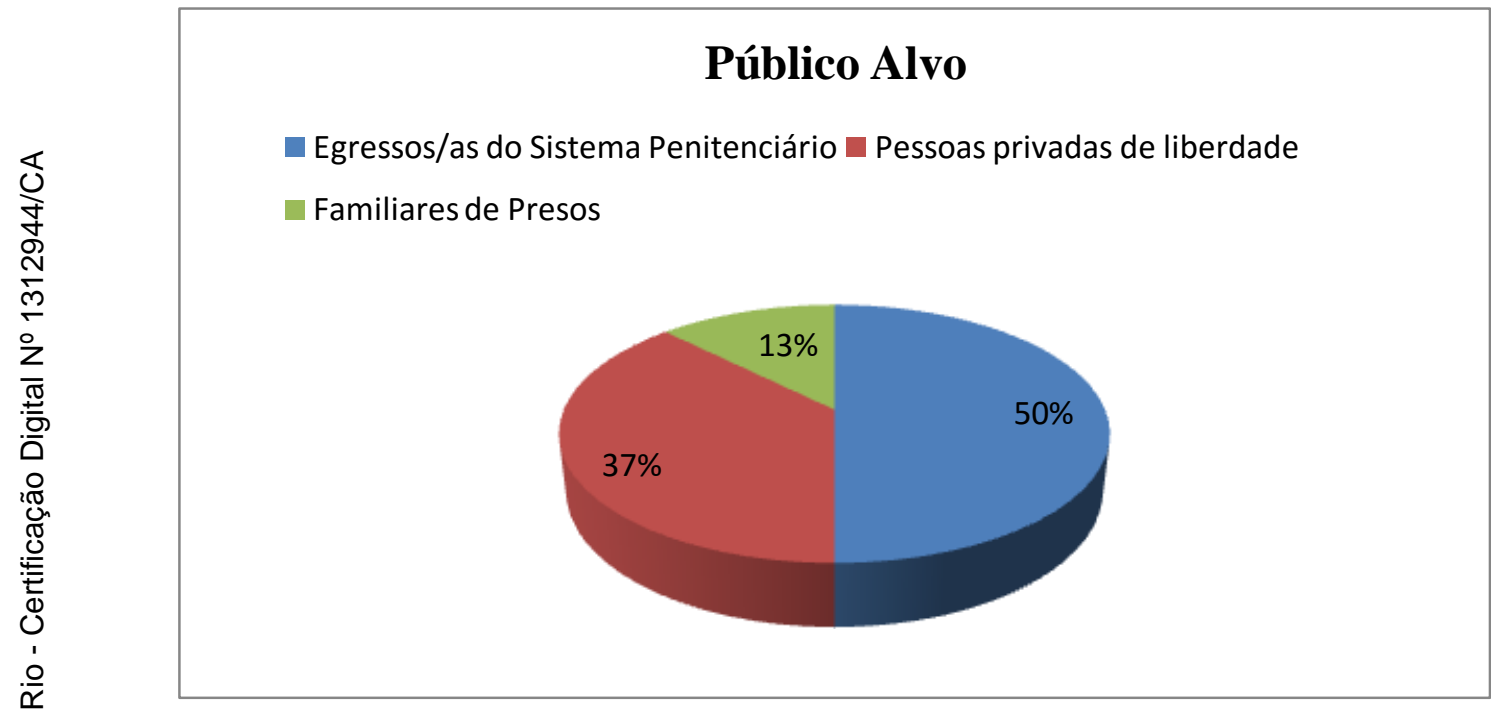

Fonte: Pesquisa realizada no mês de junho de 2015, com membros participantes da Rede de apoio ao egresso do sistema penitenciário.

Esses dados identificam que 50\% dos usuários atendidos pela Rede, são os egressos e egressas do sistema penitenciário, seguido de $38 \%$ de internos e internas, em cumprimento de pena e $13 \%$ de familiares de pessoas presas.

Segundo o levantamento feito pelo DEPEN (Junho/2014), 57,5\% dos presos brasileiros se declaram solteiros, $28,8 \%$, em união estável e 10,2\% casados. O encarceramento trás consequências, não só para os presos, mas também a seus familiares. Uma pesquisa realizada pela ${ }^{37}$ Universidade de Princeton, sobre o

$37 \mathrm{O}$ estudo foi realizado pela Bendheim-Thoman Center for Research on Child Wellbeing, da Universidade de Princeton. Os resultados da pesquisa estão disponíveis no endereço: http://www.fragilefamilies.princeton.edu/briefs/ResearchBrief42.pdf 
impacto da prisão na vida de famílias, constatou que entre outras consequências, crianças que têm o pai privado de liberdade têm $44 \%$ mais chances de apresentar comportamento agressivo.

\subsubsection{8.}

\section{Origem do Público atendido}

As demandas espontâneas representam $63 \%$, de origem do público atendido pela RAESP. Quando os usuários procuram as instituições que compõe a Rede, seja por conta própria ou indicado por ex-participantes, e/ou familiares.

Gráfico 4- Origem do Público

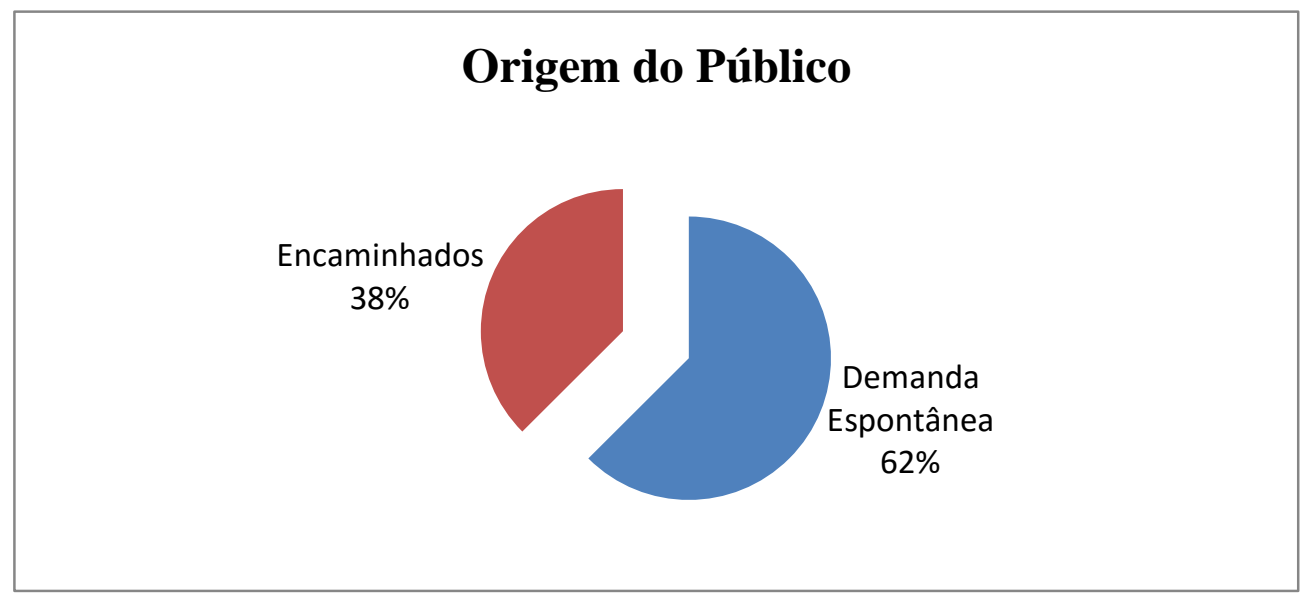

Fonte: Pesquisa realizada no mês de junho de 2015, com membros participantes da Rede de apoio ao egresso do sistema penitenciário.

Das Instituições que mais encaminham para a RAESP, entre elas estão:

Secretaria de Estado e Administração Penitenciária do Rio de Janeiro - SEAP (6)

Tribunal de Justiça (2) / Central de Penas e medidas alternativas e Vara de

Execuções Penais - VEP

Instituições Católicas (2)

Conselho Tutelar (1)

Centro de Referência de Assistência Social - CRAS (1)

Dessas instituições, $90 \%$ são as públicas, que mais encaminham os usuários para atendimento na Rede.

E as principais demandas viabilizadas/encaminhadas e atendidas, são: 
- Encaminhamento para mercado de trabalho (6)

- Curso de capacitação profissional (5)

- Atendimento Jurídico (3)

- Documentação (3)

- Resgate do relacionamento familiar (1)

- Doações de materiais de higiene pessoal (1)

- Atendimento de Saúde (1)

- Pecúlio (1)

- Encaminhamento para CRAS (1)

- Encaminhamento para rede cidadã (1)

- Reconhecimento de sua dignidade (1)

OBS: (Nessa questão apresentamos várias alternativas, que poderiam ter mais de uma reposta).

\subsection{2.}

\section{Perfil do Público Alvo}

Neste item, apresentaremos o perfil do público, atendido pela Rede, considerando as seguintes variáveis: sexo do publico dominante; faixa etária; escolaridade; Tempo na prisão; delitos mais frequentes e principais demandas apresentadas. 


\subsubsection{1.}

\section{Público dominante}

Gráfico 5- Sexo do Público predominante

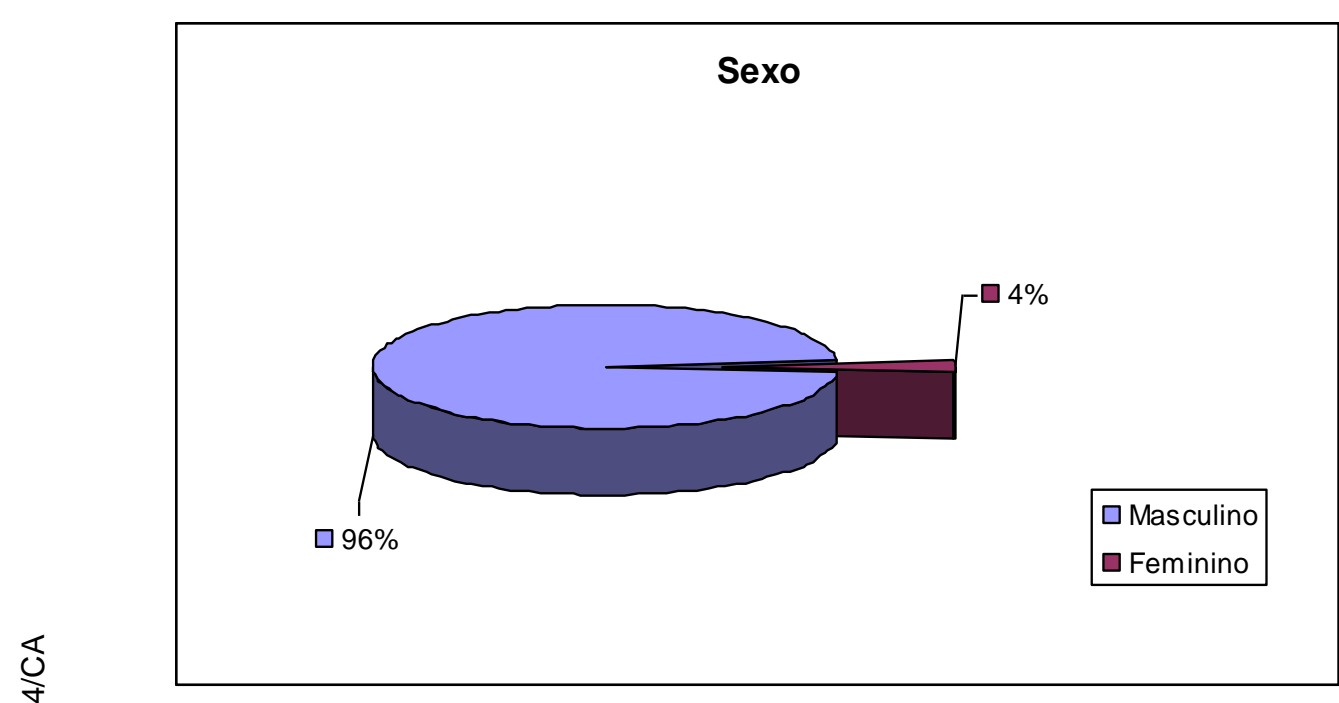

Fonte: Pesquisa realizada no mês de junho de 2015, com membros participantes da Rede de apoio ao egresso do sistema penitenciário.

Nesta pesquisa, a presença do sexo masculino é de mais de $90 \%$, nas instituições participantes, sendo $4 \%$ dos atendidos do sexo feminino. Em quatro das instituições entrevistadas, a predominância é de ambos os sexos.

\subsubsection{2.}

\section{Faixa etária}

Sobre a idade do público atendido pela rede, a pesquisa constatou o seguinte quadro: 19\% (07) têm idade entre 18 a 24 anos; 44\% (16) entre 25 a 40 anos; 14\% (05) entre 41 a 50 anos, e os demais se encontram na faixa etária entre 51 a 60 anos, $16 \%$ (06). Conferir gráfico 6 : 
Gráfico 6 - Faixa etária

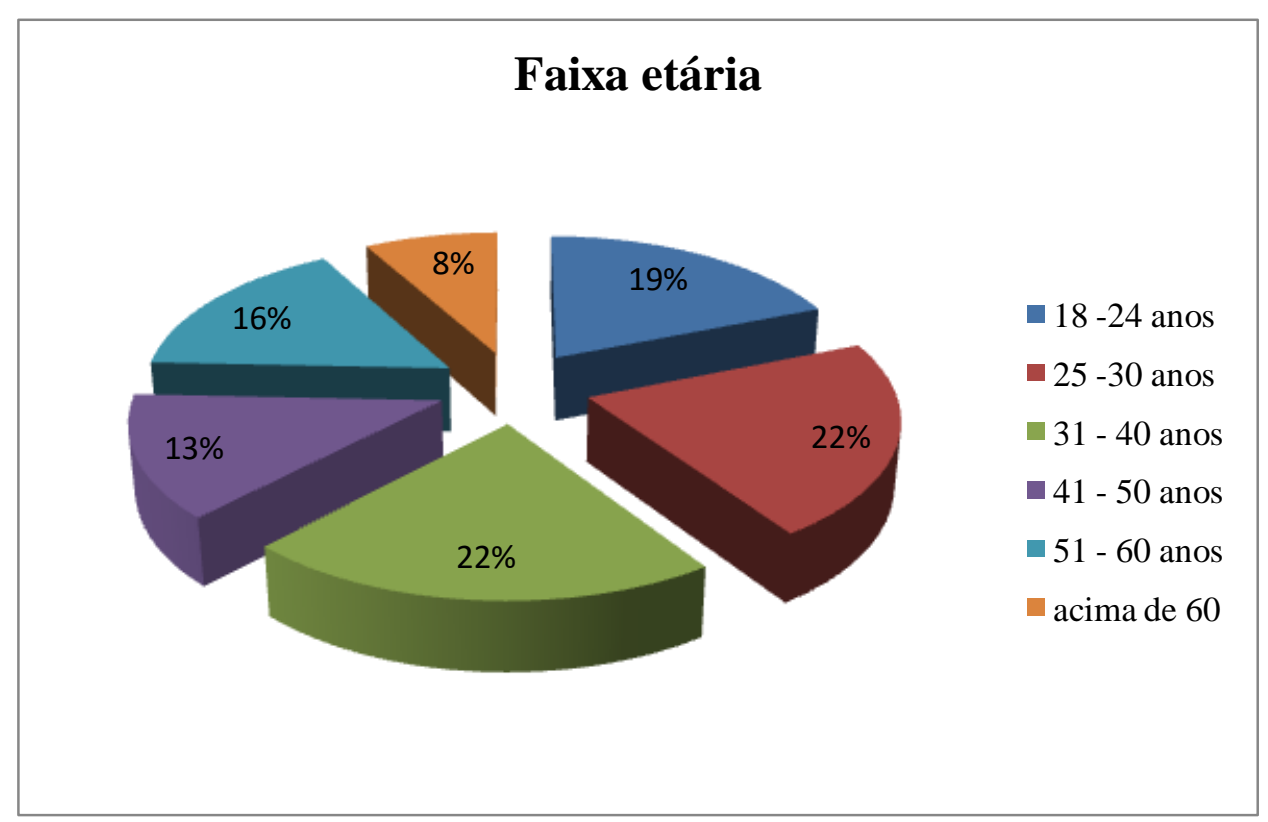

Fonte: Pesquisa realizada no mês de junho de 2015, com membros participantes da Rede de apoio ao egresso do sistema penitenciário.

Observa-se que os resultados mostram um número expressivo de egressos (44\%) com idade variando entre 25 a 40 anos. Segundo dados do IINFOPEN, $31 \%$ dos presos tem faixa entre 18 a 25 anos (Brasil, 2014). Sendo assim, a RAESP presta assistência, logo após a saída da prisão, dessas pessoas.

\subsubsection{3.}

\section{Escolaridade}

Quanto à escolaridade, verifica-se, através dos dados coletados, que $45 \%$ (10) têm o ensino fundamental incompleto; $15 \%$ (04) têm o ensino fundamental completo; $15 \%$ (04) possuem o ensino médio incompleto; 12,5\% (03) têm o ensino médio completo; e 12,5\% (03) possuem o ensino superior incompleto. De acordo com a tabela 4 . 
Tabela 4- Escolaridade

\begin{tabular}{||l|l|l||}
\hline ESCOLARIDADE & ABS & $(\boldsymbol{\%})$ \\
\hline Ensino fundamental incompleto & 10 & 41,7 \\
\hline Ensino fundamental completo & 4 & 16,7 \\
\hline Ensino médio incompleto & 4 & 16,7 \\
\hline Ensino médio completo & 3 & 12,5 \\
\hline Ensino superior incompleto & 3 & 12,5 \\
\hline Total & $\mathbf{2 4}$ & $\mathbf{1 0 0}$ \\
\hline
\end{tabular}

Fonte: Pesquisa realizada no mês de junho de 2015, com membros participantes da Rede de apoio ao egresso do sistema penitenciário.

(Nessa questão apresentamos várias alternativas, que poderiam ter mais de uma reposta)

Os dados sobre a escolaridade identificam uma expressividade (45\%) para o ensino fundamental incompleto. A escola pode representar um referencial positivo na vida das pessoas, sendo a permanência nesta pelo maior tempo possível, um mecanismo de contribuição para a redução da criminalidade. Sendo, inclusive, um direito previsto na legislação.

\subsubsection{4. \\ Média de tempo no sistema Penitenciário}

Tabela 5 - Tempo de reclusão

\begin{tabular}{||l|l|l||}
\hline TEMPO DE PRISÃO & ABS & $\mathbf{( \% )}$ \\
\hline Menos de 1 ano & 1 & 8,3 \\
\hline De 1 a 3 anos & 1 & 8,3 \\
\hline De 4 a 6 anos & 2 & 16,7 \\
\hline De 7 a 10 anos & 3 & 25 \\
\hline De 11 a 15 anos & 2 & 16,7 \\
\hline Não responderam & 3 & 25 \\
\hline Total & $\mathbf{1 2}$ & $\mathbf{1 0 0}$ \\
\hline
\end{tabular}

Fonte: Pesquisa realizada no mês de junho de 2015, com membros participantes da Rede de apoio ao egresso do sistema penitenciário.

De acordo, com os dados do INFOPEN/2014, 25,7\% dos presos brasileiros, cumprem penas, de mais de 4 anos até 8 anos de reclusão. Seguido de 23\%, daqueles que cumprem penas, de mais de 8 anos até 15 anos de detenção. 


\subsubsection{5. \\ Motivo de Inserção no sistema prisional}

Gráfico 7- Artigos/Delitos

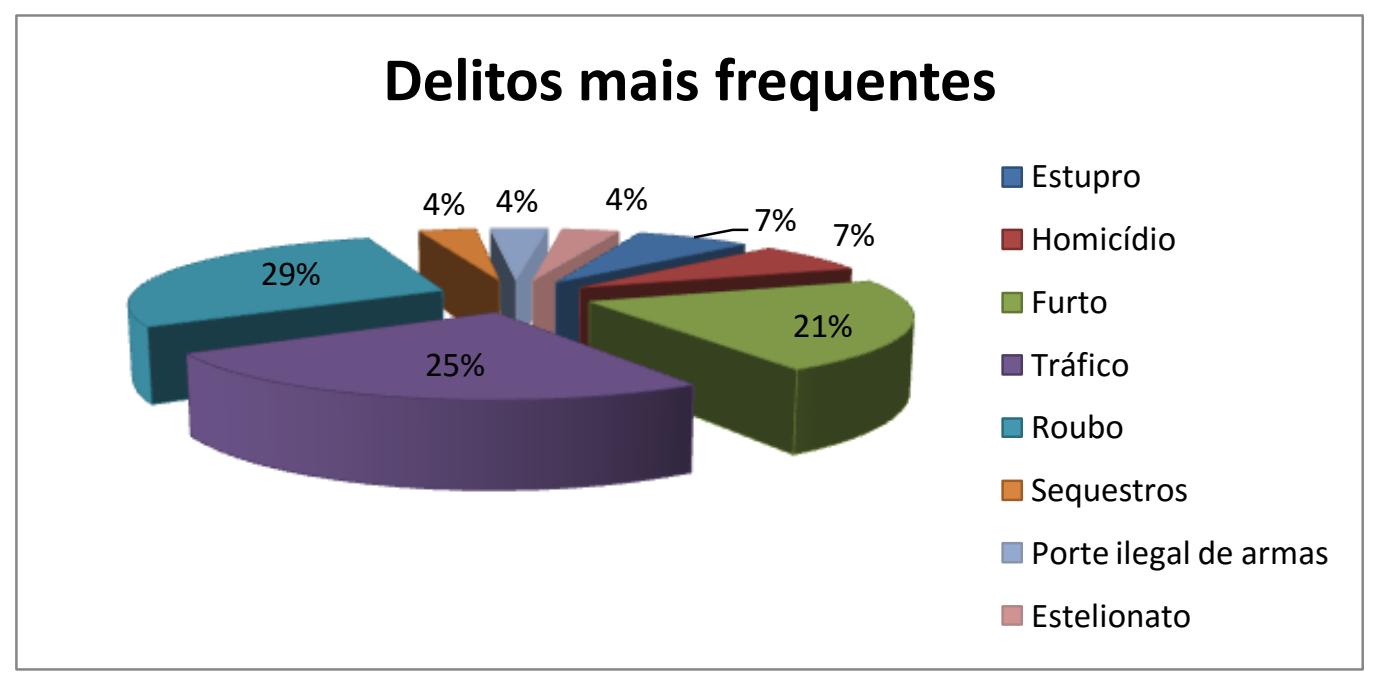

Fonte: Pesquisa realizada no mês de junho de 2015, com membros participantes da Rede de apoio ao egresso do sistema penitenciário.

Ainda de acordo com o relatório do DEPEN/junho 2014, os delitos que mais aparecem como responsável pelas prisões são os crimes contra o patrimônio: roubo, furto, latrocínio... (97.206); os de legislações específicas - de Drogas: Tráfico, associação ao tráfico e tráfico internacional (66.313); seguido dos crimes contra a pessoa: homicídios, lesão corporal, violência doméstica... (39.605). 


\subsubsection{6.}

\section{Principais demandas dos atendidos}

Tabela 6- Principais demandas

\begin{tabular}{||l|l|l||}
\hline DEMANDAS & ABS & $\mathbf{( \% )}$ \\
\hline Trabalho & 10 & 25,6 \\
\hline Documentação & 8 & 20,5 \\
\hline Capacitação & 5 & 12,8 \\
\hline Atendimento Jurídico & 5 & 12,8 \\
\hline Atendimento Psicológico & 4 & 10,3 \\
\hline Aumento de Escolaridade & 3 & 7,7 \\
\hline Atendimento de Saúde & 3 & 7,7 \\
\hline Cesta básica & 1 & 2,6 \\
\hline Total & $\mathbf{3 9}$ & $\mathbf{1 0 0}$ \\
\hline
\end{tabular}

Fonte: Pesquisa realizada no mês de junho de 2015, com membros participantes da Rede de apoio ao egresso do sistema penitenciário.

(Nessa questão apresentamos várias alternativas, que poderiam ter mais de uma reposta)

Outras demandas Principais atendidas, pela Rede: Contato de família dos internos, resgate de pecúlio, apoio nas atividades administrativas (realização de matriculas), albergagem e internação para dependência química.

A principal demanda dos usuários é por trabalho. O trabalho é um dos fatores mais importantes no processo de inserção social. Seja no trabalho formal ou autônomo. Onde se justifica a afirmação de Forti (2005):

"O trabalho é atividade vital para a existência humana, atividade que a constitui e a caracteriza, fonte de satisfação das necessidades do ser humano e a sua possibilidade histórica" (Forti, 2005, p. 1). Em outras palavras, o trabalho na vida humana tem uma posição central, pois a partir dele o homem pode prover a sua sobrevivência e a de sua família.

\subsection{3.}

\section{Avaliação da Rede}

Ao realizar a pesquisa com os membros da RAESP, consideramos de suma importância conhecer a avaliação dos participantes sobre o entendimento de Rede. 
Este item será analisado sob o enfoque da análise qualitativa, pois as respostas abrangem o universo dos significados, traduzidos através da linguagem.

As questões, que envolvem a avaliação sobre a RAESP e parcerias, foram extraídas de depoimentos obtidos durante a entrevista, ou seja, trata-se de registros de algumas narrativas dos entrevistados sobre a sua participação. Apresentaremos 6 respostas aleatoriamente, dos entrevistados, para cada pergunta (no total 7 perguntas elaboradas).

Quadro 1 - O que entende por rede?

\begin{tabular}{|c|c|}
\hline $\begin{array}{l}\text { Conjunto de parceiros atuando em } \\
\text { conexão em benefício de algo ou de um } \\
\text { grupo de pessoas. }\end{array}$ & $\begin{array}{l}\text { Articulação entre diversas instituições, } \\
\text { que realizam atividades complementares } \\
\text { umas às outras, potencializando melhor } \\
\text { resultados para todas. Sobretudo, uma } \\
\text { nova forma de enfrentar as consequências } \\
\text { das desigualdades sociais, que são } \\
\text { múltiplas e exigem diferentes atores em } \\
\text { articulação. }\end{array}$ \\
\hline $\begin{array}{l}\text { Rede é uma construção cotidiana que } \\
\text { realizamos entrelaçando diversas metas e } \\
\text { formas de fazer para alcançarmos um } \\
\text { objetivo comum. }\end{array}$ & $\begin{array}{l}\dot{E} \text { uma estrutura composta por pessoas } \\
\text { ou organizações governamentais ou não, } \\
\text { conectadas por um ou vários tipos de } \\
\text { relações, que compartilham valores e } \\
\text { objetivos comuns. }\end{array}$ \\
\hline $\begin{array}{l}\text { Instituições parceiras e integradas que } \\
\text { façam atendimento complementares a } \\
\text { usuários com o mesmo perfil. }\end{array}$ & $\begin{array}{l}\text { É uma forma de integrar as atividades } \\
\text { desenvolvidas pelos diversos parceiros, } \\
\text { de acordo com as demandas apresentadas } \\
\text { pelos egressos do Sistema Penitenciário, } \\
\text { bem como daqueles que ainda estão no } \\
\text { cárcere, em virtude de reus } \\
\text { desdobramentos, por ocasiãor da } \\
\text { progressão de regime. }\end{array}$ \\
\hline
\end{tabular}

Fonte: Pesquisa realizada no mês de junho de 2015, com membros participantes da Rede de apoio ao egresso do sistema penitenciário.

Ao analisar as respostas, identificamos que o conceito de Rede, apresentado pelos membros da RAESP, indica que a Rede é composta por instituições parceiras, que desenvolvam atividades integradas e com objetivos comuns. Uma estrutura social conectada por vários tipos de relações. Que podem formam sistemas organizacionais de forma democrática e participativa. 
Percebemos o comprometimento dos entrevistados, com relação aos resultados e metas obtidos, em favor do mesmo público alvo, com o propósito de enfrentamento das desigualdades sociais.

Quadro 2 - Em sua opinião, qual a relação das Políticas Públicas com as Redes Sociais?

As Redes Sociais possibilitam o contato com outras instituições que estão inseridas em diversos territórios. Traz a particularidade daquela localidade. Possibilitando identificar onde há necessidade de uma atuação mais presente das Políticas Públicas, assim podendo participar na formulação de Políticas.

Incipiente. $O$ poder público não responde a contento as demandas das redes sociais e não apoia as iniciativas exitosas.
As redes sociais podem ser instrumentos valiosos na consecução de políticas públicas, todavia o tipo especial de políticas públicas ao interno requer outras considerações no que tange ao contato entre pessoas.
Quando não é extremamente burocrático, existe a falta de reconhecimento das Redes Sociais por parte das Políticas Públicas.
A relação é a da prática. As Redes Sociais fazem parte dos atores e operadores do sistema, para que as políticas públicas possam ser colocadas em prática no Brasil.
Algumas políticas públicas nasceram das demandas por reconhecimento das causas trabalhadas pelas redes sociais. Aqui, eu não estou falando de milagres, mas, de um forte empenho das redes sociais em suas reivindicações junto ao poder público.

Certamente, há demandas sociais em que as politicas tendem a desconhecer ou mesmo manipular a ação das redes sociais, constituindo uma relação quase que contraditória.

Fonte: Pesquisa realizada no mês de junho de 2015, com membros participantes da Rede de apoio ao egresso do sistema penitenciário.

No que se refere às Políticas Públicas e a relação com as Redes Sociais, os entrevistados colocam que essa relação acontece, através do contato entre pessoas e instituições, localizadas em diferentes territórios.

Com demandas sociais que representam as Redes Sociais, como instrumentos valiosos na formulação e consecução de Políticas Públicas. Essa relação torna possível uma mudança de mentalidade a partir da tomada de consciência dos problemas que afligem as comunidades. 
Porém as Políticas não apoiam as iniciativas exitosas e ainda existe falta de reconhecimento das Redes Sociais, por parte dessas Políticas. Políticas essas que são ausentes e fragilizadas no atendimento das especificidades do público beneficiário.

Quadro 3 - Qual é o papel da Rede de Apoio ao Egresso, na vida dos usuários e para a Sociedade Brasileira?

\begin{tabular}{|c|c|}
\hline $\begin{array}{l}\text { Primordial para dar visibilidade aos } \\
\text { invisiveis e lutar por uma sociedade mais } \\
\text { justa. }\end{array}$ & $\begin{array}{l}\text { É um papel de alcance de Cidadania e } \\
\text { responsabilidade social. }\end{array}$ \\
\hline $\begin{array}{l}\text { Na vida dos usuários é de fundamental } \\
\text { importância, já que a necessidade de } \\
\text { atendimento não é suprida pelas em } \\
\text { instituições públicas que deveriam } \\
\text { desenvolver o trabalho. } \\
\text { o trabalho desenvolvido pela RAESP tem } \\
\text { um papel fundamental para a sociedade, } \\
\text { visto que busca integrar estas pessoas a } \\
\text { sociedade e promove a reflexão sobre suas } \\
\text { condições de vida. }\end{array}$ & $\begin{array}{l}\text { A rede aproxima ativistas e usuários e } \\
\text { contribui para a solução de impasses } \\
\text { acerca de políticas públicas não apenas } \\
\text { dos egressos e das egressas, mas } \\
\text { também de quem ainda está em } \\
\text { cumprimento de pena. } \\
\text { A sociedade se beneficia, na medida em } \\
\text { que as ações empreendidas colaboram } \\
\text { para a chamada ressocialização das } \\
\text { pessoas que passaram pelo cárcere. }\end{array}$ \\
\hline $\begin{array}{l}\text { A possibilidade de garantia dos direitos } \\
\text { sociais, reflexão e a oportunidade dos } \\
\text { usuários em fazer escolhas. }\end{array}$ & $\begin{array}{l}\text { A Rede de apoio ao egresso na vida dos } \\
\text { usuários possibilita acesso aos serviços } \\
\text { a um segmento que sofre com a } \\
\text { discriminação quando busca } \\
\text { atendimento e o direito a participação. } \\
\text { A RAESP possibilita para a sociedade a } \\
\text { quebra de paradigmas sobre os egressos } \\
\text { e viabiliza a redução na reincidência. }\end{array}$ \\
\hline
\end{tabular}

Fonte: Pesquisa realizada no mês de junho de 2015, com membros participantes da Rede de apoio ao egresso do sistema penitenciário.

Avaliamos, que o Papel da Rede na vida dos Egressos e para a Sociedade, se faz necessário no acesso aos serviços, na garantia dos direitos sociais e no alcance de cidadania, na trajetória de vida desses usuários.

A Rede de Apoio desempenha um papel diante da sociedade de responsabilidade social, dando visibilidade aos invisíveis, a este segmento que sofre com a discriminação. E contribuindo com a tentativa de redução da reincidência criminal Brasileira. Vem cumprindo o papel de mediadora, entre essas duas instâncias, objetivando a inserção dos egressos na sociedade. 
Conforme Madeira (2004), “... A constituição das redes de egressos representa um papel importante para suas relações de pertencimento, verificandose a constituição de atores que, apesar de estigmatizados, veem-se com certa voz e força política".

Quadro 4 - Qual a importância da RAESP na condição de rede a egressos?

Dar suporte aos egressos em sua relação com os diversos setores da sociedade, como Governo, as empresas privadas, as ONGs, assim como em seus relacionamentos interpessoais.

Promove a integração das instituições de atendimento e dando maior visibilidade à questão e ao trabalho desenvolvido.

A RAESP é a única Rede que busca a inserção do egresso do sistema penal à sociedade com dignidade humana, através da capacitação profissional e cidadania.

A Rede, além de socializar informações, levanta assuntos para diálogo entre os envolvidos na Rede, e suscita ações visando melhorar a condição do preso e da presa, junto à SEAP e instituições ligadas ao sistema, como exemplo a Fundação Santa Cabrini.
Articula, mobiliza e provoca o Poder Público; demonstrando que com planejamento e profissionalismo é possível alcançar resultados positivos.
É relevante na medida em que de certo modo A RAESP é a única Rede que busca a inserção do egresso do sistema penal à sociedade.
A importância é mostrar o valor das ações em complementaridade. É quase impossível a uma instituição assumir sozinha a complexidade das consequências que a prisão imputa aos egressos deixando-os sem a formação adequada para o reingresso na sociedade, o que poderia ser feito em simples ações como não saírem da prisão sem documentos, sem escolaridade requerida no mercado. As instituições da RAESP, em pouco tempo, já estão levando egressos a ingressarem na universidade. São casos isolados. Poderiam ser aumentados se o Sistema prisional também funcionasse em moldes de uma rede de apoio, com foco em objetivos de reinserção social.

Fonte: Pesquisa realizada no mês de junho de 2015, com membros participantes da Rede de apoio ao egresso do sistema penitenciário.

Quando perguntado aos entrevistados sobre a importância da RAESP na condição de rede a egresso, podemos constatar o seguinte:

No que diz respeito ao suporte dados aos usuários, a RAESP é a única Rede que busca a inserção do egresso do sistema penal à sociedade, no Rio de Janeiro. Vem buscando sensibilizar o empresariado na importância de integrar os egressos no mercado de trabalho. Beneficiando diretamente seus familiares e a sociedade de modo geral. 
A importância é mostrar o valor das ações em complementaridade. Buscando socializar as informações entre seus membros, através do planejamento e do profissionalismo, tornando possível alcançar resultados positivos.

Quadro 5 - Qual o objetivo da instituição em participar da Rede?

\begin{tabular}{|c|c|}
\hline $\begin{array}{l}\text { Contribuir de forma direta na reconstrução } \\
\text { social e fortalecimento de vínculos dos } \\
\text { menos favorecidos em conjunto com as } \\
\text { redes sociais. }\end{array}$ & $\begin{array}{l}\text { Contribuir para a realização de } \\
\text { propostas que o Instituto Amendoeiras } \\
\text { não pode desenvolver sozinho, e } \\
\text { contribuir para a realização de outras } \\
\text { propostas das entidades parceiras que } \\
\text { ampliam os ganhos de nossos usuários. }\end{array}$ \\
\hline $\begin{array}{l}\text { Garantir as parcerias, os encaminhamentos } \\
e \text { a efetivação destes, prevalecendo os } \\
\text { direitos dos usuários. }\end{array}$ & $\begin{array}{l}\text { Divulgar, ampliar e fortalecer o } \\
\text { trabalho que realizamos com união a } \\
\text { instituições elou pessoas afins. }\end{array}$ \\
\hline $\begin{array}{l}\text { Ampliar sua atuação no seu foco de } \\
\text { atuação, ampliar seus contatos com demais } \\
\text { instituiçóes governamentais e nâso } \\
\text { governamentais, partilhar experiências na } \\
\text { promoção de resultados junto aos internos / } \\
\text { egressos como forma de efeito } \\
\text { multiplicador de boas práticas; } \\
\text { disponibilizar aos demais parceiros } \\
\text { conhecimentos, assessorias, resultados, } \\
\text { pesquisas, voltadas para resultados com } \\
\text { internos / egressos. }\end{array}$ & $\begin{array}{l}\text { A participação na RAESP possibilita a } \\
\text { articulação com as instituiçóes que } \\
\text { atendem os egressos e conhecer o } \\
\text { debate atual sobre essa demanda. }\end{array}$ \\
\hline
\end{tabular}

Fonte: Pesquisa realizada no mês de junho de 2015, com membros participantes da Rede de apoio ao egresso do sistema penitenciário.

Os objetivos das instituições em fazerem parte da RAESP, em sua maioria são de ampliação e fortalecimento de suas ações, contribuindo para a realização de outras propostas das entidades parceiras, que ampliam os ganhos dos usuários com o atendimento e resoluções das demandas apresentadas.

A participação na RAESP possibilita a articulação com as instituições que atendem os egressos e conhecimento do debate atual sobre essa demanda. Estudar casos para o planejamento das intervenções, sendo dirigidas a prevalecer os direitos dos usuários. 
Quadro 6 - Considera que a RAESP alcança seus objetivos? De que forma/Por quê?

\begin{tabular}{|c|c|}
\hline $\begin{array}{l}\text { Em parte sim. Devido aos esforços } \\
\text { coletivos de seus membros. }\end{array}$ & $\begin{array}{l}\text { Um dos objetivos é desenvolver um } \\
\text { debate entre os parceiros com vistas à } \\
\text { apresentação de propostas para os } \\
\text { formuladores de políticas, seja a nível } \\
\text { estadual ou federal, considerando que } \\
\text { os trabalhos realizados pelos parceiros, } \\
\text { dialogam diretamente com as demandas } \\
\text { dos internos legressos do Sistema } \\
\text { Penitenciário. }\end{array}$ \\
\hline $\begin{array}{l}\text { Estamos, ainda engatinhando, mas já } \\
\text { podemos comemorar o reconhecimento nos } \\
\text { fóruns que debatem as questões } \\
\text { relacionadas ao Sistema Prisional. O } \\
\text { objetivo principal está longe de ser } \\
\text { alcançado pois algumas açôes dependem, } \\
\text { exclusivamente, dos poderes executivo e } \\
\text { judiciário; porém continuamos alertando, } \\
\text { provocando e cobrando resultados. }\end{array}$ & $\begin{array}{l}\text { Sim. Na integração e conhecimento das } \\
\text { ações de cada grupo, na reintegração e } \\
\text { ressocialização do egresso do sistema } \\
\text { penal. }\end{array}$ \\
\hline $\begin{array}{l}\text { Em um universo de negação constante dos } \\
\text { direitos, num contexto em que a própria } \\
\text { sociedade reclama pela redução dos } \\
\text { direitos oferecidos às pessoas privadas de } \\
\text { liberdade, a própria atuação já é um } \\
\text { alcance de objetivos, mas há mais: a } \\
\text { RAESP aproxima ativistas e usuários e } \\
\text { coloca os demandantes em contato com } \\
\text { aqueles que podem atuar para lhes atender. }\end{array}$ & $\begin{array}{l}\text { Sim, diante da sua natureza dessa } \\
\text { instituição de caráter voluntário de seus } \\
\text { membros, sem sede e sem recursos, está } \\
\text { conseguindo se firmar e tornar-se } \\
\text { conhecida nacionalmente como uma } \\
\text { associação que luta pela reinserção da } \\
\text { pessoa egressa no mundo livre, } \\
\text { buscando ações que ampliem a rede e } \\
\text { divulgue a causa. Porém há muito que } \\
\text { caminharmos e até na sua legalização } \\
\text { enquanto instituição formal. }\end{array}$ \\
\hline
\end{tabular}

Fonte: Pesquisa realizada no mês de junho de 2015, com membros participantes da Rede de apoio ao egresso do sistema penitenciário.

Observamos nas respostas acima, a unanimidade do alcance de resultados pela RAESP, mas ainda precisasse de muito mais, em relação à garantia de direito do segmento atendido pela Rede, frente à sociedade e ao Poder Público.

A RAESP tem alcançando seus resultados através também de parcerias com outras instituições, que não fazem parte da Rede. Porém, trabalham coletivamente na divulgação da Rede, na inserção social dos egressos/as, do sistema. Assim formando uma rede cada dia mais forte e reconhecida. E na perspectiva de tornar o cumprimento da pena de prisão mais humana. 
Quadro 7 - Quais os principais resultados da RAESP?

A luta pelo direito à educação, ao trabalho e à saúde. Por exemplo, no direito à educação acolhendo as denúncias dos presos que não conseguem se matricular nas faculdades, apesar de terem cumprido todas etapas de acesso exigidas pelo $M E C$, levando esse tema as várias instâncias do judiciário.

No direito ao trabalho, ampliando parcerias com empregadores como a CEDAE, preparando os egressos para inserção no mercado de trabalho através do Banco da Providência.

Atender a enorme contingente de internos, buscando a reinserção social.

Qualificação, trabalho e renda. A RAESP contribui, por meio de um processo qualificado para que os egressos possam desenvolver habilidades e competências para construir um novo projeto de vida, por meio da qualificação em uma profissão, documentação, encaminhamento a oportunidades de emprego.

Acesso a direitos já disponíveis na sociedade: A RAESP representa uma oportunidade para os egressos acessarem direitos que já estão disponíveis na sociedade, mas, que nem sempre são viáveis para eles. Inclusive $o$ direito a ter uma nova identidade, em ser chamado de trabalhador. Direito ao trabalho decente, a uma vida digna, ao lazer.

Do ponto de vista de resultados para a sociedade, a RAESP representa a vivência do paradigma de que "Um novo mundo é possível", demonstrado pelos resultados que são alcançados.

Do ponto de vista da gestão mostra resultados que podem ser fonte de inspiração para a adoção de novas metodologias em se tratando da reinserção de egressos na sociedade.
Reuniões mensais, I Congresso Nacional de Acompanhamentos $e$ Egressos Afins, Seminários, Palestras, Reportagens, garantia de cursos, trabalhos, orientações, encaminhamentos e outros aos egressos penitenciários.

A integração das instituições parceiras.

Manter-se articulada e agregar, cada vez mais, organizações $e$ pessoas comprometidas com a verdadeira inserção do/a egresso/a.

A nível estadual a RAESP-RJ participou da organização do evento I Congresso Nacional de Atenção a pessoa Egressa e afins, idealizado pela Diretora do Patronato Magarinos Torres, acompanhada de outros parceiros: CEDAE-RJ, TJ-RJ, MASAN - Alimentação, Fundação Santa Cabrini, Banco da Providência, entre outras, realizado em outubro/2014, onde através de seminários foram apresentadas propostas nas diversas áreas como: Saúde Física e Mental; Processos Educacionais Serial Profissionalizante; Assistência Social e Civil; Mercado de Trabalho e Políticas Públicas.

Estas propostas foram apresentadas no I Seminário Nacional de Política para pessoa egressa do Sistema Prisional em novembro /2014, realizado em Brasília - DF, pelo Departamento Penitenciário DEPEN - MJ.

Ampliação dos participantes em nossas reuniões após o I Congresso Nacional de Atenção a pessoa Egressa e afins.

Fonte: Pesquisa realizada no mês de junho de 2015, com membros participantes da Rede de apoio ao egresso do sistema penitenciário. 
Mediante os dados apresentados, verificamos que os principais resultados conquistados pela RAESP, além da integração das instituições parceiras. É a luta pelo direito à educação, ao trabalho e à saúde, promovendo e participando de fóruns, seminários, palestras, reuniões e em reportagens/ entrevistas acerca do tema. Para alcançar a efetivação dos direitos, na garantia de acesso a cursos, trabalhos, orientações, encaminhamentos, entre outros, aos egressos penitenciários. Atuando de forma a reduzir a reincidência prisional, através de oportunidades a essas pessoas.

Em meio à grave expressão da questão social, a criminalidade, revela a reincidência como um problema crucial. Às críticas ao sistema carcerário enquanto "escola do crime", soma-se o fato de que programas voltados para a inserção social surtem um efeito muito ilimitado sobre a vida dos detentos. Além disso, tais ações não alcançam os egressos do sistema, que deveriam ser um público primordial de programas dessa natureza.

Os resultados da pesquisa permitiram consolidar dados para responder o pressuposto de que a Rede Socioassistencial no município do Rio de Janeiro, ainda mostra fragilidade. Porém, através do trabalho em Rede, que a RAESP, com o propósito de assegurar e afirmar os direitos sociais do egresso do sistema penitenciário cumpre o papel de mediadora. E vem tentando mudar esse cenário, com todas as limitações e possibilidades que existem.

A pesquisa concluiu que o acesso dos egressos a programas de capacitação para o trabalho deve ser priorizado. O fortalecimento de programas de pleno desenvolvimento humano, que visem à construção do autorrespeito e da autodeterminação, como primeiro passo no exercício da cidadania, pode criar condições para diminuir a reincidência no crime.

Esta pesquisa demonstrou que as políticas públicas para esse segmento de usuários, são frágeis ou inexistentes. Tornando fundamental a permanente busca pela humanização do sistema prisional e o estímulo do apoio ao egresso e de sua inserção ao trabalho.

A RAESP não se propõe a fazer o papel do Estado, mas sim contribuir com os órgãos responsáveis, demonstrando que com planejamento e profissionalismo é possível alcançar resultados positivos. O propósito da RAESP é que as experiências bem sucedidas das Organizações que a compõe, transformem-se em Políticas Públicas. Sempre na perspectiva de ampliação dos mecanismos de 
fortalecimento do egresso do sistema penitenciário para que ele participe de forma ativa do processo de inserção social e passe a ocupar o espaço que lhe é de direito: o de cidadão brasileiro.

\section{2. Estudo de Caso: Um olhar dos (Pré) Egressos em relação à Rede socioassistencial de atendimento}

Complementando os resultados apresentados, foram realizadas entrevistas e aplicação do questionário de pesquisa, com 3 membros individuais da RAESP. Dois internos do regime semiaberto (pré-egressos) e um egresso em Liberdade Condicional. A fim de compreendermos, o papel da rede socioassistencial para o segmento de usuários.

Quadro 8- Perfil dos entrevistados

\begin{tabular}{|l|l|l|l|l|l|l|}
\hline Usuários & Idade & Escolaridade & Profissão & $\begin{array}{l}\text { Tempo de } \\
\text { Reclusão }\end{array}$ & Regime & $\begin{array}{l}\text { Tempo de } \\
\text { participa- } \\
\text { ção na } \\
\text { RAESP }\end{array}$ \\
\hline A & 36 & $\begin{array}{l}\text { Ens. Médio } \\
\text { cursando }\end{array}$ & $\begin{array}{l}\text { Auxiliar de } \\
\text { documentação }\end{array}$ & 17 anos & $\begin{array}{l}\text { Liberdade } \\
\text { Condicional }\end{array}$ & 6 meses \\
\hline B & 45 & $\begin{array}{l}\text { Ens.Superior } \\
\text { Incompleto }\end{array}$ & $\begin{array}{l}\text { Agente de } \\
\text { Reflorestamento }\end{array}$ & 23 anos & $\begin{array}{l}\text { Semi } \\
\text { Aberto }\end{array}$ & 5 anos \\
\hline C & 52 & $\begin{array}{l}\text { Ensino Médio } \\
\text { Completo }\end{array}$ & Galvanoplasta & 27 anos & $\begin{array}{l}\text { Semi } \\
\text { Aberto }\end{array}$ & 10 meses \\
\hline
\end{tabular}

O Entrevistado A, iniciou na RAESP há seis meses, através do convite de uma assistente social, que o assistiu em uma das instituições que compõem a rede. Ficou 17 anos preso, após reincidir por 5 vezes. Relata que se tivesse oportunidade das outras vezes, não precisaria ter voltado tantas vezes para o cárcere.

Quando conheceu a RAESP, tinha o ensino fundamental incompleto, 6 ano; faltavam os documentos civis e estava desempregado. Durante seis meses, tirou todos os documentos, orientado pelo serviço social e foi encaminhado para o Centro de Referência em Educação de Jovens e Adultos - CREJA/ Prefeitura 
Municipal do Rio de Janeiro, para aumento de escolaridade e para curso de capacitação profissional.

Logo que concluiu o curso de capacitação, foi encaminhado para oportunidade de emprego. Está trabalhando formalmente e cursando o Ensino Médio, na modalidade de Educação para Jovens e Adultos - EJA, em um colégio Estadual.

O Entrevistado B, participa da RAESP há 5 anos, sua inserção também foi através do convite da assistente social, onde fazia um curso de formação. Ficou 23 anos presos. Há 5 anos trabalha como agente de reflorestamento, em um projeto de uma empresa pública. Foi encaminhado pelo serviço social, de uma das instituições que compõem a rede, para o Pré-vestibular social da PUC-Rio, para se capacitar, para prestar o vestibular das faculdades públicas e privadas, com bolsa de estudos. Deseja concluir a faculdade de direito e se especializar em Direito Ambiental. Atualmente, foi convidado, pela Pastoral Universitária da PUC, para participar do grupo de estudos em Direito Ambiental, pelo departamento.

Já o Entrevistado C, soube da existência da rede, através de um interno do sistema penitenciário. Ficou 27 anos preso. Há 10 meses participa das reuniões como membro individual. Faz parte de um grupo de teatro formado por internos e egressos, e estão concorrendo esse ano, ao Prêmio In Novare, na categoria Justiça e Cidadania. O entrevistado passou no vestibular para uma faculdade pública, mais de 10 vezes. Porém não consegue autorização do Juiz para frequentar as aulas. Atualmente trabalha no Projeto de inserção social, em uma empresa pública e tem o sonho de um dia ser um ator reconhecido e viver da sua arte.

Perguntas realizadas aos entrevistados:

\section{O que entende por Rede?}

"É a parceria de pessoas, órgãos e instituições com objetivos, filosofias $e$ finalidades similares". (Entrevistado A.)

"É um mecanismo que as pessoas trocam informações e consolidam ideias entre si." (Entrevistado B.)

“A união de todos, em prol de um objetivo comum!" (Entrevistado C.) 


\title{
Em sua opinião, qual a relação das Políticas Públicas com as Redes Sociais?
}

\begin{abstract}
"Posso perceber uma ausência e omissão por parte do estado em relação às políticas sociais, dando lugar assim a redes, movimentos e organizações que de alguma maneira faz o papel do estado. Percebo também alguns gestores de determinados setores do serviço publico que tem se empenhado para mudar o quadro presente do sistema social, mas definitivamente não há uma política efetiva $e$ sim o desempenho de pessoas, que lutam sem apoio de seus respectivos equipamentos". (Entrevistado A.)
\end{abstract}

"Buscam conhecimento (dados) em prol do aprimoramento de objetivos." (Entrevistado B.)

"As redes sociais começam a serem usadas como forma do cidadão ter sua voz ouvida e estabelecer um diálogo onde possa exercer pressão para que as políticas públicas sejam mais eficientes e transparentes nas ações implantadas". (Entrevistado C.)

\section{Qual o papel da Rede de Apoio ao Egresso, na vida dos usuários e para a}

\section{Sociedade?}

"Temos na rede, a solução dos problemas na vida dos que não tem oportunidade, $e$ dos excluídos. E quanto a sociedade, é beneficiada com a inserção de novos cidadãos que outrora foram excluídos, uns por causa da miséria, outros por causa da inversão de valores provocada pela má qualidade da educação ou ausência dela." (Entrevistado A.)

"Tem como finalidade mostrar aos individuos o caminho para buscar uma vida digna (promoção de Direito) e políticas públicas do interesse da sociedade." (Entrevistado B.)

"Na vida dos egressos: Ampara-los e encaminha-los a cursos profissionalizantes $e$ a parceiros que ofereçam trabalho e os conscientizar da importância da educação como forma de inclusão social e criar meios de dialogar com o poder Judiciário afim de que o mesmo analise com mais rapidez as petições dos internos do sistema semiaberto que almejam trabalhar ou que estão matriculados nas instituições de ensino profissionais, escolas e universidades".

Para a sociedade: Contribuir para diminuir a reincidência no crime e assim reduzir a violência na sociedade. (Entrevistado $C$.)

\section{Qual a importância da RAESP na condição de rede a egressos?}

“A RAESP é uma rede de instituições a ser reconhecida pelo poder público e ganhar notoriedade. Mas no silêncio onera ações efetivas para dar estrutura ao egresso do sistema penitenciário. Pessoas são alcançadas, e transformadas a partir das iniciativas da rede e sua teia." (Entrevistado A.) 
"Permite a sociedade a interagirem construindo condições participativas referentes à dignidade da pessoa humana. Essa estrutura em funcionamento no Estado do Rio de Janeiro é composta por pessoas que trazem em seu íntimo a preocupação com a valorização do ser humano. Estas pessoas possuem pensamentos nobres e sinceros e estes conteúdos permitem o excelente acompanhamento de Egresso pela Rede, permitindo a interação entre pessoas e instituições diversas, viabilizando o retorno do indivíduo à sociedade, apto a pensar em um projeto de vida digna." (Entrevista B.)

"Unir em si entidades e pessoas que promovem ações dentro e fora do sistema penitenciário e que em função disso, perceberam a necessidade de promoverem ações de amparo aos egressos, que em sua maioria saem do sistema desqualificados para o mercado de trabalho." (Entrevistado C.)

Diante das respostas apresentadas por dois internos e um egresso do sistema penitenciário, aqui representando um universo expressivo, de homens e mulheres que cumprem ou cumpriram penas privativas de liberdade, podemos observar que a prestação de assistência ao liberado da justiça, é um trabalho complementar ao desenvolvido na Instituição penitenciária.

Através desta assistência, este egresso (a) possui meios de subsistência e amparo social para se reintegrar ao convívio em sociedade. Para que ocorra de fato a inserção social, é necessário um trabalho em conjunto com todas as esferas da sociedade, quer seja pública, privada ou iniciativas de terceiro setor. É necessário que haja uma transformação do posicionamento da sociedade em relação ao preso e ao egresso que dificilmente são reconhecidos como indivíduos de direitos. É necessário também que se efetivem políticas públicas voltadas para este segmento, bem como a ampliação dessas políticas.

Costa (2012) afirma que:

Outro problema que atinge a raiz do sistema prisional do Rio de Janeiro é a escassez de política pública penitenciária no sentido de reduzir ou prevenir a reincidência ao crime e a violência, a estigmatização do indivíduo que cumpre ou já cumpriu pena, inclusive políticas públicas direcionadas para o atendimento dos egressos prisionais e seus familiares. (Costa, 2012, p. 7-8)

A inserção social, somente acontecerá se houver ações integradas. Sem a mudança de posicionamento da sociedade, dificilmente os egressos serão reconhecidos como homens e mulheres portadores de direitos e da vida em coletividade. É cogente também que haja uma transformação na conjuntura 
socioeconômica do país, criação de políticas públicas a fim de reduzir a discriminação e a desigualdade social.

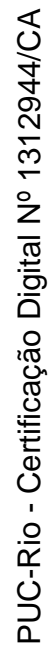




\section{5 \\ Considerações Finais}

Finalizando as considerações desse estudo, observamos que é através do nascimento do modelo de Estado do bem-estar social, que fez surgir o então Welfarismo Penal, política criminal fundamentada na reabilitação através da utilização da prisão, guiando-se através do modelo do Welfare State, no desempenho do Estado e de seus organismos de controle social na gerência de toda a sociedade, e da criminalidade.

Após seu período de crise, surgiram novas formulações do Estado assim como na esfera penal, através da mudança do Welfarismo para o então Estado Penal, neste momento é decretada a falência do ideal de "reabilitação" e do uso habitual à prisão, trocando e estendendo seu uso como mecanismo de controle social dirigido às categorias excluídas do sistema econômico. Esses fatores refletem sobre as circunstâncias do Estado brasileiro no que diz respeito à sua configuração, estrutura e modelos em termos de políticas públicas, social e criminal. Nos anos 80, o Brasil procura sua inserção nos moldes criminais do Welfarismo Penal, através da oficialização da Lei de Execução Penal (LEP), em 1984, que foi promulgada com a finalidade de aliar os preceitos internacionais de proteção aos direitos.

Promovendo a passagem do Estado Providência para o Estado Penal. Autoridades políticas priorizam a repressão e controle social ao invés de políticas públicas de cunho social. Outrora, no Brasil, se centrava no medo do escravo negro de tomar o poder. Agora, dirige-se ao medo do negro pobre, do excluído da sociedade de consumo. Como constata Wacquant, com a criminalização das consequências da pobreza.

Em todo o Brasil existe um "culto" a privação da liberdade e é quase somente voltada para os sujeitos que praticam delitos e que tem uma inserção de classe econômica pobre. Uma temática em que toda a sociedade precisa refletir, uma vez que todos estão, seja direta ou indiretamente, envolvidos na questão.

A questão social deriva das características assumidas pelos modos de produção que se estabeleceram em cada sociedade. É fruto das desigualdades e 
injustiças originadas pelas relações sociais e se expressa principalmente pela concentração de poder e de riqueza.

As mudanças no mundo do trabalho como a passagem do feudalismo para o capitalismo mercantil, da vida no campo para a forçada vida urbana, o exército industrial de reserva, a passagem do fordismo à acumulação flexível, foram fatores que aumentaram a pobreza.

A questão só foi levantada quando a sociedade alcançou consciência de classe, originada através dos problemas sociais decorrentes também do mundo do trabalho e da pauperização como fenômeno social. Esses fatos trouxeram o aumento da criminalidade, e quem não se adequava aos modos capitalistas, estava à margem da sociedade. Surgem então as diversas expressões/ manifestações da questão social, sendo a criminalização da pobreza como uma delas.

A precarização das políticas públicas, em face da redução de recursos e atendimento ao mínimo social, faz com que cada vez mais seja realizado o complemento das demandas da população junto à sociedade civil, preenchendo assim as lacunas apresentadas pela política pública.

$\mathrm{O}$ enfrentamento entre a efetivação das políticas sociais e o Estado neoliberal, cria um fenômeno que se caracteriza pela transferência para o Poder Judiciário, a responsabilidade de promover o enfrentamento à questão social, na perspectiva de efetivação dos direitos humanos.

Compreendemos que o bem-estar da sociedade depende do bem-estar dos indivíduos que a compõem. E para atender as demandas dos egressos, é importante pensar em ações coletivas, com o objetivo de diminuir o hiato existente entre eles e o dever do Estado. Os mesmos têm sua questão social particular, se pensado em termos do que ela representa como expressão especifica de luta por direitos sociais na sociedade moderna.

No caso do atendimento ao egresso, os recursos e a política desenvolvida a nível nacional e estadual, não atendem aos egressos na sua totalidade. Desta forma a sociedade civil organizada encontra formas de atender estas demandas apresentadas pelos egressos, através da Rede e das instituições que a compõe.

As instituições de cunho religioso são as primeiras a se manifestar em face do trabalho religioso ser realizado nas unidades prisionais desde o início do encarceramento, no regime fechado, e vai se desdobrando para os demais regimes. Temos ainda as instituições governamentais, que mesmo estando inseridas na 
política, participam da rede através dos seus técnicos, orientando possíveis encaminhamentos, frente ao seu conhecimento institucional.

Outro segmento representativo são organizações não governamentais criadas por egressos para atendê-los, criando assim um vínculo de legitimidade em face da origem dos seus fundadores.

Temos também segmentos advindos das universidades, com atuação junto aos egressos e que desenvolvem um pensamento crítico e propositivo à política pública.

Vale ressaltar que a política pública desenvolvida diretamente pelo Estado não atinge totalmente seus objetivos institucionais, porém, indiretamente, através de Conselhos e Fundos Especiais, direcionam recursos às instituições não governamentais para complementar suas ações. Neste sentido os parceiros da Rede Social, podem ser cada vez mais solicitados, a fim de complementar ou mesmo substituir o papel do Estado.

Neste modelo o Estado, executor direto das políticas públicas, aos poucos passa este papel para as redes sociais, muitas vezes sem controle dos seus resultados, sem levar em conta os critérios de eficiência, eficácia e efetividades, preconizados pela gestão pública nas ações.

Em um país com 607 mil presos e com a taxa de reincidência em torno de 80\% (Dados do relatório do Infopen - DEPEN, 2014) é necessário uma transformação do posicionamento da sociedade em relação ao preso e ao egresso que dificilmente são reconhecidos como indivíduos de direitos. É necessário também que haja efetivação de fato das políticas públicas voltadas para este segmento, bem como a ampliação dessas políticas.

A partir da atuação da sociedade civil, dos poderes públicos, entidades privadas e organizações do terceiro setor, os programas de apoio ao egresso do sistema penitenciário propõem-se à inserção social e a redução de índices de reincidência.

A inserção social é um processo árduo, pois apesar de existirem dispositivos legais que a garanta, poucas instituições realizam de fato um trabalho com tal perspectiva, para este segmento da sociedade.

Uma vez ouvi de um egresso, que $80 \%$ dos presos no Rio de Janeiro, querem uma oportunidade na vida. E que talvez se as tivessem, antes de serem presos, as chances de teriam cometido delitos seriam mínimas. 
Como resultado, verificou-se que em decorrência da estruturação do sistema penitenciário, que não promove a inserção social do egresso, é que se instala uma imensa demanda de egressos, completamente despreparados para reorganizar suas vidas. E que não existe ninguém incapaz de mudar, existem sim, métodos inadequados.

Assim, pode-se considerar que o estudo colabora para constatação de que não existe uma política pública nacional efetiva de atendimento ao egresso, o que faz com que a ação da rede socioassistencial, seja responsabilizada pela resolução de demandas apresentadas e a promoção da dignidade deste segmento de usuários.

Esse Estudo tentou mostrar o importante papel da rede de apoio, como resposta as demandas por legislações atualizadas e políticas públicas específicas. Que promovam conhecimento, estabilidade econômica, satisfação e desenvolvimento pessoal e a valorização do indivíduo.

Em um o universo de negação constante dos direitos, onde a própria sociedade clama pela redução dos direitos oferecidos às pessoas privadas de liberdade, a própria atuação da RAESP é um avanço na luta por justiça social.

Como propostas para trabalhos futuros, surgem as seguintes indagações: Como acontece a articulação das instituições que compõem a Rede de Apoio ao Egresso do Sistema Penitenciário - RAESP? E como é feita a avaliação dos resultados dessa Rede? Tema complexo e contemporâneo, tornado necessário, mais tempo para aprofundá-lo. 


\section{6 \\ Referências Bibliográficas}

ABRANCHES, S. H. Política social e combate a pobreza: a teoria da pratica. In: ABRANCHES, S. H.; SANTOS, W. G.; COIMBRA, M. A. Política social e combate a pobreza. Rio de Janeiro: Jorge Zahar Editor, 1987.

AGÊNCIA BRASIL. Estados com menores contingentes de trabalhadores no sistema penitenciário brasileiro. Disponível em: <http://agenciabrasil.ebc.com.br>. Acesso em 30 abr. 2015.

AMARAL, V. Rede: uma abordagem operativa. Disponível em: <http://www.portaldoenvelhecimento.net/artigos/artigo2287.htm>. Acesso em:

AQUIN, N. El Trabajo Social en la institucionalidad de las políticas públicas. Comprender los limites, potenciar las possibilidades. In: AQUIN, N.; CARO, R. (Orgs.). Políticas Públicas, derechos y Trabajo Social en el Mercosul. Buenos Aires: Espacio Editorial, 2009, p.151-166.

BOBBIO, N. A Era dos direitos. Rio de Janeiro: Elsevier, 2004, p. 60.

Ensaios sobre Gramsci e o conceito de sociedade civil. São Paulo: Paz e Terra, 1999.

BORGIANNI, E. Ética e direitos humanos na sociedade e no Serviço Social. In: CRESS/7 Região (Org.). Em foco: O Serviço Social e o sistema sociojuridico. Rio de Janeiro: CRESS / 7Região; PPGSS/UERJ, n. 2, 2004.

BRASIL. Constituição (1988). Constituição da República Federativa do Brasil, Brasília, DF, Senado, 1988.

. Lei de Execução Penal. Lei № 7.210, de 11 de Julho de 1984.

. Política Nacional de Assistência Social - PNAS. Brasília, 2004.

1993.

Lei Orgânica de Assistência Social. Lei no 8.742, de 7 de Dezembro de

Conceituação e classificação dos estabelecimentos penais. Disponível em: <http: //www.brasil.gov.br - Portal ou http://portal.mj.gov.br>. Acesso em 27 jun. 2015. 
BRAVO, M. I. S; PEREIRA, P. A. P. Política Social e Democracia. Cortez, 5. Ed., 2012.

CAMPOS, M. S. Assistente Social: confidente, juiz, bombeiro, agitador social. Guardião da humanidade em qualquer tempo? Serviço Social: questões políticas, sociais, metodológicas, PUC/SP, s/n 1988.

CARLOS, E. Contribuições da análise de redes sociais às teorias de movimentos sociais. Rev. Sociol. Polít. Curitiba. v. 19, n. 39, p. 153-166. Jun. 2011.

CARVAlHO, J. M. Cidadania no Brasil - o longo caminho. Editora Civilização Brasileira - 18. Ed., 2014.

CASTEL R. A insegurança social: o que é ser protegido? Petrópolis: Vozes, 2005, P 31

CASTELLS, M. A Era da Informação: economia, sociedade e cultura: a sociedade em rede. São Paulo: Paz e Terra, 1999.

COSTA, N. Sistema prisional do Rio de Janeiro, punitivo e controlador. VII CONGRESSO PORTUGUÊS DE SOCIOLOGIA, 2012.

COUTO, B. R et. al. (Orgs). O Sistema Único de Assistência Social no Brasil: uma realidade em movimento. São Paulo: Cortez, 2010, p. 139-182.

O Direito Social e a Assistência Social na Sociedade Brasileira: uma equação possível? 3. ed. São Paulo: Cortez, 2008.

DUARTE, R. Entrevistas em pesquisas qualitativas. Educar, n.24, 2004, p.213225.

ECO, U. Como se faz uma tese, SP: Perspectiva, 2010, p.87-113.

FAGHERAZZI, Dr. Irmão João Orestes. Cuadernos de la cárcel. Buenos Aires: edición especial de Nohay Derecho, 1991.

FALEIROS, V. Infância e processo político no Brasil. In: PILOTTI, F.; RIZZINI, I. A arte de governar crianças: a historia das políticas sociais, da legislação e da assistência no Brasil. Rio de Janeiro: AMAIS, 1995.

FLEURY, S.; OUVERNEY, A. M. Gestão de Redes: a estratégia de regionalização da política de saúde. Rio de Janeiro: FGV, 2007.

FONSECA, K. H. C.; KAMIMURA, Q. P. O perfil de egressos do sistema penitenciário numa central de atendimento ao egresso e familiar na região do Vale do Paraíba. São Paulo, 2010. 
FORTI, V. L. Ética e Serviço Social. Caderno Especial, n. 27, nov / dez, 2005. Disponível em: <www.assistentesocial.com.br>. Acesso em 30 jul. 2015.

FOUCAULT, M. Vigiar e punir: nascimento da prisão. Petrópolis, Vozes, 1987.

FRAGILE FAMILIES RESEARCH BRIEF. Parental Incarceration and Child Wellbeing in Fragile Families, n. 42, abr. 2008. Disponível em: $\langle$ http://www.fragilefamilies.princeton.edu/briefs/ResearchBrief42.pdf $>$. Acesso em 13 jul. 2015.

FREIRE, Paulo. Extensão ou comunicação? 8. ed., Rio de Janeiro: Paz e Terra, 1985.

FUNDAÇÃO SANTA CABRINI. O objetivo do trabalho desenvolvido pela Fundação Santa Cabrini, com os presos no Rio de Janeiro. Disponível em: <http://www.santacabrini.rj.gov.br>. Acesso em 10 jul. 2015.

GIL. A. C. Como elaborar projetos de pesquisa. 4. ed., São Paulo: Atlas, 2004.

GOFFMAN, E. Estigma: notas sobre a manipulação da identidade deteriorada. Rio de Janeiro. Zahar Editoras, 1975.

GRAMSCI, A. Maquiavel, a política e o Estado moderno. Tradução de Luiz Mário Gazzaneo. Rio de Janeiro: Civilização Brasileira, 1968.

IAMAMOTO, M. V. O Serviço Social na cena contemporânea. In: Serviço Social: Direitos Sociais e Competências Profissionais. Brasília: CFESS/ABEPSS, 2009, p. 1-46.

ILANUD - Instituto Latino Americano das Nações Unidas para Prevenção do Delito e Tratamento do Delinquente. Avaliação do atendimento à população egressa do sistema penitenciário do Estado de São Paulo. ILANUD / Brasil e DEPEN. 2003.

JACCOUD, L. B. Proteção Social no Brasil: debates e desafios. In: Concepção e Gestão da Proteção Social não contributiva no Brasil. Brasília: MDS/UNESCO, 2009.

JUNQUEIRA, L. A. P. Organizações sem fins lucrativos e redes na gestão de políticas sociais. Caderno de Administração, PUC-SP, N. 3, 2000, p. 101-126. Intersetorialidade, transetorialidade e redes sociais na saúde. Revista de Administração Pública - RAP, Rio de Janeiro, 34: 35-46, nov./dez.2000.

JUS NAVIGANDI. Disponível em:<http://jus.com.br> Acesso em: 03 maio 2015. 
LEIRAS, M.; NASCIMENTO, T.; TAVARES, M. A. S. As Potencialidades do Egresso do Sistema Penitenciário: para além do mercado, a formação para a vida. Rio de Janeiro, Banco da Providência, PETRES-UERJ - 2013.

MADEIRA, L. M. A atuação da sociedade civil na ressocialização de egressos do sistema penitenciário. VII CONGRESSO LUSO-AFRO-BRASILEIRO DE CIÊNCIAS SOCIAIS. Coimbra, Portugal, 2004.

Trajetória de homens infames: Políticas Públicas Penais e Programas de apoio a Egressos do Sistema Penitenciário no Brasil. Porto Alegre, dez. 2008.

MARX, K.; ENGELS, F. A ideologia alemã. São Paulo: Moraes, 1984, p.14.

MENICUCCI, T. M. G. Intersetorialidade, o desafio atual para as políticas sociais. Pensar BH/Política Social. Belo Horizonte: Prefeitura, n. 3, 2002, p. 1013.

MINAYO, M. C. de S. O desafio do conhecimento: pesquisa qualitativa em saúde. 7. ed., São Paulo: Hucitec; Rio de Janeiro: Abrasco, 2000.

MINAYO, M. C. S. Ciência, Técnica e Arte: o desafio da pesquisa social In: 2004, p. 9-29. (Org.) Teoria, Método e Criatividade. 23. ed., Petrópolis, RJ: Vozes,

MIOTO, R. C. Orientação e acompanhamento social a indivíduos, grupos e famílias. In: CFESS. (Org.) Serviço Social: Direitos Sociais e Competências Profissionais. Brasília: CFESS/ABEPSS, 2009, p.37.

MOTA, A. E. (Org.). O mito da assistência social: ensaios sobre Estado, política e sociedade. 2. ed. rev. e ampliada. São Paulo: Cortez, 2013. P. 105 - 128.

NETTO, J. P. Pobreza, "questão social" e seu enfrentamento. (2001) Serv. Soc. Soc., São Paulo, n. 110, abr. p. 42, jun. 2012.

O GLOBO. Relato do Ministro da Justiça, José Eduardo Cardozo, sobre as condições das cadeias no Brasil. Disponível em: <http://oglobo.globo.com>. Acesso em 15 jun. 2015.

OLIVEIRA, O. M. Prisão: Um Paradoxo Social. Florianópolis: Ed da UFSC, 1996.

PEREIRA, C. A Política Pública como Caixa de Pandora: organização de interesses, processo decisório e efeitos perversos na Reforma Sanitária Brasileira 1985-1989. Dados, v.39, n. 3, 1996. 
PRAXIS. Revista do conselho regional de serviço social/RJ a. 7, n. 81, p. 39, jan./fev. 2015.

RIO DE JANEIRO. (Estado). Missão e objetivos da Secretaria de Estado e Administração Penitenciária do Rio de Janeiro. Disponível em: <http://www.rj.gov.br/web/seap>. Acesso em 30 abr. 2015.

SANTOS, W. G. Cidadania e justiça: a política social na ordem brasileira. Rio de Janeiro: Ed. Campus, 1979.

Crise e Castigo. Rio de Janeiro: Vértice, 1987.

SCHERER-WARREN, I. Cidadania sem fronteiras: ações coletivas na era da globalização. São Paulo: Hucitec, 1999.

Redes e sociedade civil global. In: HADDAD, S. (Org.). ONGs e universidades: desafios para a cooperação na América Latina. São Paulo: Abong; Petrópolis, 2002, p. 63-92.

Redes sociais: trajetórias e fronteiras. In: DIAS, L. C.; SILVEIRA, Rogério L. L. (Orgs.). Redes, sociedade e território. Santa Cruz do Sul: EDUNISC, 2005.

SILVEIRA, D. T.; CÓRDOVA, F. P. A pesquisa científica In: GERHARDT, T. E.; SILVEIRA, D. T. (Orgs.). Métodos de pesquisa. Porto Alegre: UFRGS, 2009.

SIQUEIRA, J. R. O trabalho e a assistência social na reintegração do preso à sociedade. Serviço Social \& Sociedade, n. 67, 2001.

SOARES, L. T. O desastre social (Os porquês da desordem mundial. Mestres explicam a globalização). Rio de Janeiro: Record, 2003.

SPOSATI, A. Políticas Sociais e Assistência Social. In: Debates Sociais Exclusão Social - Novas e velhas formas. Rio de Janeiro: CBCISS, 2001, p. 133-140.

Pobreza e desigualdade no século do desperdício In: Inclusão social: Enfrentamento da Pobreza e das Desigualdades Sociais - XXXII CONFERENNCIA INTERNACIONAL DE BEM-ESTAR SOCIAL. CBCISS, Brasília, 16 a 20 de julho de 2006.

STOER, S. R. Os lugares da exclusão social: um dispositivo de diferenciação pedagógica. São Paulo: Cortez, 2004. 
TATAGIBA, L. Os conselhos gestores e a democratização das políticas públicas no Brasil. In: DAGNINO, E. (Org.). Sociedade civil e espaços públicos no Brasil. São Paulo: Paz e Terra, 2002.

TEIXEIRA, S. M. F. O desafio da gestão das redes de políticas. VII CONGRESSO INTERNACIONAL DEL CLAD SOBRE LA REFORMA DEL ESTADO Y DE LA ADMINISTRACIÓN PÚBLICA, Lisboa, Portugal, out. 2002, p. 8-11.

WAQUANT, L. As prisões da miséria. Rio de Janeiro: Zahar, 2001.

WERNECK, M. L. T. V. "Seguridade Social e Combate à Pobreza no Brasil: o papel dos benefícios não contributivos". In: VIANA, A. L.; ELIAS, P.; IBAÑEZ, N. (Orgs.). Proteção Social: Dilemas e Desafios. São Paulo, 2004.

WHITAKER, F. Rede: uma estrutura alternativa de organização. Disponível em: $<$ http//www.inforum.insite.com.br/arquivos/2591/estrutura_alternativa_organizac ao.PDF $\rightarrow$. 2007. Acesso em:

YAZBEK, M. C. Classes subalternas e assistência social. 2. ed., São Paulo: Cortez, 1996. 
Anexos

7.1.

Anexo 1 - Questionário de Pesquisa: Rede de Apoio ao Egresso do Sistema Penitenciário - RAESP

\section{1) Apresentação Institucional:}

Nome da Instituição:

Natureza:

Ano de Fundação:

Representante Legal:

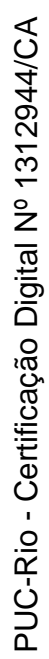

Área de atuação:

Público alvo:

Serviços ofertados:

\section{2) Dados Institucionais:}

Endereço:

Telefones:

Email:

Cargo ou função do entrevistado:

\section{3) Perfil dos Beneficiários:}

Quantitativo de usuários atendidos pela instituição:

Origem do Público atendido:

( ) Demanda espontânea

( ) Encaminhados. Quais instituições que mais encaminham?

Público predominante: ( ) Masculino ( ) Feminino ( ) Ambos 
Faixa Etária: ( )18 a $24 \quad$ ( )25 a $30 \quad$ ( )31 a $40 \quad$ ( )41 a $50 \quad$ ( )51 a 60

( ) Acima de 61 anos

\section{Escolaridade:}

( )Ensino Fundamental Incompleto ( ) Ensino Fundamental Completo

( ) Ensino Médio Incompleto ( ) Ensino Médio Completo ( ) Ensino Superior Incompleto

( ) Ensino Superior Completo

\section{Motivo de inserção no sistema prisional:}

Quais os artigos/delitos mais frequentes?

( ) 33 -tráfico ( ) 121 - homicídio ( ) 155 - furto ( ) 157 - assalto ( ) 213

Estupro ( ) 171 - estelionato （ ) outros. Quais?

\section{Média de tempo, dos egressos assistidos, no sistema penitenciário:}

( ) menos de 1 ano ( ) 1 a $3 \operatorname{anos}$ ( ) 4 a $6 \operatorname{anos}$ ( ) 7 a $10 \operatorname{anos}$ ( ) 11 a 15 anos

( ) 16 a $20 \operatorname{anos}$ ( ) acima de 21 anos

\section{Principais Demandas dos atendidos:}

( ) Documentação

( ) Capacitação

( )Trabalho

( ) Aumento de Escolaridade

( ) Cesta básica

( ) Atendimento Jurídico

( ) Atendimento de Saúde

( ) Atendimento Psicológico

( ) Outros:

Quais as principais demandas viabilizadas/encaminhadas e atendidas? 


\section{4) Entendimento de Rede/Parceria:}

$\mathrm{O}$ que entende por rede?

Em sua opinião, qual a relação das Políticas Públicas com as Redes Socias?

Qual é o papel da Rede de Apoio ao Egresso, na vida dos usuários e para a Sociedade Brasileira?

\section{Tempo de participação na RAESP:}

Qual a importância da RAESP na condição de rede a egressos?

Qual o objetivo da instituição em participar da Rede:

Considera que a RAESP alcança seus objetivos? De que forma/Por quê? 
Quais os principais resultados da RAESP?

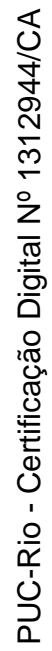




\section{2. \\ Anexo 2 - Ata de constituição da Rede de Apoio ao Egresso do Sistema Penitenciário}

No dia 19 (dezenove) de outubro de 2006, nas dependências do Banco da Providência, na Catedral Metropolitana do Rio de Janeiro, as entidades abaixo relacionadas e devidamente representadas por seus representantes abaixo assinados, eis que devidamente credenciados para tanto, como também os membros individuais, pessoas físicas no pleno exercício de sua capacidade jurídica, também abaixo-assinados e qualificados: como consequência do aprofundamento do tema referente ao egresso do Sistema Penitenciário do Estado do Rio de Janeiro em sucessivas outras reuniões já realizadas; como consequência da consciência individual e coletiva de que todos os cidadãos devem ser direta ou indiretamente, corresponsáveis pela recuperação e reintegração dos egressos do Sistema Penitenciário de qualquer país do mundo civilizado na sociedade que os puniu, DELIBERAM, por unanimidade, CRIAR e iniciar a IMPLANTAÇÃO da REDE DE APOIO AO EGRESSO DO SISTEMA PENITENCIÁRIO - RAESP, consistente, em síntese na união de ideias e ações concretas em busca da consecução permanente dos objetivos da REDE. Deliberou-se, ainda, que não será criada qualquer pessoa jurídica para a consecução dos objetivos da RAESP, tendo

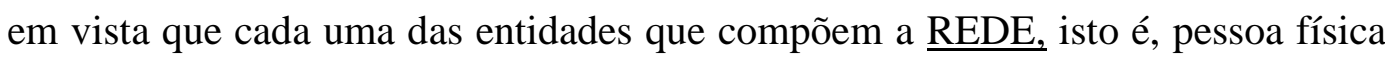
ou jurídica cumprirá as missões que lhes caibam por discussão solidária e democrática dos temas e ações em pauta.

Foi deliberado, ainda, que para alcançar os objetivos da RAESP, serão estabelecidas metodologias próprias para cada situação em especial como também outras, de caráter geral, destinadas a fortalecer e dinamizar a REDE para a consecução de seu objetivo central. Para operacionalização das ações da RAESP ficou decidido que haverá as seguintes instâncias: Assembleia Geral, $\underline{\text { Coordenação }}$ Colegiada e Grupos de Trabalho. A Assembleia Geral é o órgão de deliberação maior e final na estrutura da REDE e é composta pelas instituições que a integram através de dois representantes, um titular e um suplente, ambos com direito a voto, estando presentes. Cada membro individual participante da Assembleia Geral terá direito a um voto, sendo vedado o voto por procuração. A Assembleia Geral tem as seguintes atribuições: eleger o_colegiado (coordenação colegiada); deliberar 
sobre a inserção de instituições e membros individuais na REDE; discutir e decidir sobre os planos de ação da REDE (estratégicos e operacionais); definir ações concretas se preciso, em consonância com a VEP e/ou com a secretaria de administração Penitenciária do Estado do Rio de Janeiro. A coordenação colegiada é o órgão de operacionalização e monitoramento do desempenho das ações da REDE (RAESP). É formada pelos coordenadores dos grupos de trabalho, devendo reunir-se, no mínimo, quinzenalmente. O colegiado (coordenação colegiada) terá as seguintes atribuições: coordenar e monitorar as ações da REDE, conforme o Plano Estratégico definido em Assembleia Geral; deliberar sobre matéria que não seja da competência maior da Assembleia Geral; representar a REDE nas diversas instâncias governamentais ou sociedade civil, deliberando sobre questões que envolvam as atividades de que se ocupa a REDE. Os grupos de trabalho são definidos em Assembleia Geral, conforme as necessidades da REDE e serão compostos pelas instituições e membros individuais que fazem parte da mesma. A composição numérica de cada grupo de trabalho (GT), bem como possível especificidade de seus membros, será definida quando da formação de cada grupo. Em casos excepcionais, poderão integrar grupos de trabalho voluntários que por seus conhecimentos técnicos ou por razões fáticas especialíssimas sejam indispensáveis ou úteis ao bom termo do objetivo buscado pela REDE. Por último, foi deliberado que todas as decisões tomadas pelas instituições e membros individuais constantes da presente Ata Constitutiva da REDE terão força de um protocolo de intenções a ser respeitado e que entrará em vigor na data de sua assinatura, podendo ser desligado ou afastado da REDE, por decisão da Assembleia Geral, o membro que desrespeitar as normas ora estabelecidas ou omitir-se, reiteradamente, quanto as ações a serem desenvolvidas em busca dos objetivos que ensejaram a formação da RAESP. Assim, lida discutida e aprovada a presente ata constitutiva da RAESP, para todos os direitos e como prova de assim estarem acordados entre si, assinam as partes o presente instrumento, o qual, também por decisão unânime, será devidamente registrado em Cartório de Títulos e Documentos desta comarca.

Rio de Janeiro (RJ), 19 de outubro de 2006. 